Review

\title{
Bio-Based Aromatic Epoxy Monomers for Thermoset Materials
}

\author{
Feifei Ng, Guillaume Couture, Coralie Philippe, Bernard Boutevin and Sylvain Caillol * \\ Institut Charles Gerhardt-UMR 5253, CNRS, Université de Montpellier, ENSCM, 8 rue de l'Ecole Normale, \\ 34296 Montpellier, France; feifeing.fr@gmail.com (F.N.); Guillaume.couture@enscm.fr (G.C.); \\ coralie.philippe@enscm.fr (C.P.); bernard.boutevin@enscm.fr (B.B.) \\ * Correspondence: sylvain.caillol@enscm.fr; Tel./Fax: +330-467-144-327
}

Academic Editors: Thomas Farmer and James H. Clark

Received: 24 November 2016; Accepted: 10 January 2017; Published: 18 January 2017

\begin{abstract}
The synthesis of polymers from renewable resources is a burning issue that is actively investigated. Polyepoxide networks constitute a major class of thermosetting polymers and are extensively used as coatings, electronic materials, adhesives. Owing to their outstanding mechanical and electrical properties, chemical resistance, adhesion, and minimal shrinkage after curing, they are used in structural applications as well. Most of these thermosets are industrially manufactured from bisphenol A (BPA), a substance that was initially synthesized as a chemical estrogen. The awareness on BPA toxicity combined with the limited availability and volatile cost of fossil resources and the non-recyclability of thermosets implies necessary changes in the field of epoxy networks. Thus, substitution of BPA has witnessed an increasing number of studies both from the academic and industrial sides. This review proposes to give an overview of the reported aromatic multifunctional epoxide building blocks synthesized from biomass or from molecules that could be obtained from transformed biomass. After a reminder of the main glycidylation routes and mechanisms and the recent knowledge on BPA toxicity and legal issues, this review will provide a brief description of the main natural sources of aromatic molecules. The different epoxy prepolymers will then be organized from simple, mono-aromatic di-epoxy, to mono-aromatic poly-epoxy, to di-aromatic di-epoxy compounds, and finally to derivatives possessing numerous aromatic rings and epoxy groups.
\end{abstract}

Keywords: epoxidation; aromatic; epichlorohydrin; tannin; lignin; cardanol

\section{Introduction}

Amidst materials widely used in plastic industry nowadays, thermosets (or thermosetting polymers) represent about $20 \%$ of plastic production [1]. They are formed from a liquid or solid mixture of various ingredients including at least one or more monomers. One of these monomers at least exhibits a functionality equal or higher than three, thus enabling the creation of a solid three-dimensional non-fusible network via an external action such as heating or UV irradiation [2]. Thermosets include a wide range of reactive systems such as phenolic and urea formaldehyde resins, unsaturated polyesters, and polyepoxides, the latter accounting for nearly $70 \%$ of the market. Polyepoxides are one of the most versatile class of compounds with diverse applications, especially coatings, which dominate the market, but also water containers, automotive primer, printed circuit boards, semiconductor capsules, adhesives, and aerospace composites. The global production of epoxy prepolymers is estimated to reach 3 million tons by 2017 for a market of US $\$ 20$ billion in 2015. This success arises from the excellent mechanical strength and toughness, outstanding chemical, moisture, and corrosion resistance of the epoxy thermosets [3,4]. This list does not include various interesting process-related characteristics such as: the absence of volatile products emitted during the 
polymerization reaction, the large choice of monomers available or the high adhesion properties to a variety of surfaces.

Over $90 \%$ of these epoxy materials are based on bis(4-hydroxyphenylene)-2,2-propane, known as bisphenol A (BPA), a petrol-based molecule first synthesized in the 1890s and used as a synthetic oestrogen [5]. Aromatic compounds are widely used in organic materials for their stability, their toughness, and above all their ability to structure the matter by $\pi$-stacking, thus allowing BPA to confer good thermal and mechanical properties to the epoxy thermosets. Commercialized for more than 50 years, BPA, mainly through its epoxy form DiGlycidylEther of Bisphenol A (DGEBA), is nowadays spread in many coatings, adhesives, laminates and composites, but also many domestic or even health related-products such as plastic bags, food containers and metal cans, dental sealants, soaps and lotions [6,7].

However, epoxy thermosets are sensitive to hydrolysis, which may cause BPA to leach, leading to widespread human exposure [6-9]. Unfortunately, it has been classified as carcinogen mutagen and reprotoxic (CMR), and is recognized as an endocrine disruptor [10]. Consequently, many governments have recently hardened the legislation regarding the production and use of BPA, especially in baby's bottles, food containers and medical supplies [11,12]. Moreover, BPA is synthesized from oil-based phenol and the 3D chemically crosslinked networks of thermosets prevent them from being recycled by heating. The awareness on BPA toxicity combined with the limited availability and volatile cost of fossil resources, and the non-recyclability of thermosets implies necessary changes in the field of epoxy networks. Thus, substitution of BPA has witnessed an increasing number of studies both from the academic and industrial sides. Over the past decades, many bio-based resources have been tested as potential candidates for replacing BPA in epoxy resins, but very few of them have reached the commercialization step. Among these, epoxidized natural oils [13-15] and modified cardanol [16] are the only two types of epoxy resins based on natural and non-toxic precursors, commercially available in the market. However, the low reactivity of the epoxy groups along their aliphatic backbone [1] and the low glass transition temperature caused by the alkyl chain prevent them from competing with BPA-based materials with their high $T_{\mathrm{g}}$ values and glassy moduli [17]. For this reason, many researches have been devoted to using glycidylated aromatic bio-based materials as substitutes for BPA. Very interesting and exhaustive reviews have recently been published on bio-based precursors for thermosets and their hardeners [1,18-21], but to our knowledge, none of them focuses especially on aromatic epoxy monomers based on biomass resources. In fact, only aromatic poly-epoxides seem to be able to compete with DGEBA in terms of thermo-mechanical properties, making them of primary interest for renewability.

Thus, the present review proposes to give an overview of the reported aromatic multifunctional epoxide building blocks synthesized from biomass or from molecules that could be obtained from transformed biomass. After a reminder of the main glycidylation routes and mechanisms and the recent knowledge on BPA toxicity and legal issues, this review will provide a brief description of the main natural sources of aromatic molecules. The different epoxy prepolymers will then be organized from simple, mono-aromatic di-epoxy, to mono-aromatic poly-epoxy, to di-aromatic di-epoxy compounds, and finally to derivatives possessing numerous aromatic rings and epoxy groups. For each one, the curing agent used and the thermal properties (especially $T_{\mathrm{g}}$ and thermal degradation) of the crosslinked material will be given along with their DGEBA-based counterparts if available. The potential toxicity of the epoxy precursors will also be mentioned. Tables gathering all these results will be given at the end of each part for comparative purposes.

\section{Epoxidation Methods and Processes}

Poly-functional epoxy compounds are very reactive building blocks and can lead to materials by chain-growth polymerization or crosslinking with anhydrides, phenols and amines. They are generally prepared by direct glycidylation, as showed in Scheme $1[1,22,23]$. It consists in reacting an alcohol or amine derivative with epichlorohydrin $(\mathrm{ECH})$ in the presence of an alkylammonium 
halide as a phase transfer catalyst, such as benzyltriethylammonium chloride, tetrabutylammonium bromide or cetyltrimethyl ammonium chloride. Sometimes, epibromohydrin is used instead of its chloride analogue [24]. A sodium or potassium hydroxide post-treatment is usually applied in same pot to increase the number of epoxy rings. In fact, the phenolic oxygen may displace the chlorine atom to directly yield the desired product via a $\mathrm{S}_{\mathrm{N}} 2$ mechanism, or open the epoxy ring causing the formation of a chlorinated derivative that can be closed by a strong base through a $\mathrm{S}_{\mathrm{N}} \mathrm{i}$ mechanism (Scheme 2) $[25,26]$. $S_{N} i$ stands for Substitution Nucleophilic internal and is a nucleophilic substitution mechanism that implies a retention of configuration.
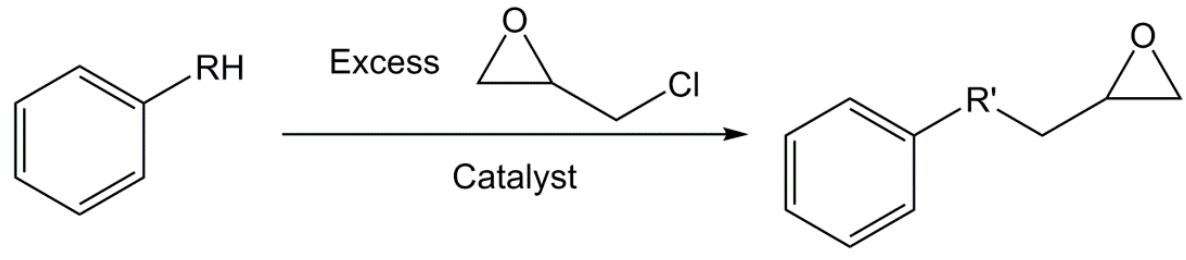

$$
\begin{aligned}
& \mathrm{R}=\mathrm{O} ; \mathrm{R}^{\prime}=\mathrm{O} \\
& \mathrm{R}=\mathrm{NH} ; \mathrm{R}^{\prime}=\mathrm{N}-\mathrm{CH}_{2} \text {-epoxy }
\end{aligned}
$$

Scheme 1. Synthesis of epoxy derivatives from phenol or aniline by direct glycidylation with epichlorohydrin.

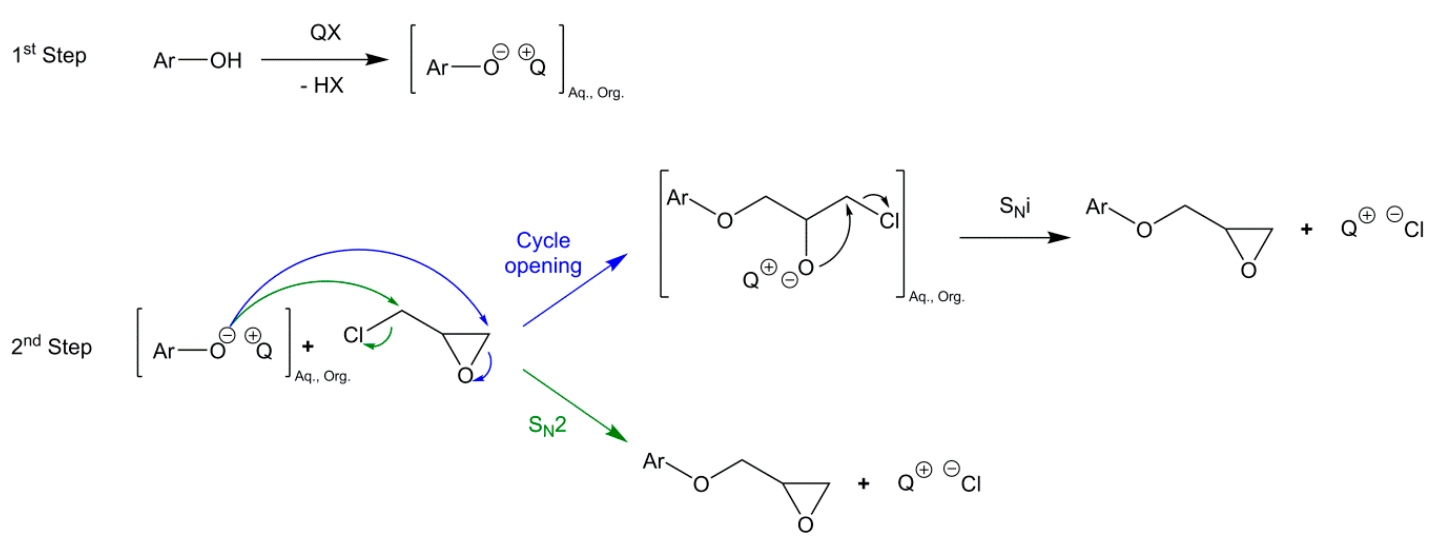

Scheme 2. Mechanism of coupling between phenolic compounds and epichlorohydrin (ECH) in the presence of a phase transfer catalyst (QX) [1,27].

The direct glycidylation of phenol has proven to yield several possible side products [28-32] including chlorinated and diol derivatives (Figure 1). Furthermore, the higher reactivity of benzoic acid may lead to an opening of the epoxy via both carbon atoms, leading to new chlorinated (B2), diol (B3) and oxetane ring (B1) side-products [33-37]. Another important side-product observed during the glycidylation step with epichlorohydrin is a benzodioxan derivative obtained by an intra cyclization occurring with two phenolic groups in ortho position (Scheme 3). 
<smiles>c1ccc(OCC2CO2)cc1</smiles>

(A1)<smiles>O=C(OC1COC1)c1ccccc1</smiles>

(B1)<smiles>OC(CCl)COc1ccccc1</smiles>

(A2)<smiles>O=C(OC(CO)CCl)c1ccccc1</smiles>

(B2)<smiles>OCC(O)COc1ccccc1</smiles>

(A3)<smiles>O=C(OC(CO)CO)c1ccccc1</smiles>

(B3)

Figure 1. Common side-products of the direct glycidylation of phenol (A1-A3) and benzoic acid (B1-B3).
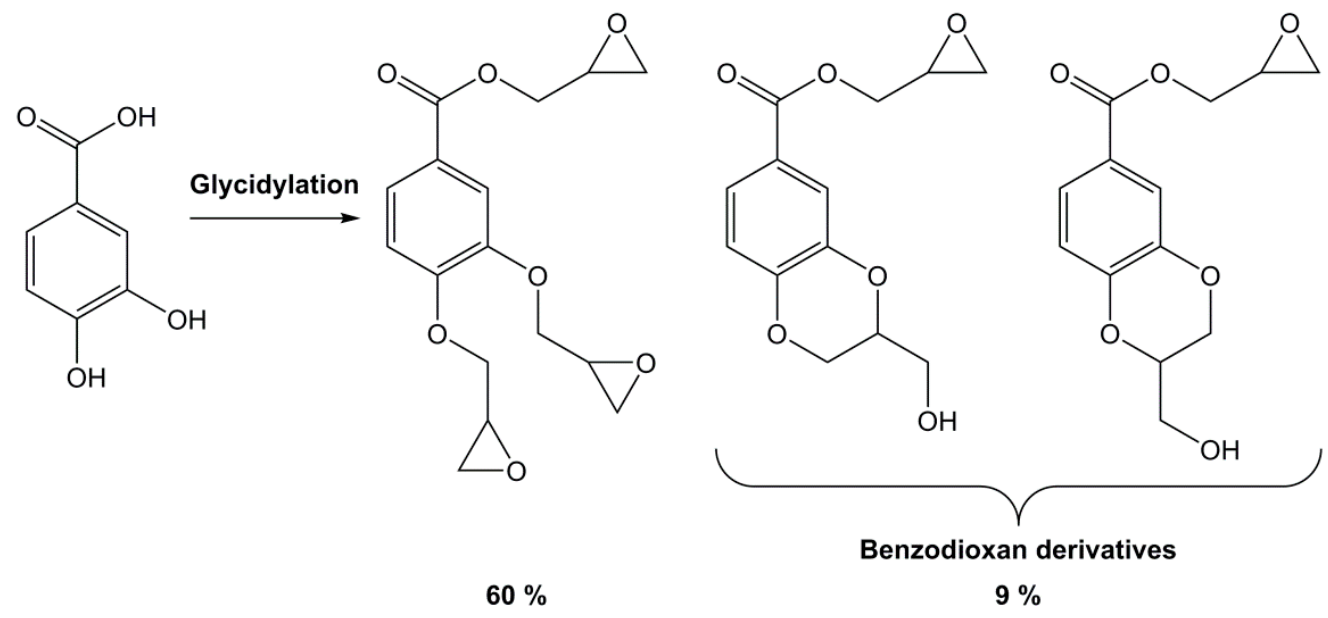

Scheme 3. Products obtained during the glycidylation of protocatechuic acid with epichlorohydrin [38].

To avoid these drawbacks, Meurs et al. [39] developed a process to obtain glycidyl derivatives from phenol, glycidol and propylene carbonate but it requires the use of high temperatures in autoclave and relatively harsh conditions. A two-step synthesis can also be used to form epoxy compounds: it involves the $\mathrm{O}$ - or $\mathrm{N}$-allylation of the corresponding alcohol or amine derivatives using an allyl halide, followed by the oxidation of the resulting double bond (Scheme 4). Unfortunately, allyl chloride and allyl bromide are both toxic derivatives. Moreover, hydrogen peroxide exhibitis low reactivity toward allyl ether oxidation except at high concentrations or in the presence of metal transition catalysts [40]. The use of stronger, more toxic peracids such as $m$-chloroperbenzoic acid ( $m$ CPBA) is sometimes considered, but Aouf et al. [22] found that an excess of peracid is also required and the $m$-chlorobenzoic acid formed during the oxidation of allylated gallic acid is difficult to eliminate. The epoxidation of allyl groups by potassium peroxymonosulfate (also known as Oxone) can be considered a sustainable pathway. It is based on the Shi epoxidation, which uses a fructose-derived organocatalyst with Oxone and ketones to generate in situ dioxiranes [41], which are strong epoxidation agents. However, the epoxidation of electron-deficient alkenes such as allyl groups by dioxiranes can be very slow [42-44]. The reaction may require the use of ketones bearing highly electroattractive groups such as 1,1,1-trifluoroacetone to increase the overall yield [22,45]. Enzymatic catalysts have also been developed as greener alternatives for the oxidation of carbon-carbon double-bonds. First developed to replace the Prileshajev reaction applied at an industrial scale to produce epoxy vegetable 
oils [46], one of these catalyst (immobilized lipase B from Candida antarctica (Novozym 435)) has also been used by Aouf et al. [40] to obtain epoxy gallic acid and vanillic acid from their allylated precursors in high yields.

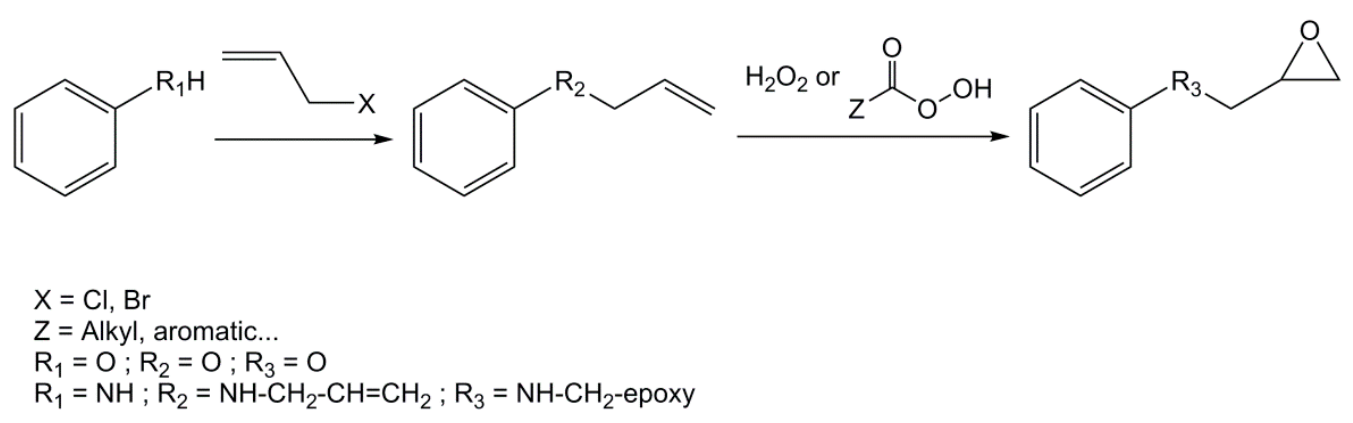

Scheme 4. Synthetic pathway to obtain epoxy from phenol or aniline using allyl halide and oxidation.

Overall, the direct glycidylation remains the main synthetic pathway used for the industrial synthesis of Diglycidyl Ether of Bisphenol A, as it allows the recovery of both monomers and oligomers for tunable properties [23,47]. By reacting bisphenol A with a controlled excess of epichlorohydrin, the "taffy" process yields either monomers or short oligomers of DGEBA (Scheme 5). To increase the chain length of the oligomers, "advancement" (with solvent) or "fusion" (without solvent) processes can be chosen. They both consist in reacting BPA with an excess of a pre-synthesized DGEBA monomer to extend the chain. "Fusion" process is generally preferred for the industrial production of DGEBA oligomers as the purification steps are easier and the chlorine content of the final product is lower than in the case of the "taffy" process, which requires an excess of epichlorohydrin.<smiles>CC(C)(C)C1CO1</smiles>

Scheme 5. Two main industrial processes for the synthesis of monomers and oligomers of diglycidyl ether of vanillyl alcohol (DGEBA): (i) the taffy process with a controlled excess of epichlorohydrin and (ii) the advancement/fusion process using an excess of a pre-synthesized DGEBA monomer.

In terms of sustainability, both bisphenol A and epichlorohydrin used for the synthesis of DGEBA are mostly oil-based. BPA is obtained from reaction of acetone and phenol and epichlorohydrin is synthesized in two steps by reacting hypochlorous acid on allyl chloride and then treating the alcohol mixture obtained with a strong base [48]. In 2007, Solvay designed the EPICEROL ${ }^{\mathrm{TM}}$ process to produce epichlorohydrin from bio-based glycerol, thus allowing to reduce the content of fossil resources used for DGEBA production [49-53]. However, the percentage of carbon atoms in the oligomers coming from ECH is low, thus making the impact limited. Furthermore, whatever synthetic pathway or process is chosen, reagents (e.g., epichlorohydrin and allyl halides) are all carcinogen agents (H350). Allyl bromide is also very toxic for the environment. The toxicity of these reactions is a true issue, and alternatives have to be found over time. Although the production of epoxides is 
generally well-controlled by the manufacturer and the resulting resins and materials do not exhibit the toxicity of these reactants, the intrinsic toxicity of BPA remains.

\section{Toxicity of Bisphenol A and Regulations}

Bisphenols (BPs) are part of the common class of endocrine disruptors because of their significant hormonal activity, with Bisphenol A being the most famous of them. In fact, BPA exhibits one of the highest production volume of chemicals worldwide [7], with a manufacture of approximately 3.8 million tons per year in 2006 [54]. About 80\% of the global production of BPA is used for the synthesis of polycarbonate, $18 \%$ for epoxy resins and the remainder for other applications, such as food containers, paper products (e.g., thermal receipts), water pipes, toys, medical equipment, and electronics [6,7]. As a consequence, human beings and environment are constantly exposed to BPA: it has been detected in $95 \%$ of human urine samples, which indicates that this compound may leach into food or water [7-9,55]. Furthermore, several studies found that BPA is present in high prevalence in fetuses and infants $[7,8,56]$ and has undeniably an impact on human health leading to precocious puberty, cancer, diabetes, obesity, neurological disorders, and so on. Theoretical and experimental studies can be carried out to forecast the potential toxicity of a compound or to determine the different types of interactions between this compound and estrogen receptors. For example, the "read-across" method, based on analogies between substances is currently developing. It first consists in gathering data on the physical and biological properties of chemicals exhibiting a structure similar to the target molecule. Then, by taking into account previously observed trends, it is considered possible to extrapolate on the target molecule's behavior [57]. QSAR (Quantitative Structure Activity Relationship) models enable a qualitative and quantitative determination of the endocrine activity in terms of affinity, and give some information about the underlying mechanism [58]. Recently, Delfosse et al. [59] described for the first time the mode of action of BPA at the molecular scale and developed a bio-informatics tool to predict the interactions between bisphenols and the target receptors (estrogen receptors (ERs) or other members of the nuclear hormone receptor family). Numerous studies demonstrated that bisphenol A has two major modes of actions: steroid related mode and epigenetic mode. Concerning the latter, Dolinoy et al. [60] have shown the ability of BPA to alter DNA methylation. Regarding the steroid related mode, BPA can act as an estrogen agonist when it binds to nuclear estrogen receptors $(E R \alpha$ and $E R \beta)$ [61-64]. More recently, Takayanagi et al. [65] demonstrated that BPA also binds to the estrogen-related receptor- $\gamma(\mathrm{ERR} \gamma)$ with high constitutive activity. Furthermore, BPA also behaves as an androgen receptor antagonist (AR) which affects the activation and function of the AR [66,67]. According to many lines of evidence, BPA acts as an endocrine disruptor even at low doses. A review, based on hundreds of studies, concluded that there is sufficient evidence for low dose effects of BPA. Indeed, for these studies, authors used doses below those used for traditional toxicological studies, and found nonmonotonic dose-response curves [68].

Bisphenols are composed of two phenols linked by a central carbon atom, which in the case of BPA bears two additional methyl groups (Figure 2B). These structural features make BPA able to mimic the natural estrogen $17 \beta$-estradiol (Figure 3), in terms of binding ability to estrogen receptors [69,70]. In fact, the main characteristics of the natural ligands required for the steroid activity are the presence of phenol groups on a hydrophobic backbone [71,72]. A recent paper has demonstrated that all the structural elements of BPA are prerequisite for binding the estrogen-related receptor- $\gamma(\mathrm{ERR} \gamma)$, especially the two phenolic and methyl groups [10]. Firstly, the authors demonstrated that the phenol structure of BPA is an essential element to bind ERR $\gamma$ and only one of the two phenolic hydroxy groups is required for the full binding. Nevertheless, the presence of a second oxygen-based group increases the steroid activity [73]. 
(A)
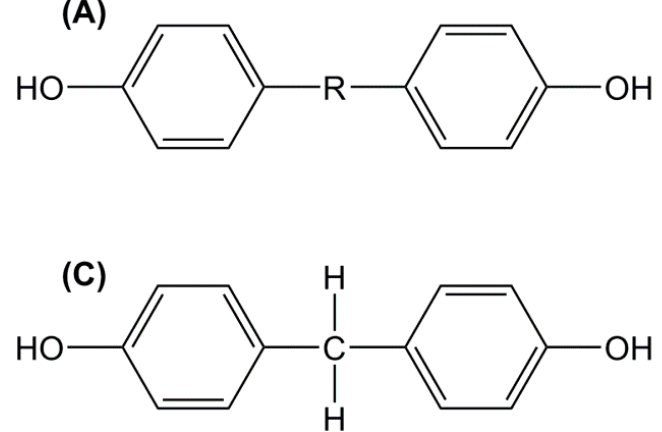
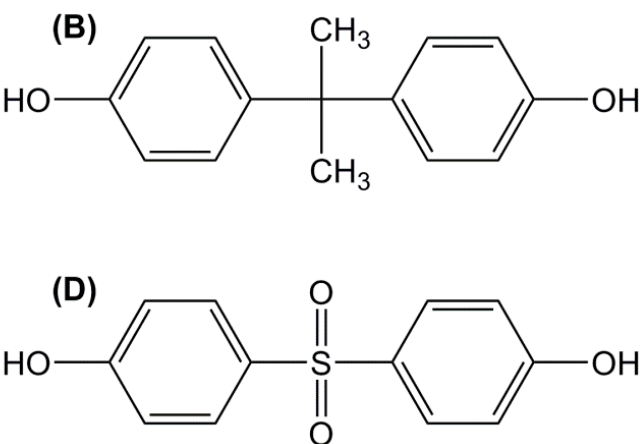

Figure 2. Chemical structures of bisphenol analogues (A); bisphenol A (B); bisphenol F (C) and bisphenol S (D).

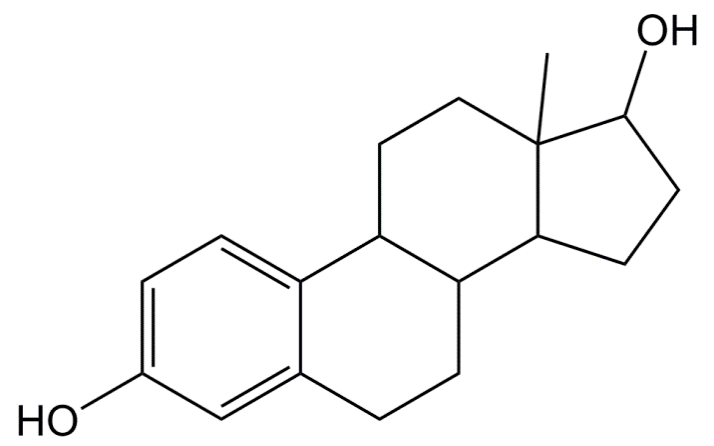

Figure 3. Structure of $17 \beta$-estradiol.

By analogy with $17 \beta$-estradiol, these two hydroxyl groups are essential to establish interactions with the hydrophobic pocket created by the receptor [74,75]. This pocket consists of several combining sites where estrogen or other ligands can bind. The size of the pocket is $440 \AA$ [74-76], which is bigger than the natural estrogen molecule size ( $245 \AA$ ) allowing hydrogen binding interactions (Figure 4$)$. Liu et al. [77] also showed that the substitution of one of the two aromatic rings by a methyl or ethyl group led to a decrease of the interaction with the hydrophobic part of the receptor, whereas the presence of chlorine substituents on the 3-5 positions of the first aromatic ring strengthens affinity with the receptor.

The presence and the distance between the two hydroxyl groups are not the only critical factors. Okada et al. [10] clearly demonstrated that the alkyl groups on the central carbon atom of bisphenol play a key role in selection of the human estrogen receptors: ERR $\gamma$ or ER $\alpha$. ER $\alpha$ prefers the bulkier and more electrophilic alkyl groups, whereas ERR $\gamma$ prefers the less bulky and less electrophilic alkyl groups. A bulky group on the central carbon atom is obviously disadvantageous in terms of binding BPA to ERR $\gamma^{\prime}$ s binding pocket and reduces its activity. Furthermore, it was shown that one of the two methyl groups on the central carbon atom of BPA is involved in the hydrophobic intermolecular interaction with the receptor residue, such as $\mathrm{CH}_{3}$-alkyl and $\mathrm{CH} / \pi$ interactions.

The increasing concerns about the detrimental effects of BPA has led governments to enforce regulations mostly in the European Union and North America in order to limit the exposition of their citizens to this substance. For example, in 2014, in line with the opinion adopted by the RAC (Risk Assessment Committee), Bisphenol A has been classified in the hazard class reproductive toxicity category 1B "may damage fertility". In the frame of the REACH regulation, the French proposition of the restriction of BPA in thermal papers was approved on the 6 July 2016 by the REACH Committee. The BPA European legislation involves different elements such as the restriction of the contact of infants and young people with this substance, through toys, feeding bottles, etc. [11,78-80]. BPA is authorized as additive or monomer in the manufacture of plastic materials and articles in contact with 
food and water but a specific migration limit value of $0.6 \mathrm{mg} / \mathrm{kg}$ of food has been set [12]. Regarding cosmetic products, Bisphenol A is recorded in the list of the prohibited substances [81]. All the products made of BPA can't be eligible for a positive Eco-Label [82] and the indicative limit of occupational exposure [83] to BPA particles is $10 \mathrm{mg} / \mathrm{m}^{3}$. Some countries such as France have established even more strict legislations towards BPA [84], and this country proposed BPA as a REACH Regulation candidate substance of very high concern (SVHC) [85] and confirmed its advert on the 30 August 2016.

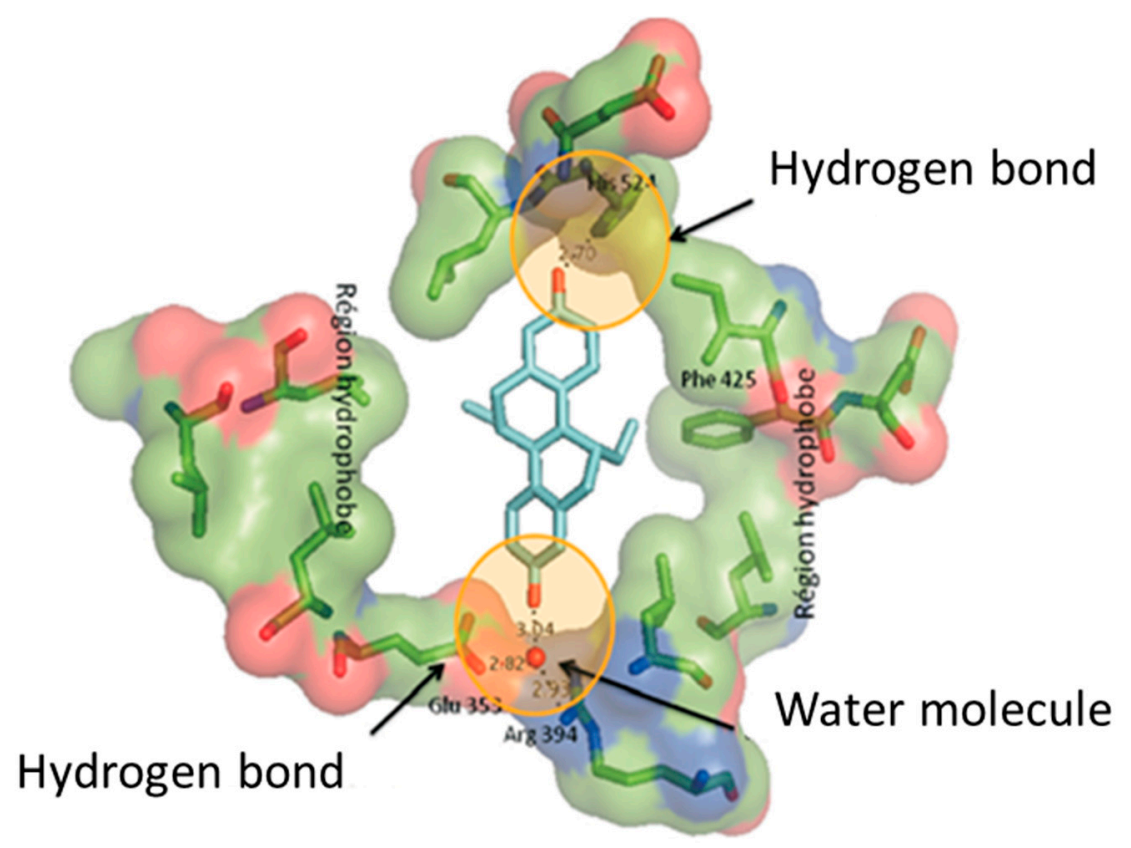

Figure 4. X-ray structure of the hydrophobic pocket of estrogen receptor (ER) $\alpha$ [76], according to the works of Brzozowski et al. [74] and Tanenbaum et al. [75].

Following the public concern and the stringent regulations on the production and use of BPA, several bisphenol analogues have been produced as alternative substances. These following analogues, BPF (4,4'-methylenediphenol) and BPS (4-hydroxyphenyl sulfone) (Figure 2C,D), are frequently found in most scientific and environmental studies because they are among the main substitutes of BPA in polycarbonate-based plastics and epoxy resins. Available studies have reported a variety of detrimental effects of these bisphenol analogues [86] and showed that the toxicity of these analogs is similar to or even greater than that of BPA $[87,88]$. The toxic effects include endocrine disruption, cytotoxicity, genotoxicity, reproductive toxicity, neurotoxicity, etc. A recent article by Rochester and Bolden [89], focusing on the hormonal activities of BPF and BPS demonstrated that these two analogues have a hormonal action similar to BPA in vitro and in vivo. Hexafluorobisphenol A (BPAF) and 4,4'-(1-methylpropylidene) bisphenol (BPB), two others substituents of BPA, have also shown estrogenic and anti-androgenic activities [88]. Therefore, a harmless let alone renewable epoxy building block is still required [90]. For this reason, bio-mass has been considered a cheap source of potentially functionalizable monomers or oligomers. As previously stated, the already commercialized bio-based epoxy monomers cannot compete with DGEBA-based materials in terms of thermo-mechanical properties, because of their characteristic structure and low aromatic content. Thus, the next part will briefly present the natural sources of renewable aromatic compounds potentially capable of standing up for BPA replacement.

\section{Main Natural Sources of Aromatic Moieties}

The present part will briefly summarize the main sources of aromatic moieties bearing reactive groups suitable for the introduction of epoxy moieties. This summary will include resources 
naturally containing small, phenolic compound such as eugenol extractible from plant natural oils, or polyphenolic crosslinked polymers such as tannins and lignin that can be directly functionalized or depolymerized into smaller molecules prior to epoxidation steps. Some information on their availability or worldwide production will be given as well as the main known characteristics of their structure. The reader may refer to the vastly documented review from Lochab et al. [91] and book from Belgacem and Gandini [92] on renewable resources and naturally occurring phenolic derivatives to obtain more detailed data.

\subsection{Lignin}

Lignin is the widest distributed aromatic biopolymer and the second most abundant naturally occurring macromolecule after cellulose, constituting from $1 \%$ to $43 \%$ by weight of the dry lignocellulosic biomass, with a potential availability exceeding 300 billion tons [17,93-95]. It is a cell-wall component bonding cells together in the woody stems, providing them with their well-known rigidity and impact resistance. Although its absolute structure remains unknown and varies according to the plant it originates from and its environment, lignin is an amorphous three-dimensional polymer network of three main methoxylated phenyl propane units (Figure 5) with seven major linkages: $\beta-O-4$ (aryl ether), $\alpha-O-4, \beta-\beta$ (pinoresinol), $\beta-5$ (phenylcoumaran), $\beta-1$ (diphenylmethane), 5,5 and 4-O-5 (diphenyl ether) linkages. It exhibits various functional groups such as aliphatic and phenolic hydroxyl, carboxylic, carbonyl and methoxy moieties.

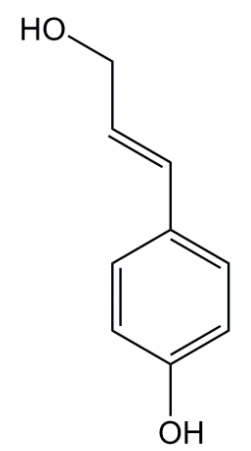

p-Coumaryl alcohol

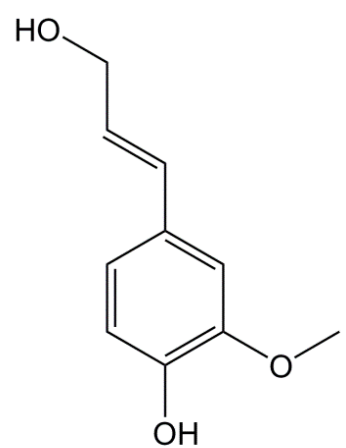

Coniferyl alcohol<smiles>COc1cc(/C=C/CO)cc(OC)c1O</smiles>

Sinapyl alcohol

Figure 5. Main aromatic subunits found in lignin.

Usually, lignin is viewed as a waste material derived from the wood pulp in the paper industry and available in large quantity (50-70 million of tons estimated) [96]. Unfortunately, only $1 \%$ to $2 \%$ of overall lignin is used for more specific applications, the remaining primarily serving as a (bio)fuel for the cellulose extraction [97]. Lignin is extracted from lignocellulosic biomass by two main categories of processes: (i) sulfur processes yielding lignosulfate and Kraft lignin and (ii) sulfur-free processes yielding organosolv and soda lignin. These extraction methods greatly influence the already complex structure of the polymer, sometimes making it difficult to directly use it as a chemical precursor. For this reason, works have been carried out to depolymerize lignin into smaller, simpler aromatic molecules suitable for chemical modification and/or polymerization. For example, when lignin is depolymerized, compounds such as vanillin, phenols derivatives, cresols, ferulic and coumaric acids are released (Figure 6). All these molecules are already oil-based but this pathway offers an interesting solution for their renewability, thus increasing thermosets renewability. 
<smiles>c1ccccc1</smiles><smiles>Cc1ccccc1</smiles><smiles>Cc1ccccc1</smiles><smiles>Oc1ccccc1</smiles><smiles>COc1ccccc1</smiles><smiles>Cc1ccccc1O</smiles><smiles>COc1ccccc1O</smiles><smiles>COc1cccc(OC)c1O</smiles><smiles>[R]CCCC1CCC(O)C(OC)C1</smiles><smiles>[R]CCCc1ccc(O)c(OC)c1</smiles><smiles>[R]C(=O)c1cc([R2])c(O)c([R])c1</smiles>

\begin{tabular}{|c|c|c|}
$\mathbf{R}_{1}$ & $\mathbf{R}_{2}$ & $\mathbf{R}_{3}$ \\
$\mathrm{H}$ & $\mathrm{H}$ & $\mathrm{H}$ \\
$\mathrm{H}$ & $\mathrm{OMe}$ & $\mathrm{H}$ \\
$\mathrm{H}$ & $\mathrm{OMe}$ & $\mathrm{OMe}$ \\
$\mathrm{OH}$ & $\mathrm{H}$ & $\mathrm{H}$ \\
$\mathrm{OH}$ & $\mathrm{OMe}$ & $\mathrm{H}$ \\
$\mathrm{OH}$ & $\mathrm{OMe}$ & $\mathrm{OMe}$ \\
$\mathrm{OH}$ & $\mathrm{OMe}$ & $\mathrm{CHO}$ \\
$\mathrm{OH}$ & $\mathrm{OMe}$ & $\mathrm{H}$ \\
$\mathrm{OH}$ & $\mathrm{OMe}$ & $\mathrm{COOH}$
\end{tabular}

Figure 6. Various aromatic moieties obtained from lignin depolymerization [93,94].

\subsection{Tannins}

Tannins are the second bio-based source of natural phenolic moieties and the third most abundant compounds extracted from wood biomass, with 160,000 tons bio-synthesized each year [98,99]. They can be found mainly in the soft tissues such as wood, bark, leaves or needles of all vascular and some non-vascular plants, in which they play a protective role against outside aggressions and in plant growth regulation [100]. Tannins are polyphenol derivatives with low molecular weights and can be divided into three main categories: hydrolysable tannins, condensed tannins and complex tannins, the latter being a combination of the first two.

Hydrolysable tannins are a mixture of phenolic esters of sugars (Figure 7A) readily hydrolyzed by acids, alkalis or enzymes, and present a low availability (less than $10 \%$ of the world's commercial production) [101]. They are mainly used in the tanning industry. The condensed tannins may represent the most interesting derivatives with $90 \%$ of global production. They are based on four types of repeating flavonoid units: profisetinidin, procyanidin, prorobinetidin, and prodelphinidin linked by $\mathrm{C} 4-\mathrm{C} 6$ or $\mathrm{C} 4-\mathrm{C} 8$ bonds (Figure 7B). Thanks to their availability, aromatic moieties and rigid structure, their numerous functionalizable hydroxyl functions and nucleophilic sites, condensed tannins may represent an interesting candidate for BPA substitution. Similarly to lignin, some studies are conducted on the depolymerization of tannins to obtain phenolic monomers as building units for thermosets $[98,102,103]$. For example, Roumeas et al. [102] successively used thiol and furan derivatives as nucleophiles for the acid-assisted depolymerization of condensed tannins into catechin and thioether or furan derivatives of catechin.

Finally, a last class of tannins, phlorotannins, can be found in non-vascular plants such as algae and are based on polymerized phloroglucinol (1,3,5-trihydroxybenzene) with a large range of molecular weights [98]. They play a role similar to condensed tannins in vascular plant and can as well be divided into categories according to the link between phloroglucinol units e.g., ether, phenyl bonds, a combination of both, or a dibenzo-p-dioxin bond (Figure 8). 
(A)<smiles>[R]CC(COC(=O)c1cc(O)c(O)c(O)c1)C1OC(=O)C(OC(=O)c2cc(O)c(O)c(O)c2)C(OC(=O)c2cc(O)c(O)c(O)c2)C1OC(=O)c1cc(O)c(O)c(O)c1</smiles><smiles>[R]O[R9](=O)O</smiles>

(B)

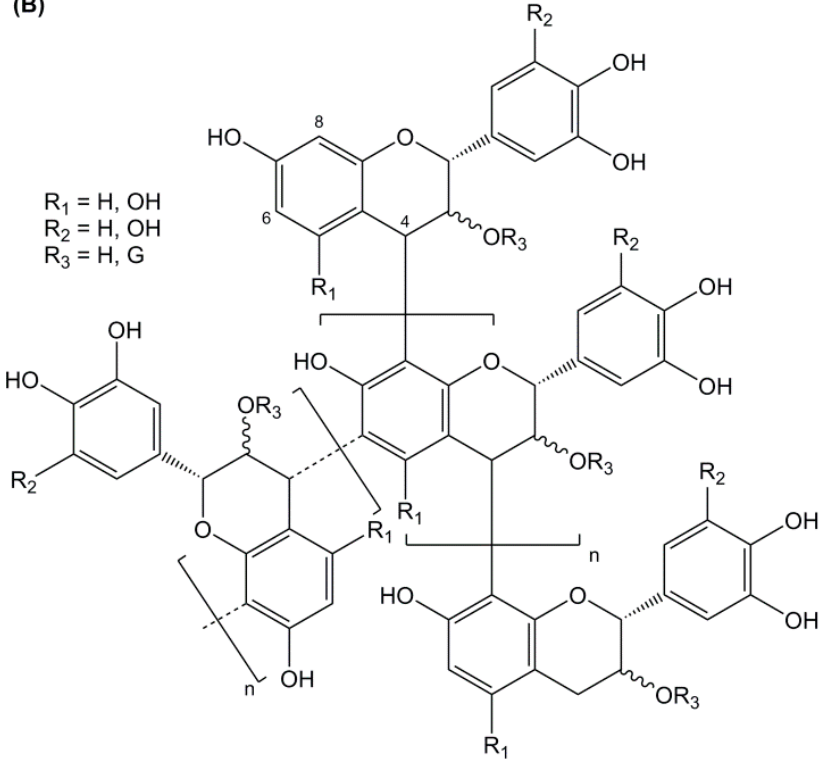

Figure 7. Main structures of tannins from vascular plants: hydrolysable tannins (A) and condensed tannins $(\mathbf{B})$.

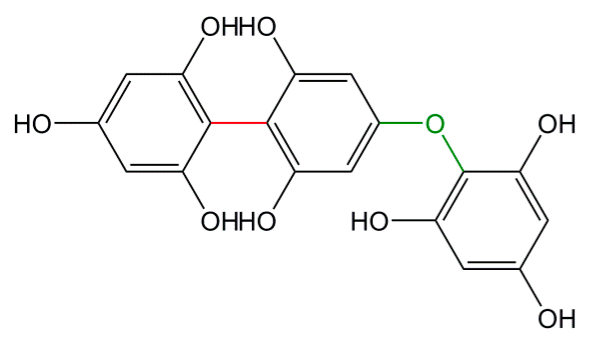<smiles>Oc1cc(O)c(Oc2cc3c(c(O)c2O)Oc2cc(O)c(Oc4cc(O)c(O)c(O)c4)c(O)c2O3)c(O)c1</smiles>

Figure 8. Example of phlorotannins linkages with phenyl bonds (in red), ether bonds (in green) and dibenzo- $p$-dioxin bond (in blue).

\subsection{Cardanol}

Cashew nut shell liquid (CNSL) is a reddish-brown liquid that can be extracted from the soft honeycomb structure located inside the cashew nut shell and constitutes from 30 to $35 \mathrm{wt} \%$ of it $[16,91,104]$. With approximately 2.1 millions of tons of cashew nuts produced every year, mainly from countries in Asia (India, Vietnam) and Africa (Nigeria, Ivory Coast), CNSL represents an abundant non-edible by-product that has already found various applications in coatings, laminates and adhesives to name a few. However, it also represents an interesting source of aromatic chemical building blocks. In fact, CNSL is mainly composed of four major phenolic derivatives: anacardic acid, cardanol, cardol and 2-methyl cardol (Figure 9), the percentage of which depends on the extraction method. Among these, cardanol is often regarded as the most interesting compound, as its percentage can reach $60 \%$ in some CNSL grades. Its structure is defined as a mono-aromatic phenol substituted in meta-position by a C15 alkyl chain, on which none to three unsaturations in C8, C11 and C14 are possible [105-107]. Thanks to its hydroxyl function and carbon-carbon double bond(s), cardanol can offer various functionalization opportunities, although its long aliphatic chain may severely impact materials in terms of thermo-mechanical properties. 

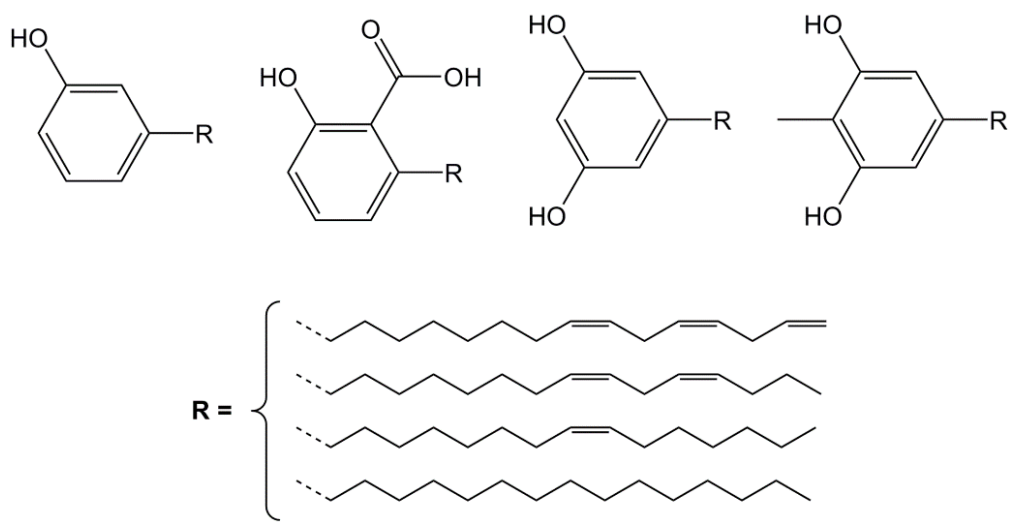

Figure 9. Main phenolic constituents of cashew nut shell liquid (from left to right): cardanol, anacardic acid, cardol and 2-methyl cardol [104].

\subsection{Cellulose and Hemi-Cellulose}

As previously stated, cellulose is the most abundant naturally occurring polymer and accounts for approximately $40-45 \mathrm{wt} \%$ of lignocellulosic biomass depending of wood species [108-111]. With an annual production estimated around 100 billion tons, it is a remarkable feedstock for the synthesis of renewable chemical building blocks. Cellulose is a crystalline high molecular weight polysaccharide (7000 to 15,000 monomeric units) formed of D-glucose linked by $\beta$-1,4-glycosidic bonds. The high chain organization through hydrogen bonding provides cellulose with interesting mechanical properties as well as poor solubility in water and various organic solvents. However, the several hydroxyl groups along its backbone make cellulose highly hydrophilic. Although it doesn't exhibit an aromatic structure, aromatic building blocks can be obtained from cellulose via depolymerization (Scheme 6) [112-114]. Through acid hydrolysis under harsh conditions or bacterial degradation [115] cellulose yields glucose that can further isomerize into fructose and then be dehydrated into 5-hydroxymethyl-2-furfural (HMF), a furanic aldehyde. HMF can also be oxidized into 2,5-furandicarboxylic acid or reduced into 2,5-furandimethanol, two symmetric di-functional aromatic moieties.

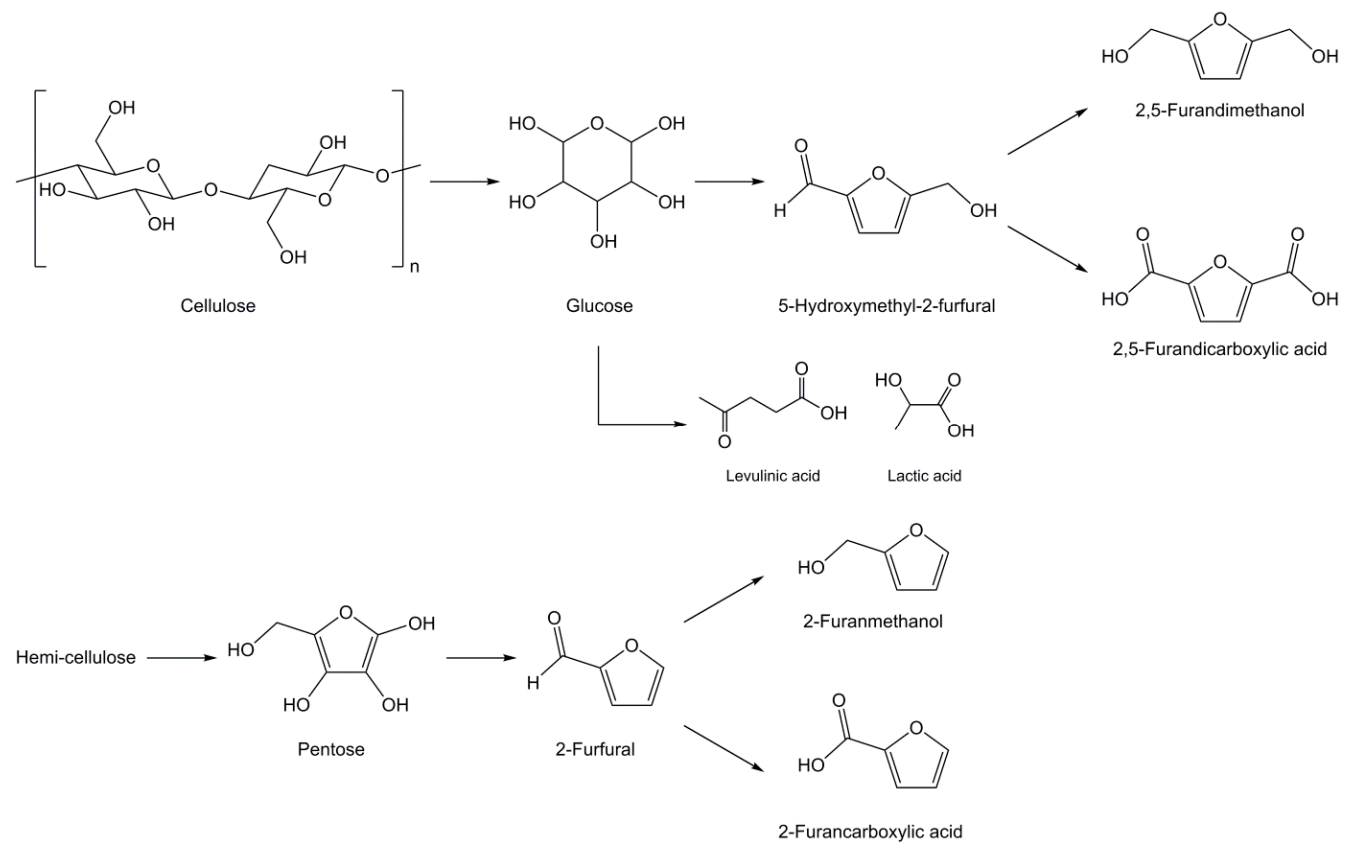

Scheme 6. Synthesis of furan derivatives from cellulose and hemi-cellulose [112-114]. 
The other main component of lignocellulosic biomass, namely hemi-cellulose, is an amorphous polysaccharide with short chains of 500 to 3000 monomer units with acidic groups. Similarly to cellulose, it can be depolymerized into pentose that can further be transformed into 2-furfural, 2 -furanmethanol and 2-furancarboxylic acid. However, these derivatives are mono-functional, thus making them unsuitable for the synthesis of di-epoxy monomers, only fit for reactive diluents. Finally, it is also worth noting that cellulose can also be degraded into other interesting, although non aromatic, building blocks: levulinic and lactic acid.

\subsection{Other Natural Sources of Aromatic Moieties}

Some other abundant biomasses are potential candidate to extract or synthesize phenolic derivatives. For example, terpenes and terpenoids can be obtained from various plants' essential oils or as by-products of industrial processes and are largely available at reasonable prices [116-118]. For example, 700 millions of $\mathrm{kg}$ of limonene are produced annually as a side-product of orange juice production [117]. Terpenes form a large and diverse class of molecules based on repeating isoprene units that can be linked head to tail or form cycloaliphatic or aromatic rings such as in $\alpha$-pinene found in pines, limonene from citrus fruits or $p$-cymene extracted from thyme, only to name a few. Some of them may represent interesting candidates for the synthesis of epoxy monomers such as carvacrol, which exhibits a phenol moiety and a carbon-carbon double bond (Scheme 7) and can be isolated from oregano and thyme essential oils. However, not all terpenoids contain aromatic and/or phenolic moieties, but these requirements can be reached via different synthesis steps. For example, carvacrol can be obtained from other turpentine components such as limonene via an oxidation followed by an isomerization with sulfated zirconia or from $p$-cymene by the action of concentrated sulfuric acid and sodium hydroxide [117].

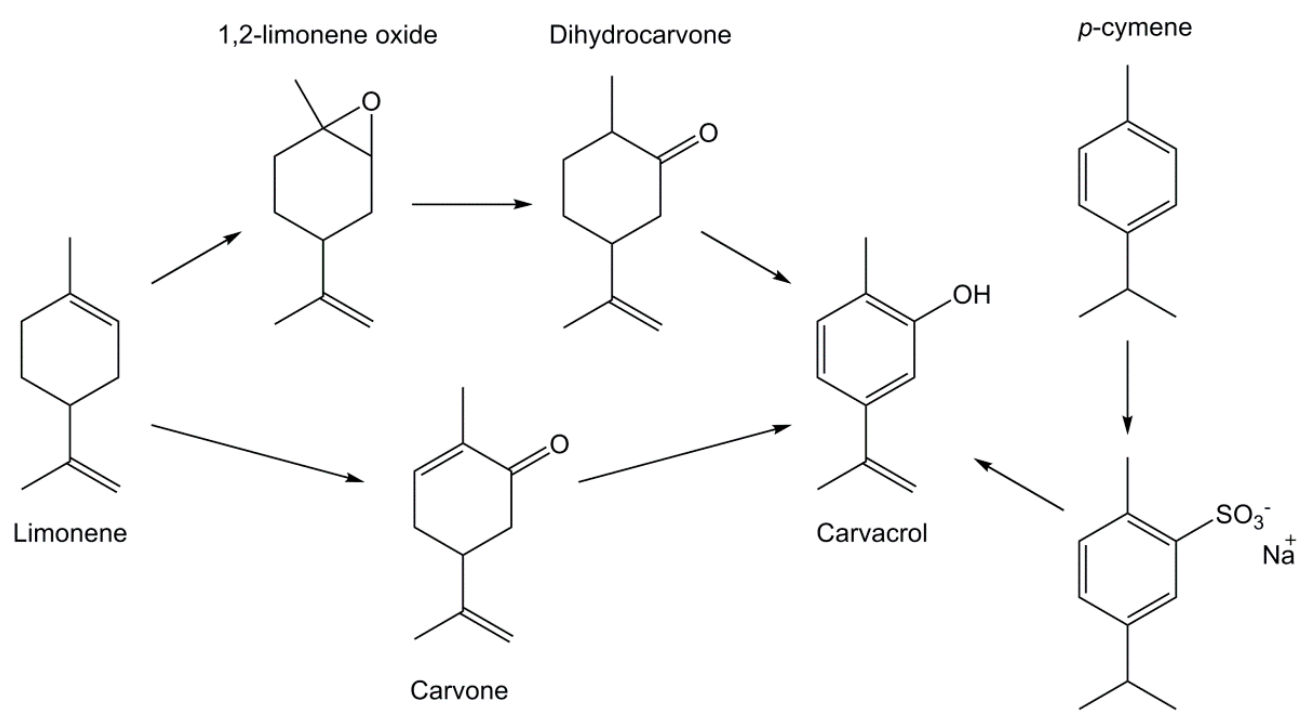

Scheme 7. Synthesis of carvacrol from limonene or $p$-cymene according to Harvey et al. [117].

Other phenolic compounds can be extracted from various plant essential oils such as 4-allyl-2-methoxyphenol, commonly known as eugenol (Figure 10), obtained from clove oil where it accounts for $80 \%$ [119-122], Jamaican chili, cinnamon and bay leaves from California. It is a renewable resource, but it is also considered safe, non-carcinogenic and non-mutagenic by the U.S. Food and Drug Administration and used as a food flavoring agent. Furthermore, it exhibits several pharmacological properties such as anesthetic, antioxidant, and antimicrobial activities. Apart from extraction, eugenol can be synthesized by allylation of guaiacol, another bio-based phenolic derivative. The main advantage of eugenol is that it exhibits a carbon-carbon double bond with fair reactivity and a phenolic group, thus allowing various functionalizations. 
<smiles>C=CCc1ccc(O)c(OC)c1</smiles>

Eugenol<smiles>COc1cc(/C=C/C(=O)O)ccc1O</smiles>

Ferulic Acid

Figure 10. Structures of eugenol and ferulic acid.

Lignocellulosic biomass may also contain $p$-coumaryl, coniferyl and sinapyl acids, depending on the plant species, that act as crosslinkers between lignin and polysaccharides (cellulose and hemi-cellulose) to increase the rigidity of the materials. Among these, 3-methoxy-4-hydroxycinnamic acid (Figure 10), also known as ferulic acid, is an abundant derivative that can be extracted in good yields from various non-food resources such as bagasse, rice, wheat and sugar beet roots [123-126] and has both a hydroxyl group and an aliphatic carboxylic acid, thus enabling functionalization. It also exhibits antioxidative, anti-tumor, photoprotective and anti-hypertensive activities.

\section{Bio-Based Aromatic Epoxy Compounds}

\subsection{Mono-Aromatic Epoxy Compounds}

Mono-aromatic glycidyl compounds are defined by having strictly one aromatic ring per molecule and by having two or more epoxy groups per molecule. As previously stated, the characteristic structure of BPA, e.g., its length, its two aromatic rings and alcohols functions greatly influence its endocrine disruptor activity. Thus, mono-aromatic molecules with reduced hydrophobic skeleton may potentially be less likely to bind with estrogen receptor, making their epoxy monomers interesting candidates for BPA substitution, however, specific studies would be necessary before these compounds can be proposed as BPA substitutes.

\subsubsection{Phenyl-Based Di-Functional Epoxy Monomers}

Various mono-aromatic phenyl-based epoxy monomers have been considered as potential candidates for the replacement of DGEBA (Figure 11). One of the simplest, diglycidyl ether of resorcinol (1), is obtained from resorcinol, a meta-substituted di-phenol that can be obtained from biomass by fermentation [127] of catechins or by fermentation of glucose into inositol, chemical conversion of the latter into 1,3,5-benzenetriol (or phloroglucinol) and finally reduction. As a part of catechin's skeleton structure, it has been used as model molecule for catechin characterization [128]. It is commercially available or can be prepared by direct $O$-glycidylation of resorcinol with good yield (87\%) [38]. Because of the resonance and inductive effects of the meta-substituted aromatic ring, diglycidyl ether of resorcinol should be more reactive than its para-substituted analogue, diglycidyl ether of hydroquinone (3) [129]. Its high toxicity may explain why this epoxy has not been much used as material component. Similarly, a substituted resorcinol, methyl-2,4-dihydroxybenzoate has been glycidylated with epibromohydrin (2) with a 78\% yield but no materials have been developed from this compound [24]. On the contrary, diglycidyl ether of hydroquinone, the para isomer or resorcinol can be obtained via the microbial synthesis of phloroglucinol or quinic acid from glucose, converted into hydroquinone (or resorcinol) [130]. This epoxy was cured with diethyl toluene diamine (EPIKURE W) and the obtained materials exhibited slightly higher glass transition temperature $\left(T_{\mathrm{g}}\right)$ than those based on DGEBA (up to $8^{\circ} \mathrm{C}$ ) [131], being the greatest data obtained with a di-functional epoxy. However, contrary to resorcinol, hydroquinone is carcinogen (H351) and mutagen (H341). 


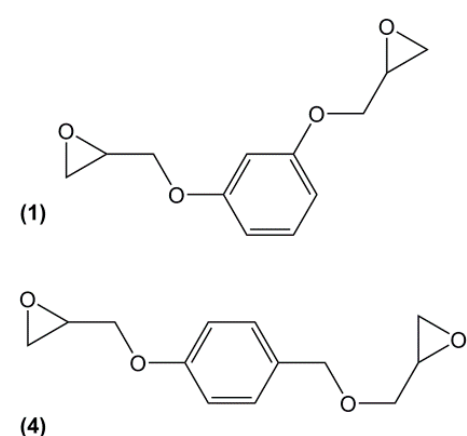

(2)

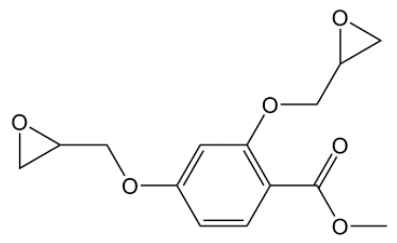

(5)

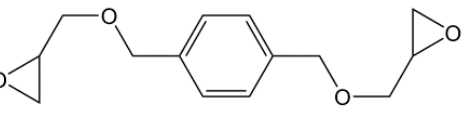

(7)

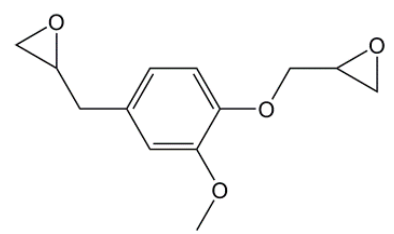

(3)
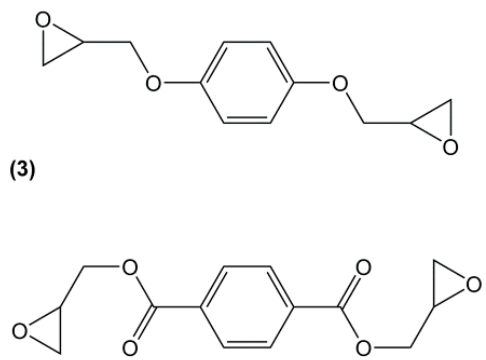

(6)

Figure 11. Mono-aromatic phenyl-based di-functional epoxy compounds.

The same research team prepared the diglycidyl ether of $p$-xylene alcohol (5) by direct glycidylation of the non-toxic 1,4-benzenedimethanol with an overall yield of $90 \%$ and a purity of $99 \%$ assessed by ${ }^{1} \mathrm{H}$ NMR [131]. It has been cured with cycloaliphatic and aromatic diamines, 4, $4^{\prime}$-methylene biscyclohexylamine (PACM) and diethyl toluene diamine (EPIKURE W), respectively yielding materials with $T_{\mathrm{g}}$ values up to $67^{\circ} \mathrm{C}$ lower than those of DGEBA-based equivalents, because of the methylene linkages.

The ester form of the latter compound was prepared by direct glycidylation of the non-toxic terephthalic acid [132], to form diglycidyl ester of terephthalic acid (6) with a yield of $80 \%$. This epoxy was cured with methylhexahydrophthalic anhydride and poly(propylene glycol) bis(2-aminopropyl ether). The materials showed similar $T_{\mathrm{g}}$ values as those based on DGEBA with both curing agents. Furthermore, terephthalic acid is synthesized from $p$-xylene that can be obtained from bio-mass by various processes [133]. Due to the large amount of by-products using both direct glycidylation and allylation methods, You et al. [134] prepared diglycidyl ester of terephthalic acid by esterification of diacyl chloride by glycidol, with a 50\% yield. Diglycidyl ester of terephthalic acid was cured with carboxylic acid derivatives, and the corresponding materials were used as biocompatible, biodegradable and functional polymers for biomedical applications. No thermal properties were reported. However, the low hydrolytic stability of aromatic ester groups is expected to negatively impact the potential materials [134].

The double functionalization of eugenol (7) requires a three-step route: (i) protection of the hydroxy group via an acetylation using acetic anhydride; (ii) oxidation of the double bond using $m C P B A$ and (iii) glycidylation by deacetylation using epichlorohydrin. The resulting solid was obtained with an overall yield of 53\% [119]. The epoxy was cured with anhydrides and the obtained materials showed similar thermal and mechanical properties than those of DGEBA equivalents. For example, when diglycidyl ether of eugenol was cured with hexahydrophtalic anhydride, the obtained $T_{\mathrm{g}}$ reached $114^{\circ} \mathrm{C}$, which was slightly higher than that of DGEBA counterparts $\left(106^{\circ} \mathrm{C}\right)$.

Eugenol can be used as a precursor for vanillin synthesis. The latter is an important bio-based phenolic aldehyde, which is the main component of vanilla bean extract, widely used as flavouring in food, beverages and pharmaceuticals [135]. It is also a bio-sourced chemical derived from lignin currently produced by Borregaard [123] that easily allows to lead to diepoxy compounds, the structures of which are showed in Figure 12. All diglycidyl ethers deriving from vanillin can be prepared by direct $O$-glycidylation of the corresponding alcohol derivatives, with good yield $(85 \%-89 \%)$ [27]. It is interesting to note that the alcohol derivatives, e.g., 4-hydroxy-3-methoxybenzyl alcohol, 2-methoxyhydroquinone and 4-hydroxy-3-methoxybenzoic acid are all commercially available, 
non-toxic and also used for food flavouring. The three diglycidyl ether compounds were cured with isophorone diamine (IPDA) and showed $T_{\mathrm{g}}$ values lower than that of DGEBA by 69 (9), 34 (8) and $14{ }^{\circ} \mathrm{C}(\mathbf{1 0})$. The authors considered that the presence of a methylene spacer decreased $T_{\mathrm{g}}$ by $35^{\circ} \mathrm{C}$ and when carbonyl group was used as spacer, $T_{\mathrm{g}}$ increased by $20^{\circ} \mathrm{C}$. Additionally, when diglycidyl ether of hydroquinone and diglycidyl ether of methoxyhydroquinone were compared, the presence of the methoxy group involved a decrease of $T_{\mathrm{g}}$ by $25^{\circ} \mathrm{C}$. Similarly, when comparing (8) and diglycidyl ether of eugenol (7), it seems that the loss of the $\left(\mathrm{CH}_{2}-\mathrm{O}-\right)$ group between the oxirane ring and the aromatic ring allows to reach higher glass transition temperatures, closer to those of DGEBA-based materials.

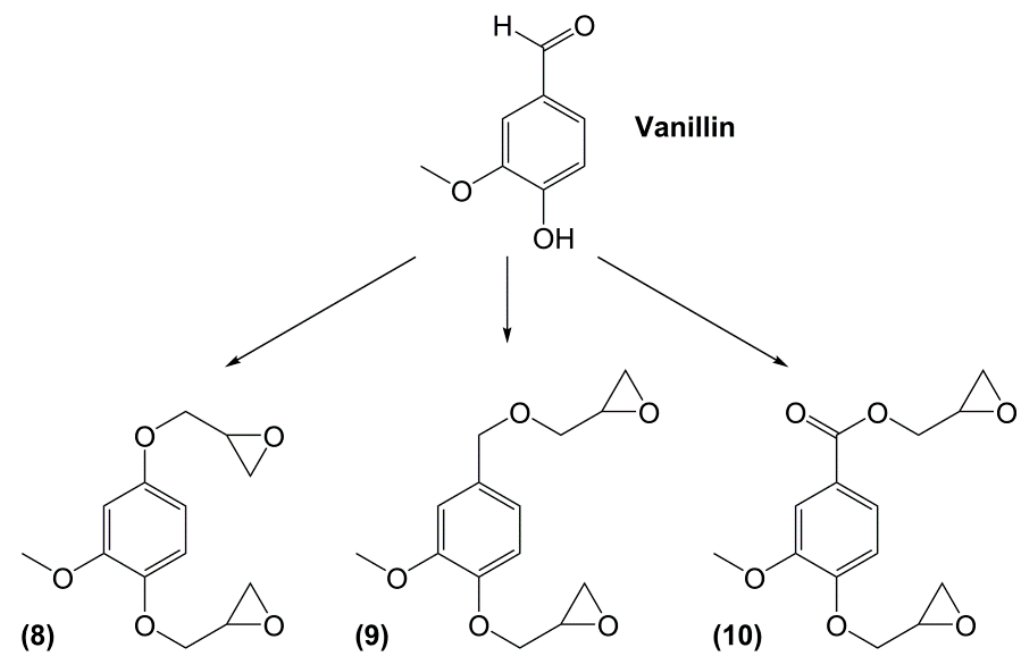

Figure 12. Diglycidyl ether compounds obtained from vanillin: (8) diglycidyl ether of vanillyl alcohol, (9) diglycidyl ether of methoxyhydroquinone and (10) diglycidyl ether of vanillic acid [135].

Recently, Hernandez et al. [17] continued the researches to determine the influence of the methoxy group of diglycidyl ether of vanillyl alcohol (DGEVA) (9) by comparing it with diglycidyl ether of gastrodigenin (DGEGD) (4). When cured with 4,4'-methylbiscyclohexylamine, the DGEVA-based materials exhibited a lower $T_{\mathrm{g}}$ than the DGEGD ones due to the methoxy moiety, but it appears that it enables to obtain a higher rigidity in the glassy state, as observed via the higher storage modulus.

Following its previous work on lignin depolymerisation using hydrogenation in the presence of $\mathrm{Zn} / \mathrm{Pd}$ catalysts $[136,137]$ the team of Abu-Omar [138] synthesized di-epoxides from propylcatechol (11) (Scheme 8). As previously explained, the presence of hydroxyl groups in ortho position will yield benzodioxane derivatives during the glycidylation step, but the authors claimed to have improved the synthesis conditions in terms of epoxy equivalent weight and mass ratio. The epoxy monomer was then mixed with octadecylamine-modified nano-montmorillonite and cured with diethyl triamine. The bio-based polymers were characterized in terms of thermal stability and mechanical properties but no possible leaching of the benzodioxane derivatives non-integrated in the network was discussed.

Another abundant and natural product is rosin. With a production of approximately 1.2 million of tons per year [19], this compound is obtained by heating fresh tree resin to remove the volatile liquid terpenes. It thus contains a mixture of isomerized acid with large hydrogenated phenanthrene ring structures providing them with high rigidity. Most of them do not contain aromatic structures, but Liu et Zhang [139] recently synthesized a mono-aromatic di-glycidyl ester based on rosin acid (12) (Figure 13), cured it with 1,2-cyclohexanedicarboxylic anhydride and compared the results with DER332, an epoxy resin from Dow Chemical Company cured in the same conditions. The resulting material exhibited a $T_{\mathrm{g}}$ of $154^{\circ} \mathrm{C}$ slightly higher than its counterpart, and a good thermal stability with a temperature of $5 \%$ weight loss of $311^{\circ} \mathrm{C}$. 


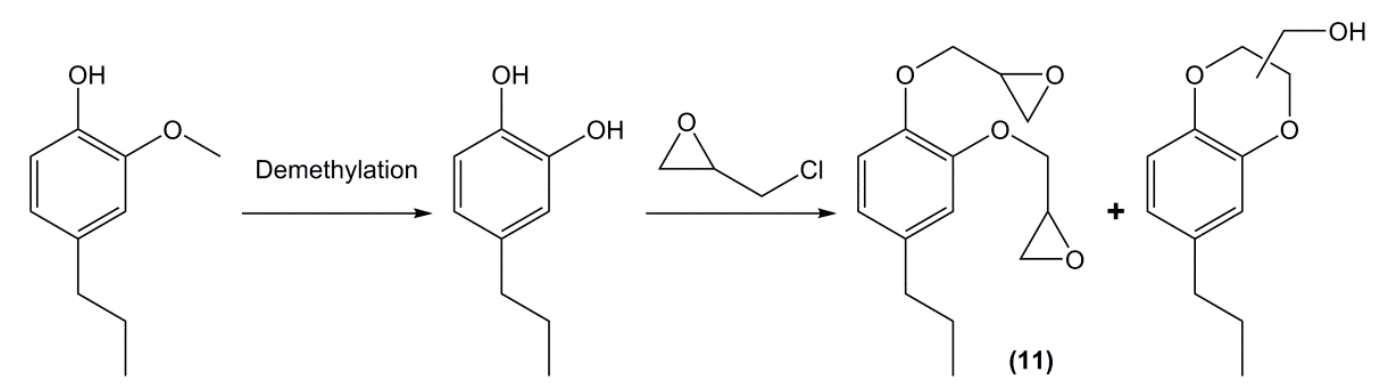

Scheme 8. Synthetic pathway to glycidylated propylcatechol as described by Zhao and Abu-Omar [138].

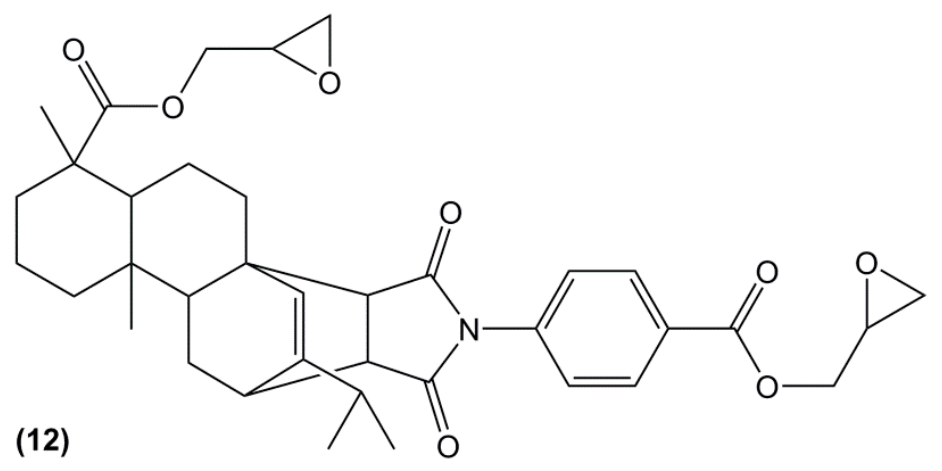

Figure 13. Chemical structure of a rosin-based diepoxy compound [139].

\subsubsection{Phenyl-Based Poly-Functional Epoxy Monomers}

Phloroglucinol is a bio-based tri-phenol and is used as an active ingredient in medicines (SPASFON). The glycidylated compound (13) (Figure 14) was prepared by direct glycidylation with a yield of $68 \%$, leading to a mixture mainly containing triglycidyl ether of phloroglucinol [140]. Its symmetric tridimensional and tri-functional meta-substituted structure makes it the most reactive epoxy [129]. The reached materials exhibited much higher $T_{\mathrm{g}}$ than those of DGEBA, up to $60^{\circ} \mathrm{C}$ for linear aliphatic [141] and $20^{\circ} \mathrm{C}$ for cycloaliphatic diamines [142].

Another simple tri-functional glycidyl ether is based on pyrogallol (14), which is also a bio-based molecule obtained from decarboxylation of gallic acid extracted from hydrolysable tannins. Unfortunately, it is mutagen (H341) and its structure produces more bulkiness than its meta-substituted analogue. Moreover, as previously described, the ortho position of the phenol groups yields a 50:50 mixture of triglycidyl ether of pyrogallol and benzodioxane derivatives, with an overall yield of $66 \%$ [38]. The low yield and by-products synthesis were likely the reason why no material has been prepared from this epoxy.

Similarly, protocatechuic acid, which is a relatively toxic (H315, H319, H335) major metabolite of antioxidant and anti-inflammatory bio-based polyol found in green tea, yields a mixture of $60 \%$ of the triglycidyl ether (15) and $9 \%$ of the benzodioxane derivative [38]. The presence of the carboxyl group in meta-position apparently limited the cyclization compared to pyrogallol. Despite the good yield, no material has been reported.

Another triglycidylated compound was synthesized from trimellitic acid (16), which is a relatively toxic triacid. The epoxy form was found at $25 \%$ in a mixture with $75 \%$ of diglycidyl terephthalate acid ester, supplied by Vantico-Switzerland. This mixture was used as polyester curing agent for coating applications. No thermal properties of the intrinsic materials have been reported [143,144], but a low hydrolytic stability is expected similarly to the diglycidyl ester of terephthalic acid (6). 
<smiles>c1c(OCC2CO2)cc(OCC2CO2)cc1OCC1CO1</smiles><smiles>O=C(OCC1CO1)c1ccc(OCC2CO2)c(OCC2CO2)c1</smiles><smiles>O=C(OCC1CO1)c1ccc(C(=O)OCC2CO2)c(C(=O)OCC2CO2)c1</smiles><smiles>c1cc(OCC2CO2)c(OCC2CO2)c(OCC2CO2)c1</smiles>

(17)<smiles>O=C(OCC1CO1)c1cc(OCC2CO2)c(OCC2CO2)c(OCC2CO2)c1</smiles>

Figure 14. Mono-aromatic phenyl-based poly-functional epoxy compounds.

Gallic acid is a bio-based, trihydroxybenzoic acid compound encountered in the plant hydrolysable tannins, as gallic acid derivatives (esters, glycosides) or as the acyl group of some polyols (glucose, quinic acid). It is as toxic as protocatechuic acid and is the only mono-aromatic compound with four functions that can be glycidylated. Tetraglycidyl ether of gallic acid (17) can be prepared by direct glycidylation or allylation $[22,145]$. The direct glycidylation of gallic acid allowed to reach the targeted product with a yield of $68 \%$ [22,146,147], whereas, the allylation route led to a better control of the functionalization, but a lower overall yield of tetraglycidyl derivative of $48 \%$. The materials cured using isophorone diamine reached $T_{\mathrm{g}}$ values of $73{ }^{\circ} \mathrm{C}$ higher than that of DGEBA, which is the highest value obtained for mono-aromatic epoxy compounds [22].

Cardanol has also been considered as a BPA substitute for epoxy monomer synthesis. The conversion of the $\mathrm{C}=\mathrm{C}$ double bonds to epoxide groups can be almost complete by reaction with hydrogen peroxide in the presence of formic acid and $p$-toluenesulfonic acid, with a yield of $82 \%$. The resulting product is only glycidylated along the alkyl chain and is used for its antioxidative activity in soybean oil [106].

Fully epoxidized cardanol (18) (Figure 15) was prepared by direct O-glycidylation of the phenol, followed by double bonds oxidation using $m$ CPBA (78\%) or perbenzoic acid and used as a natural plasticizer for PVC films [105] or as diluent to improve the mechanical properties of DGEBA cured by phthalic anhydride for glass-fiber reinforcement applications. For this latter application, $T_{\mathrm{g}}$ increased with the amount of epoxidized cardanol, from 145 to $180^{\circ} \mathrm{C}$ using $40 \%$ of diepoxy cardanol [107]. No epoxy/amine-based material has been reported, likely because the epoxy groups along the alkyl chain exhibit a lower reactivity toward amines. In fact, glycidyl ether compounds are found to be the most reactive species towards amine compounds because of the inductive effect of the oxygen on the epoxy-ring and the fact that the ether oxygen is able to form hydrogen bonds with the amine [129]. An interesting approach is thus to combine both characteristics in one molecule. 

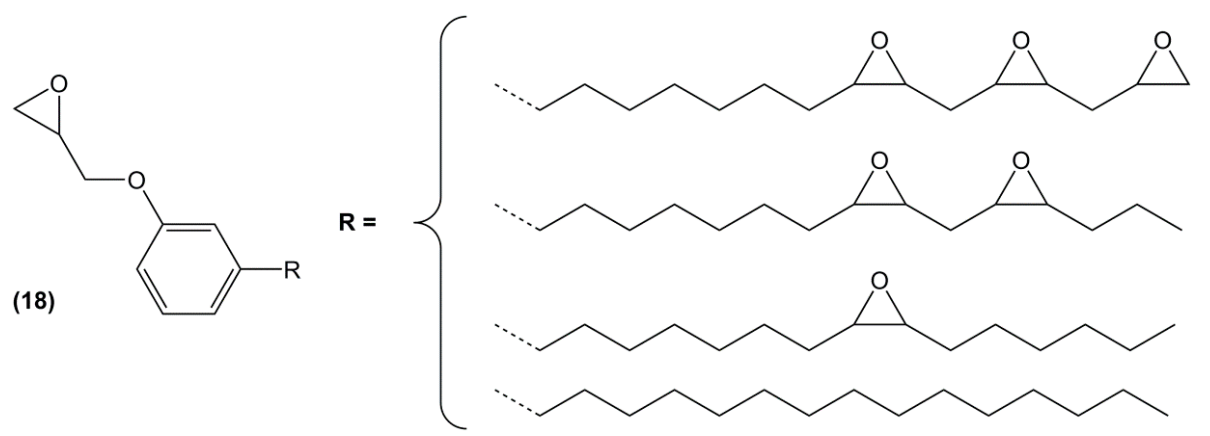

Figure 15. Theoretical structure of epoxidized cardanol.

Triglycidyl ether of vanillylamine (19) (Figure 16) is the only tri-functional mono-phenolic glycidylated derivative synthesized from the bio-based and non-toxic vanillin reported in the literature [148]. It was prepared in a four-step synthesis from hydroxylamine hydrochloride: (i) aldoximation of vanillin; (ii) reduction of the aldoxime using dihydrogen in the presence of $\mathrm{Pd} / \mathrm{C}$; (iii) neutralization in basic medium leading to a potential alkanolamine hardener; (iv) direct $\mathrm{N}$-glycidylation of the resulting vanillylamine, with an overall yield of $61 \%$. The materials cured with isophorone diamine showed similar $T_{\mathrm{g}}$ than that of triglycidyl ether of phloroglucinol.

(19)

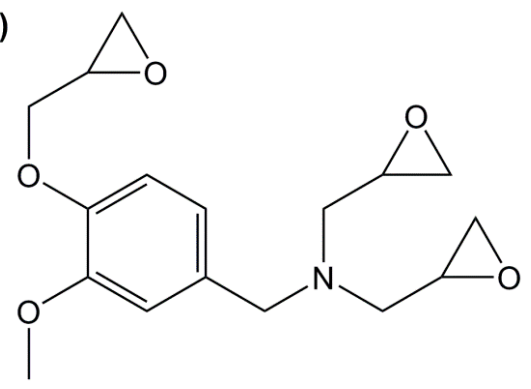

Figure 16. Aromatic derivatives with epoxy groups grafted on nitrogen atoms.

\subsubsection{Epoxy Monomers Based on Other Aromatic Rings}

Furfuryl diglycidyl ether (20) (Figure 17) was prepared by direct glycidylation of the 5-hydroxymethyl-2-furfural, with a yield of $60 \%$ and a purity of $99 \%$-however 5-hydroxymethyl-2 -furfural is a toxic substance. Hu et al. [149] found that the overall reactivity of furan derivatives was significantly greater than that of the phenyl analogue and led to materials with a glass transition temperature higher than their benzene analogs. However, in a recently corrected article [150], the research group changed their observations and conclusions as the benzyl-based materials showed higher $T_{\mathrm{g}}$ values than the furan-based ones, due to a higher freedom degree of the furan ring and the hydrogen bonding between atoms in the furan rings and hydroxyl groups created by the epoxy opening.

In another article, their further investigation on furfuryl diglycidyl ether cured with difurfurylamine led them to conclude that each methylene spacer per ring reduced the $T_{\mathrm{g}}$ by $32-34{ }^{\circ} \mathrm{C}$ and that furanyl structure led to higher freedom degree, which decreased $T_{\mathrm{g}}$ [151]. When compared with those obtained from DGEBA, the mono-aromatic furan-based materials showed a $T_{\mathrm{g}}$ in between 66 and $97^{\circ} \mathrm{C}$ lower.

Furfuryl diglycidyl ester (21) was prepared by allylation and epoxidation of the bio-based but irritant 2,5-furandicarboxylic acid, in an overall yield of 59\% [132]. The authors reported that the furandicarboxylic-based materials displayed higher curing reactivity, higher $T_{\mathrm{g}}$, similar mechanical properties and thermal stability than those based on terephtalic derivatives. The freedom degree of 
furandicarboxylic structure is lower than with a methylene spacer, which is consistent with previous observations [135,151], but lower stability toward hydrolysis is expected.<smiles>c1coc(COCC2CO2)c1</smiles>

\section{(22)}<smiles>O=C(OCC1CO1)c1ccc(C(=O)OCC2CO2)o1</smiles><smiles>c1coc(CN(CC2CO2)CC2CO2)c1</smiles>

Figure 17. Furan-based diglycidylated compounds.

$N, N^{\prime}$-Diglycidyl furfurylamine (22) was synthesized by double $N$-glycidylation of the relatively toxic 2-aminomethylfurfuran, with an overall yield of 50\% [152]. When the resulting multi-functional epoxy was cured with maleimide and anhydride species, stable thermally reversible linkages were formed, leading to self-healing thermosetting materials.

Recently Liu et al. [153] developed a six-armed epoxy resin (23) based on linoleic acid and hexamethylol melamine in a two-step process of esterification and epoxidation with $\mathrm{H}_{2} \mathrm{O}_{2}$ (Figure 18). Their goal was to reduce the high flexibility induced by the long aliphatic chain of the vegetable oils by introducing a rigid aromatic group. Resins were cured using 4-methyl hexahydrophthalic anhydride and 1,8-diazabicyclo[5.4.0]undec-7-ene as a catalyst and exhibited high degrees of cure, $T_{\mathrm{g}}$ values between 28 and $42{ }^{\circ} \mathrm{C}$ higher than those observed when epoxidized sucrose soyate was used. However, their temperature at $5 \%$ weight loss turned out to be from $20-90{ }^{\circ} \mathrm{C}$ lower, thus indicating a poorer thermo-oxidative stability. With similar hardener content, the resin presented a bio-based content of $70 \%$ vs. $80 \%$ for the sucrose soyate-based one.

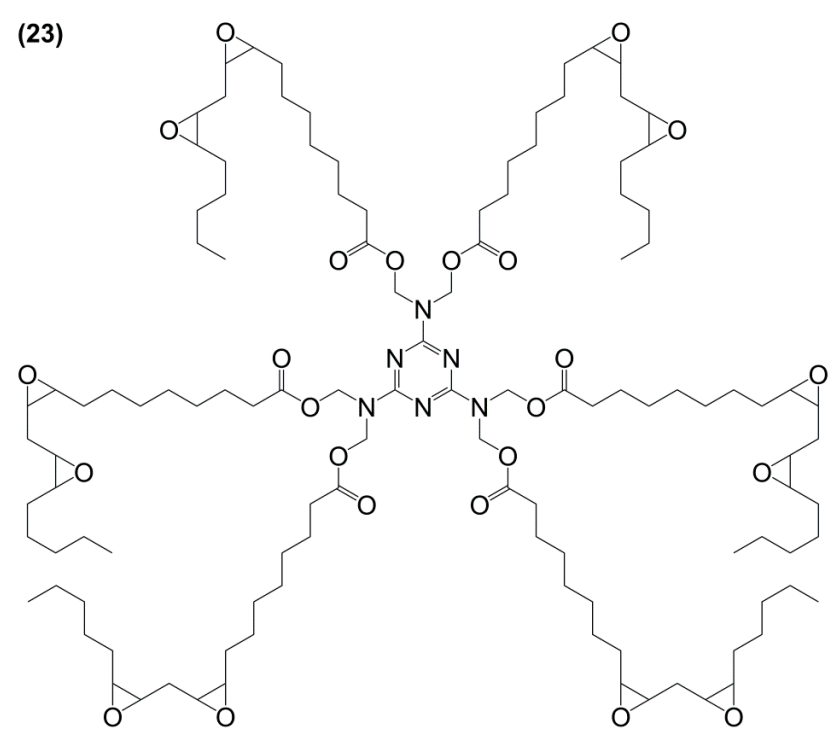

Figure 18. Structure of the glycidylated hexa(linoleoyl hydroxymethyl) melamine [153].

\subsubsection{Conclusions}

Bio-based mono-aromatic epoxy materials show interesting properties in terms of $T_{\mathrm{g}}$ and thermal stability. While cardanol-based materials exhibit flexibility and low $T_{\mathrm{g}}$ values, tri- and tetraglycidyl 
ether, led to materials with higher $T_{\mathrm{g}}$ than DGEBA-based materials. Among the di-functional mono-aromatic substances, only the materials based on epoxy with no spacer and separated by a carbonyl group showed higher $T_{\mathrm{g}}$. Unfortunately, since most of these epoxides are in development, their toxicity is not known and at that moment, little information is available on the potential endocrine disruption of their precursors. Tables 1 and 2 gather the known data on materials based-on mono-aromatic di- and poly-epoxy monomers from renewable resources.

Table 1. Mono-aromatic, di-epoxy monomers and thermal properties of the cured materials. $T_{\mathrm{g}}$ values are indicated in plain text, $T_{\alpha}$ are in italics.

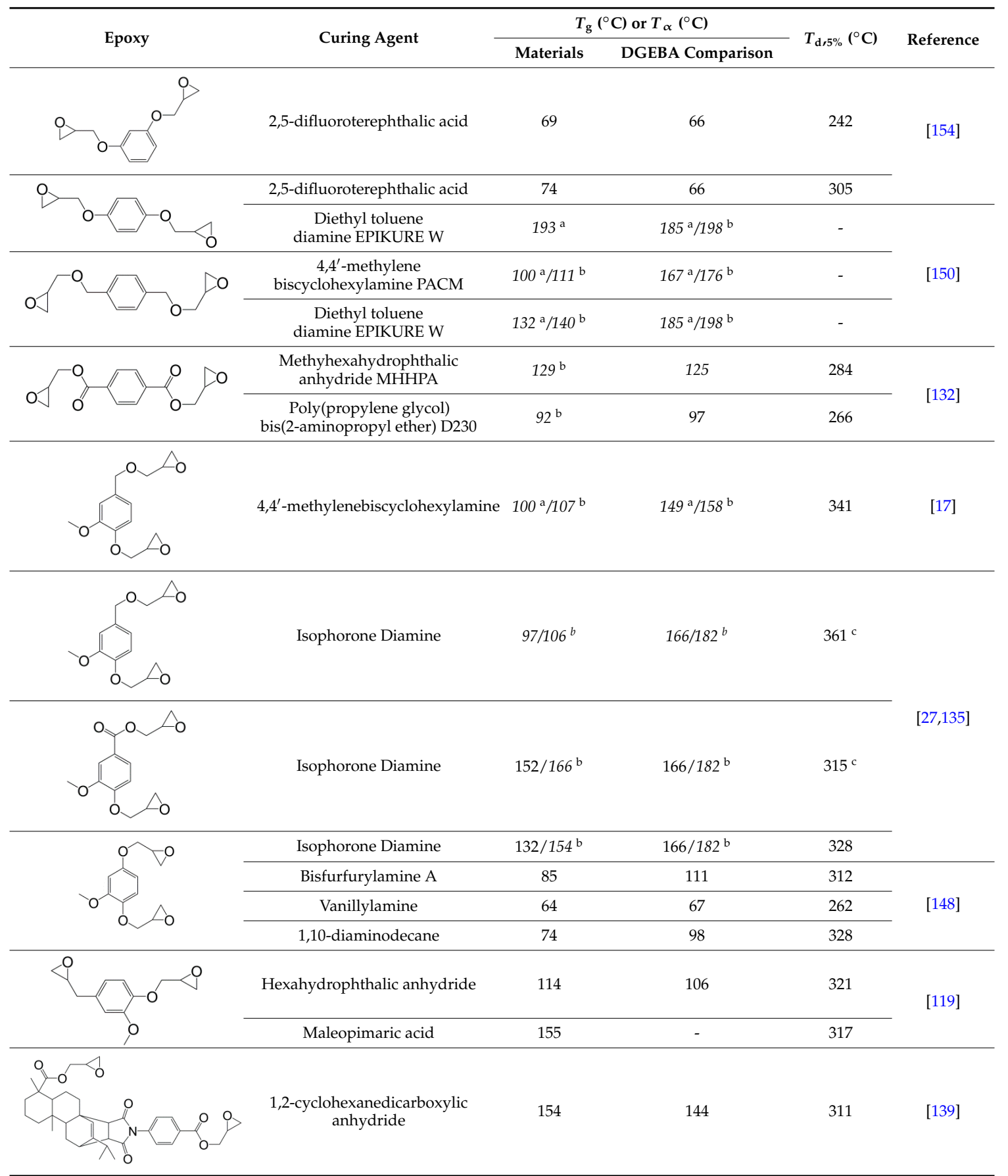

${ }^{\mathrm{a}} T_{\alpha}$ measured by DMA at the peak position of loss modulus curve; ${ }^{\mathrm{b}} T_{\alpha}$ measured by DMA at the maximum of $\tan \delta ;{ }^{c} \mathrm{~T}_{\mathrm{d}, 50 \%}$. 
Table 2. Mono-aromatic, poly-epoxy resins and thermal properties of the cured materials. $T_{\mathrm{g}}$ values are indicated in plain text, $T_{\alpha}$ are in italics.

\begin{tabular}{|c|c|c|c|c|c|}
\hline \multirow{2}{*}{ Epoxy } & \multirow{2}{*}{ Curing Agent } & \multicolumn{2}{|c|}{$T_{\mathrm{g}}\left({ }^{\circ} \mathrm{C}\right)$ or $T_{\alpha}\left({ }^{\circ} \mathrm{C}\right)$} & \multirow{2}{*}{$T_{\mathrm{d}, 5 \%}\left({ }^{\circ} \mathrm{C}\right)$} & \multirow{2}{*}{ Reference } \\
\hline & & Materials & DGEBA Comparison & & \\
\hline \multirow[t]{5}{*}{$\mathrm{O}_{7}$} & PE-C9-NH2 & $102^{\mathrm{a}}$ & 57 & $266^{c}$ & \multirow{2}{*}{ [141] } \\
\hline & PE-C18-NH2 & $112^{\mathrm{a}}$ & 52 & $283^{c}$ & \\
\hline & Isophorone Diamine & 177 & 157 & $306(10 \%)$ & \multirow{3}{*}{ [142] } \\
\hline & Decane-1,10-diamine & 137 & - & $300(10 \%)$ & \\
\hline & Difurfuryl amine & 134 & - & $290(10 \%)$ & \\
\hline \multirow{10}{*}{$\angle 0$} & Isophorone Diamine & $233^{a}$ & 160 & 300 & [22] \\
\hline & Isophorone Diamine & $176 / 194^{b}$ & $166 / 182^{b}$ & 308 & [148] \\
\hline & $\begin{array}{c}\text { 4,4'-metylene } \\
\text { biscyclohexylamine PACM }\end{array}$ & $71^{\mathrm{a}} / 80^{\mathrm{b}}$ & $167^{\mathrm{a}} / 176^{\mathrm{b}}$ & 303 & \multirow{2}{*}{ [150] } \\
\hline & $\begin{array}{l}\text { Diethyl toluene diamine } \\
\text { EPIKURE W }\end{array}$ & $88^{\mathrm{a}} / 94^{\mathrm{b}}$ & $185^{\mathrm{a}} / 198^{\mathrm{b}}$ & - & \\
\hline & $\begin{array}{l}\text { 5,5'-methylene } \\
\text { difurfurylamine }\end{array}$ & $56^{\mathrm{a} / 62^{\mathrm{b}}}$ & $121^{\mathrm{a}} / 128^{\mathrm{b}}$ & 272 & \multirow{2}{*}{ [151] } \\
\hline & $\begin{array}{l}\text { 5,5'-ethylidene } \\
\text { difurfurylamine }\end{array}$ & $56^{\mathrm{a} / 69^{\mathrm{b}}}$ & $128^{\mathrm{a}} / 142^{\mathrm{b}}$ & 272 & \\
\hline & $\begin{array}{c}\text { methyhexahydrophthalic } \\
\text { anhydride MHHPA }\end{array}$ & $152^{\mathrm{b}}$ & 125 & 293 & \multirow[b]{2}{*}{ [132] } \\
\hline & $\begin{array}{c}\text { poly(propylene glycol) } \\
\text { bis(2-aminopropyl ether) } \\
\text { D230 }\end{array}$ & $101^{\mathrm{b}}$ & 97 & 267 & \\
\hline & $\begin{array}{l}\text { 4-methyl hexahydrophthalic } \\
\text { anhydride }\end{array}$ & $78-92$ & - & $246-316$ & [153] \\
\hline & & & & & \\
\hline
\end{tabular}

\subsection{Di-Aromatic Epoxy Compounds}

Its bisphenolic structure provides BPA with high thermo-mechanical properties but also toxicity. In an attempt to mimic but alter the BPA structure to match its qualities but not its defaults, researchers have developed various di-aromatic derivatives based on bio-resources. The diaromatic glycidyl ether compounds are defined as having strictly two benzene rings bearing two or more epoxy groups per molecule. As the spacer between these two aromatic rings plays an important role in the estrogenic disruption of BPA, the epoxy monomers will be presented in the following sections according to the number of atoms between the two aromatic moieties: (i) two benzene rings without spacer; (ii) separated by one atom; (iii) separated by two atoms and (iv) separated by long spacers. 


\subsubsection{Two Aromatic Rings without Spacer}

Grelier et al. [155] synthesized a diglycidyl ether derivative (24) from the bio-based but highly toxic for the environment (H411) 2,6-dimethoxyphenol using a three-steps pathway: (i) enzymatic coupling using laccase from Tramates versicolor; (ii) reduction of the carbon-oxygen double bonds into alcohols and (iii) $\mathrm{O}$-glycidylation with epichlorohydrin (Scheme 9). The di-epoxy monomer obtained was crosslinked using isophorone diamine yielding a material that exhibits a $T_{\mathrm{g}}$ of $126^{\circ} \mathrm{C}$ and a good thermal stability with a $T_{\mathrm{d}, 5 \%}$ of $312^{\circ} \mathrm{C}$. Unfortunately, no DGEBA comparison was provided.

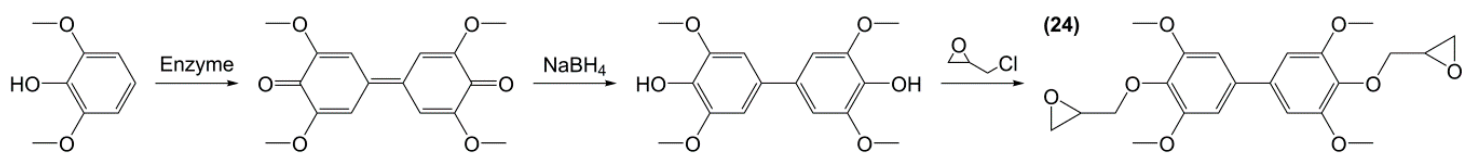

Scheme 9. Synthetic pathway developed by Grelier et al. [155] to obtain diphenolic derivatives from 2,6-dimethoxyphenol.

Following this method, the same team synthesized di-phenols from vanillin [156] (Scheme 10). A methylation step using methyl iodide can be applied prior to the reduction in order to obtain di-functional derivatives. No epoxides were synthesized from these compounds but a simple glycidylation step could easily lead to potential bio-based monomers.

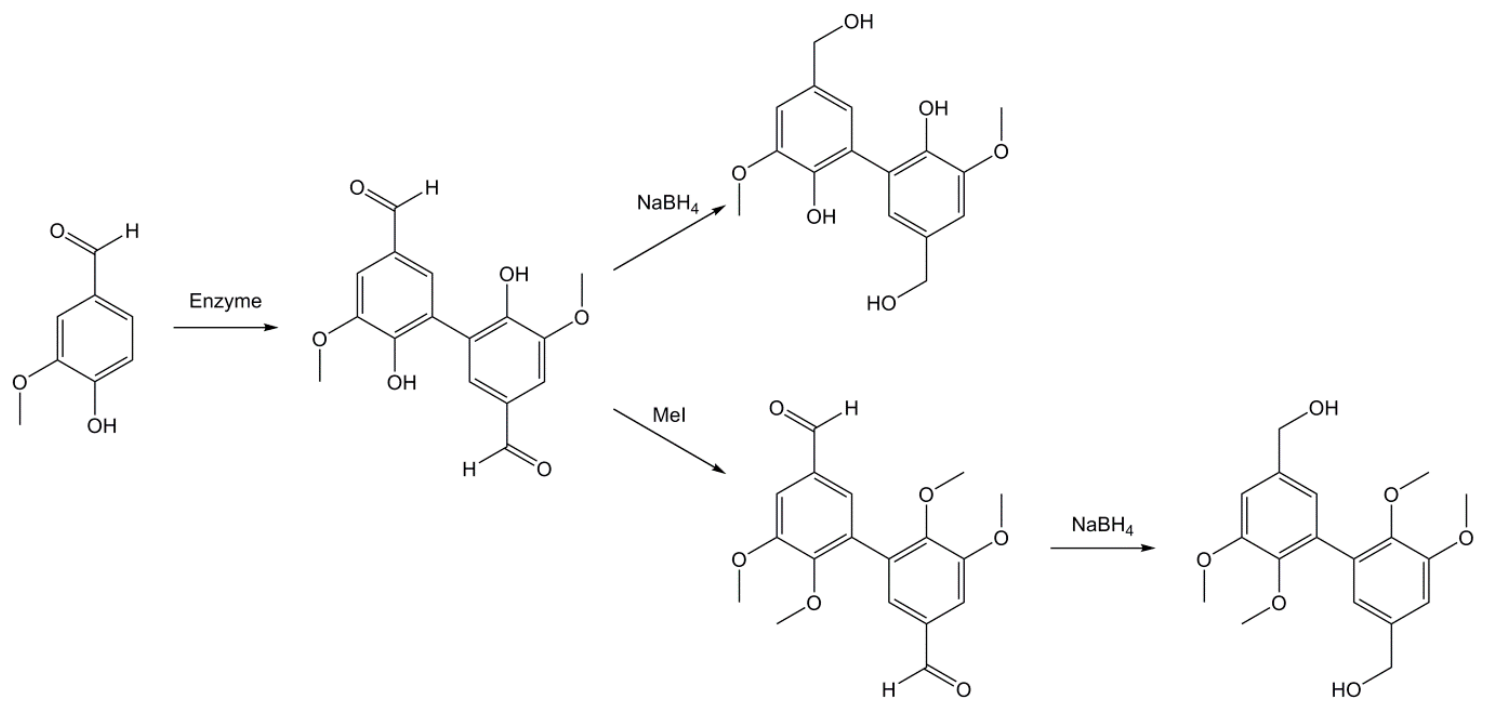

Scheme 10. Synthetic pathway developed by Grelier et al. [156] to obtain diphenolic derivatives from vanillin.

\subsubsection{Two Aromatic Rings Separated by One Atom}

Hernandez et al. [17] recently synthesized epoxy resins by a two-steps pathway involving the electrophilic condensation of vanillyl alcohol and guaiacol, a mono phenolic derivative that can be obtained in large quantities when carrying out the pyrolysis of lignin. This original method is an interesting alternative to the use of formaldehyde, especially for the synthesis of an analogue to bisphenol F. The obtain bis-guaiacol was then glycidylated (25) (Figure 19) and cured with 4, $4^{\prime}$-methylene-biscyclohexylamine (Amicure PACM), yielding a material with a $T_{\mathrm{g}}$ value of $111^{\circ} \mathrm{C}$ compared to $158^{\circ} \mathrm{C}$ for the DGEBA-based material and a slightly lower thermal stability. 
(25)<smiles>COc1cc(Cc2ccc(OCC3CO3)c(OC)c2)ccc1OCC1CO1</smiles><smiles>Cc1cc(Cc2cc(C)c(OCC3CO3)cc2C(C)C)c(C(C)C)cc1OCC1CO1</smiles>

(28)<smiles>Cc1cc(Cc2cc(C)c(OCC3CO3)c(C)c2)cc(C)c1OCC1CO1</smiles>

(26)<smiles>[R]OC(=O)CCCC(C)(c1ccc(OCC2CO2)cc1)c1ccc(OCC2CO2)cc1</smiles>

(29)

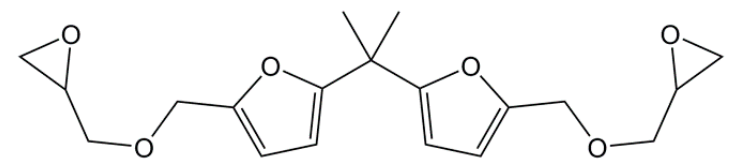

Figure 19. Bio-based di-aromatic epoxy derivatives with a single carbon atom spacer.

$N$-alkyl diphenolate diglycidyl ethers (26) were synthesized by Maiorana et al. [157] in yields ranging from $85 \%$ to $97 \%$ in a two-step pathway using diphenolic acid. First, it was esterified with various alcohols and then glycidylated using epichlorohydrin. The advantage of these epoxides is their liquid state at room temperature and the possibility to have fully bio-based materials. In fact, levulinic acid is produced from cellulose by the acid hydrolysis of $C_{6}$ sugars at the pilot plant scale by Biofine [110] and Segetis [158]. The materials cured with isophorone diamine showed glass transition temperatures in between 86 and $158{ }^{\circ} \mathrm{C}$, depending of the alkyl chain, which is lower than that of DGEBA-based equivalents $\left(165^{\circ} \mathrm{C}\right) . T_{\mathrm{g}}$ decreases with increasing alkyl chain length. No trend was observed regarding storage modulus or tensile strength but materials exhibited mechanical properties similar to DGEBA-based materials and slightly lower thermal stability.

Harvey et al. [117] synthesized di-epoxides (27) through methylene bridging between two carvacrol molecules with 1,3,5-trioxane in dilute $\mathrm{HCl}$ at elevated temperature (Figure 19) and O-glycidylation using epichlorohydrin, with an overall yield of $42 \%$. The resulting monomer was cured with 4,4'-diaminodiphenyl methane and 4,4'-methylene bis(5-isopropyl-2-methylaniline), also prepared from $p$-cymene [116]. The ortho-methylene substituents led to lower degree of cure and higher moisture resistance, and likely lower hydrolysis. The obtained materials showed glass transition temperatures ranging from 143 to $161{ }^{\circ} \mathrm{C}$, which is slightly lower than DGEBA-based materials. When this di-epoxide was cured with 4,4'-diaminodiphenyl methane and compared with diglycidyl ether of tetramethylbisphenol $\mathrm{F}$, the material based on the former showed lower $T_{\mathrm{g}}$ than the latter, up to $23{ }^{\circ} \mathrm{C}$.

Diglycidyl ether of tetramethylbisphenol F (28) was prepared in a two-step synthesis route from 2,6-dimethylphenol and the mutagenic and carcinogenic (H341-350) formaldehyde: (i) aldol condensation reaction between formaldehyde and two molecules of 2,6-dimethylphenol followed by (ii) the direct $O$-glycidylation using epichlorohydrin, with an overall yield of $79 \%$ [159]; The $T_{\mathrm{g}}$ of the material cured with $4,4^{\prime}$-diaminodiphenyl methane showed a high $T_{\mathrm{g}}$ value, up to $184{ }^{\circ} \mathrm{C}$. When this epoxide was compared with its non-spacer analogue, 3,3',5,5'-tetramethyl-4,4'-biphenol, the additional methylene spacer led to a slight decrease of the glass transition temperature, up to $15^{\circ} \mathrm{C}$ lower.

Diglycidyl ether of bisfuran (29) was prepared in a four-step synthesis from the bio-based 2-furoic acid and acetone: (i) protection of the carboxylic groups using methanol; (ii) coupling of two resulting molecules in the presence of acetone and concentrated sulfuric acid; (iii) reduction of the ester groups 
using lithium aluminum hydride and then; (iv) direct $O$-glycidylation of the di-alcohol, with an overall yield of $48 \%$ [113]. However, no materials have been prepared from this epoxy resin.

Meylemans et al. [160] proposed an interesting strategy to synthesize di-phenols from creosol, a phenolic derivative coming from the reduction of vanillin (Figure 20). Through $\mathrm{Zn}(\mathrm{AcO})_{2}$ or acid catalyzed coupling with aldehydes, they obtained two different di-phenol suitable for epoxide synthesis. Unfortunately, no glycidylation step was carried out on these original compounds, although the use of bio-based aldehydes such as benzaldehyde may produce highly bio-sourced monomers as well as greatly influence the mechanical and thermal properties. However, despite the presence of methoxy moieties and a meta substitution, the di-phenol derivatives exhibit a structure very close to bisphenol $\mathrm{E}$ and $\mathrm{F}$, according to the aldehyde chosen, thus requiring toxicological studies to determine their potential dangerousness or estrogen disruptor behavior.<smiles>[R][CH]C([R])c1cc(C)cc(OC)c1O</smiles>

Figure 20. Creosol-based di-phenolic derivative synthesized by Meylemans et al. [160].

\subsubsection{Two Aromatic Rings Separated by Two Atoms}

Duann et al. [161] prepared a bis-phenolic glycidylated derivative by reacting $p$-aminophenol and $p$-hydroxybenzaldehyde prior to a direct epoxidation with epichlorohydrin (30) (Figure 21). $p$-hydroxybenzaldehyde can be obtained from biomass by depolymerizing lignin [162] but to our knowledge no bio-based commercial $p$-aminophenol is currently available. However, $\mathrm{Ng}$ et al. [163] claimed in a patent to have developed a process for producing this compound using genetically engineered microorganisms and biomass-based sugars, possibly providing this resin with a high renewability percentage. After curing with $4,4^{\prime}$-diamino diphenyl methane, they obtained a material with a $T_{\mathrm{g}}$ of $200{ }^{\circ} \mathrm{C}$ and a temperature of $5 \%$ weight loss under air of $342{ }^{\circ} \mathrm{C}$. Unfortunately, no comparison with a DGEBA-based material was provided to determine the role of the carbon-nitrogen double-bond on the thermal and mechanical properties.

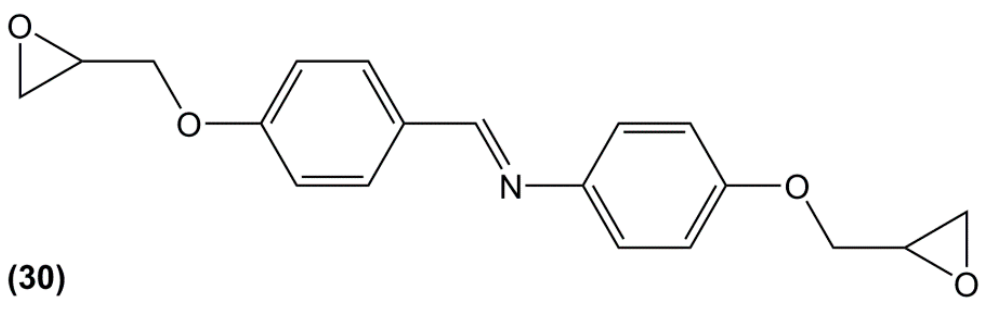

Figure 21. Epoxy resin based on $p$-aminophenol and $p$-hydroxybenzaldehyde synthesized by Duann et al. [161].

Using vanillin as a starting material, Harvey et al. [164] synthesized a di-phenol stilbene using titanium chloride and magnesium, and further hydrogenated it on platinum oxide (Scheme 11). These compounds were turned into cyanates and used to obtain polycyanurates, but no glycidylation step has been considered by the authors despite the interesting potential of these molecules for di-epoxy monomers. 
<smiles>COc1cc(/C=C/c2ccc(CCc3ccc(O)c(OC)c3)cc2OC)ccc1O</smiles>

Scheme 11. Synthesis of di-phenolic compounds from vanillin according to Harvey et al. [164].

\subsubsection{Two Aromatic Rings Separated by More Than Two Atoms}

The small size of BPA allows it to mimic the natural estrogen $17 \beta$-estradiol and enter the estrogen receptor pocket. Thus, by increasing the length of the spacer, it may be possible to decrease the activity of the epoxy monomer precursors. In this part, all monomers with long aliphatic or cycloaliphatic spacer will be presented, including both di- and poly-epoxy monomers.

\section{Di-Epoxy Monomers}

Recently, Zou et al. [165] synthesized bio-based epoxy monomers by coupling glycidylated eugenol via photo-initiated thiol-ene reaction using three different aliphatic di-thiols (31) (Figure 22). The resins were cured by 4,4'-diaminodiphenylmethane and the resulting materials exhibited $T_{\mathrm{g}}$ and $T_{\alpha}$ values ranging from 39 to $60^{\circ} \mathrm{C}$ by DSC and 54 to $70{ }^{\circ} \mathrm{C}$ by DMA, respectively. As expected, the glass transition decreased when increasing the di-thiol chain length.

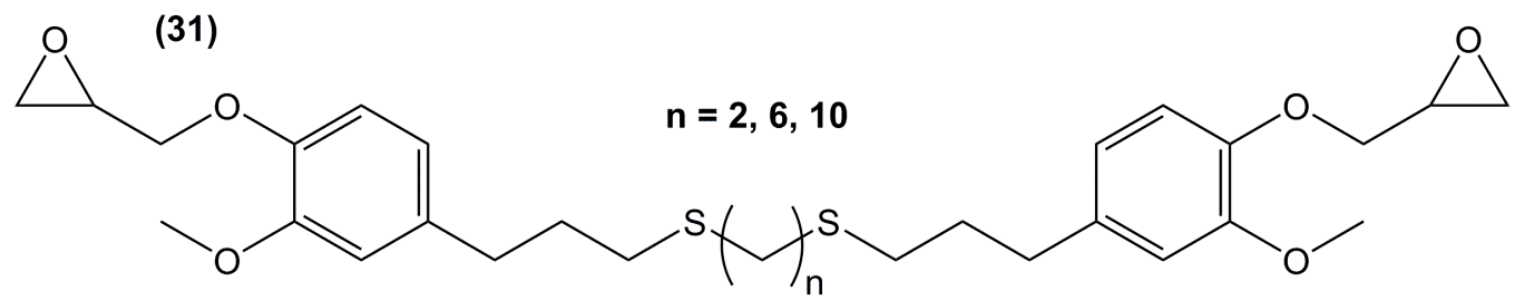

Figure 22. Eugenol-based epoxy prepolymers synthesized by Zou et al. [165].

Following the same synthetic pathway, Maiorana et al. [123] and Menard et al. [166] synthesized bio-based bis-ferulate epoxy monomers (32) (33) and (34) (Scheme 12) via a three step synthetic pathway: (i) synthesis of ethyl ferulate by reacting with $\mathrm{HCl}$ and hydrogenating over Pd/C; (ii) enzyme-catalyzed transesterification with various bio-based diols including $n$-alkyl diols and isosorbide or transamidification with 1,4-diaminobutane; and (iii) $O$-glycidylation with epichlorohydrin in high yields. The epoxy monomers were cured by isophorone diamine, 1,10-diaminodecane and difurfurylamine. Regarding the thermosets based on the $n$-alkyl bis-ferulates and IPDA, the $T_{\alpha}$ values ranged from 50 to $65^{\circ} \mathrm{C}$ and decreased while increasing the diol chain length, compared to $170{ }^{\circ} \mathrm{C}$ for DGEBA-based material. The change of ester to amide bonds lead to higher $T_{\mathrm{g}}$ values thanks to the hydrogen bonding induced by the nitrogen atoms. These values were roughly similar to those obtained with the isosorbide derivative, the cycloaliphatic structure of which brought more rigidity to the polymeric network. However, none of these materials could compete with DGEBA-based resources in terms of $T_{\mathrm{g}} / T_{\alpha}$. An interesting point to mention nonetheless is that Maiorana et al. [123] also focused on the degradability of the obtained materials for thermosets recyclability issues, and studied the estrogenic activity of bisferulates compared to bisphenol $\mathrm{A}$ and $17 \beta$-estradiol. The $n$-alkyl bis-ferulates derivatives showed no significant estrogenic activity for ER $\alpha$ 
at concentrations where bisphenol A does, highlighting the potential of these compounds as a safer substitute for BPA.

In a similar way, Aouf et al. [40] synthesized glycidylated bio-based bis-vanillic acid (35) in a three-steps pathway: (i) synthesis of bis-vanillic acid by reaction with 1,5-dibromopentane; (ii) allylation of the hydroxyl functions with allyl bromide and (iii) epoxidation of the allyl bond with an enzymatic catalyst (Figure 23). Unfortunately, no materials were synthesized with these di-epoxy monomers.

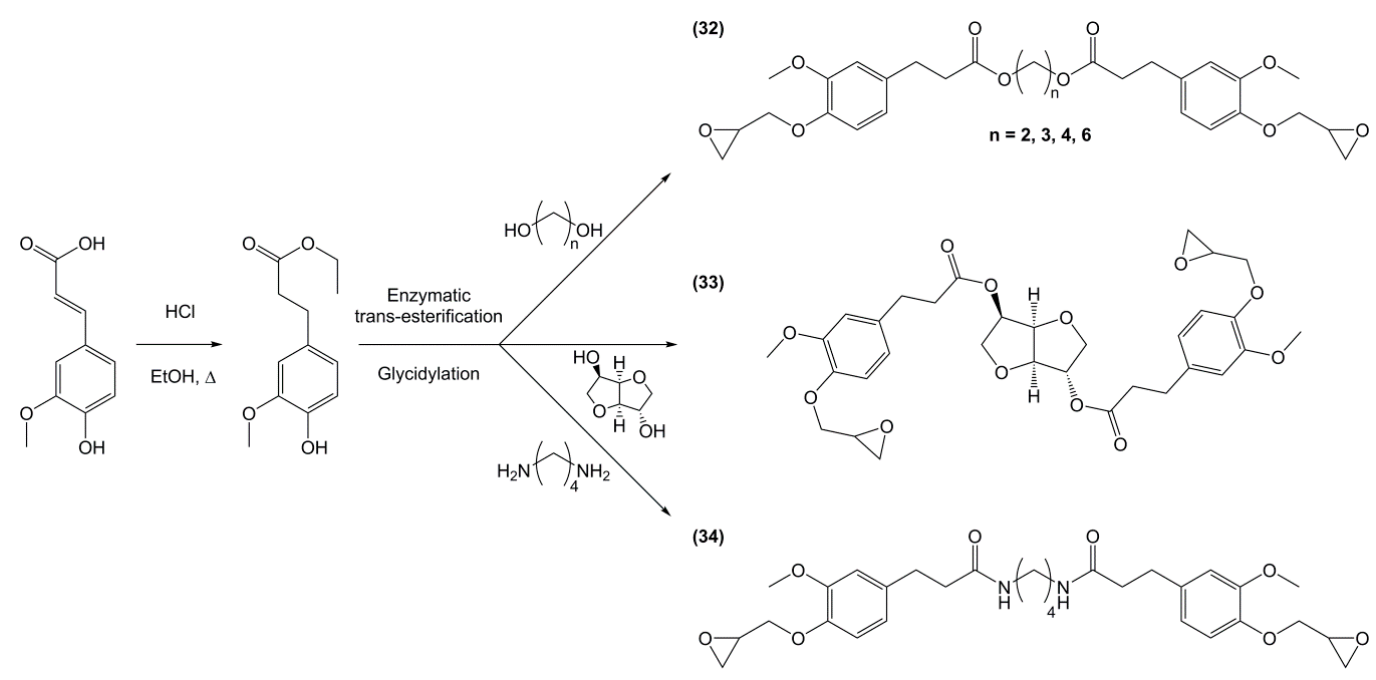

Scheme 12. Synthetic pathway to obtain bio-based di-epoxy monomers from ferulic acid proposed by Maiorana et al. [123] and Ménard et al. [166].

(35)<smiles>COC(=O)c1ccc(OCC2CO2)c(OC)c1</smiles>

(36)<smiles>CCCOC(=O)c1ccc(OCC2CO2)cc1</smiles>

Figure 23. Di-epoxy monomers with longer ester spacers between the aromatic rings.

Fourcade et al. [167] used 1,6-hexanediol to synthesize an epoxy resin using a two-steps synthetic route: (i) phenolization of the 1,6-hexanediol using ethyl-4-hydroxybenzoate with $92 \%$ of yield; and (ii) direct $O$-glycidylation using epichlorohydrin in the presence of sodium carbonate (36) (Figure 23). The resulting epoxide was used as a DGEBA diluent and blended with 50\%-90\% of DGEBA and then cured with dicyandiamide. The glass transition temperature of the blend materials ranged from 77 to $109^{\circ} \mathrm{C}$, decreasing when increasing the amount of aliphatic epoxide. Materials exhibited high thermal stabilities under air, but unfortunately no sample without DGEBA was mentioned. While the 1,6-hexanediol used by the authors was oil-based, it can be obtained by hydrogenation of adipic acid coming from different biomass such as glucose, lignin and fatty acids [168]. It is considered lowly 
toxic [169] and is not labelled as carcinogenic or mutagen. Ethyl-4-hydroxybenzoate is obtained by esterification of 4-hydroxybenzoic acid, a naturally occurring product synthesized industrially from phenol, carbon dioxide and bio-ethanol. Moreover, the authors used epichlorohydrin from glycerol (Epicerol ${ }^{\circledR}$ process) making the resins possibly highly renewable, although no value was given.

Diglycidyl ether derivatives including spiro-ring as spacer can be prepared in a two-step pathway from non-toxic, bio-based reactants, e.g., vanillin $[27,135,170,171]$ and pentaerythritol [167]: (i) condensation of both starting substances and (ii) direct $O$-glycidylation using epichlorohydrin in the presence of sodium hydroxide. However, no other detail, such as reaction yield could be found [172]. In 1986 and 1987, Ochi et al. [173] investigated a series of diglycidyl ether containing spiro-ring building blocks (37) (38) (39), as shown in Figure 24. Materials cured with hexahydrophthalic anhydride showed similar or higher glass transition temperatures than that of their DGEBA counterparts. Curing with more rigid anhydrides, e.g., phthalic anhydride and nadic anhydride allowed to slightly increase $T_{\mathrm{g}}$, in comparison to hexahydrophthalic anhydride.

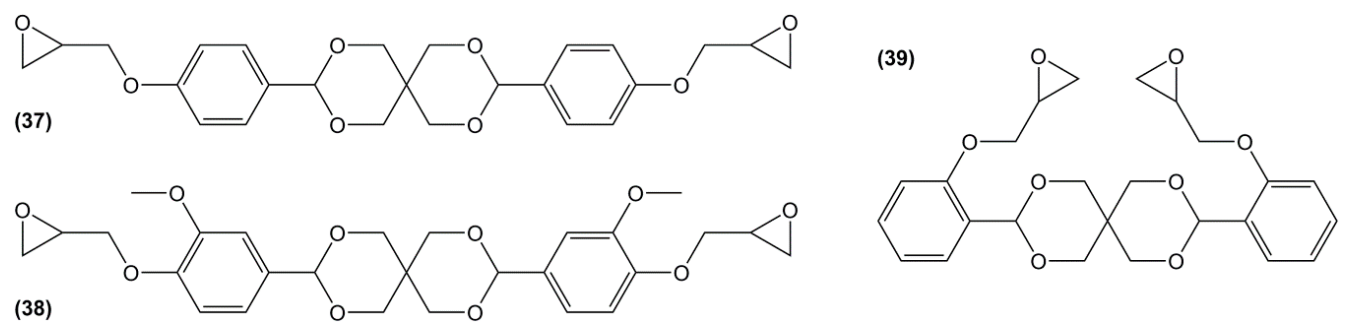

Figure 24. Diglycidyl ether derivatives containing spiro rings.

Rao and Samui [174] synthesized diepoxy monomers including bisbenzylidene segments by reaction between vanillin or syringaldehyde with acetone (40) and cycloaliphatic ketones (41) followed by glycidylation with epichlorohydrin (Scheme 13). These monomers were used to synthesize linear polyesters for photoactive liquid crystal applications but also reacted with benzene-1,3,5-tricarboxylic acid to obtain dendrimers, although their protocol seems more likely to yield crosslinked materials. No data on potential thermo-mechanical properties is thus mentioned.

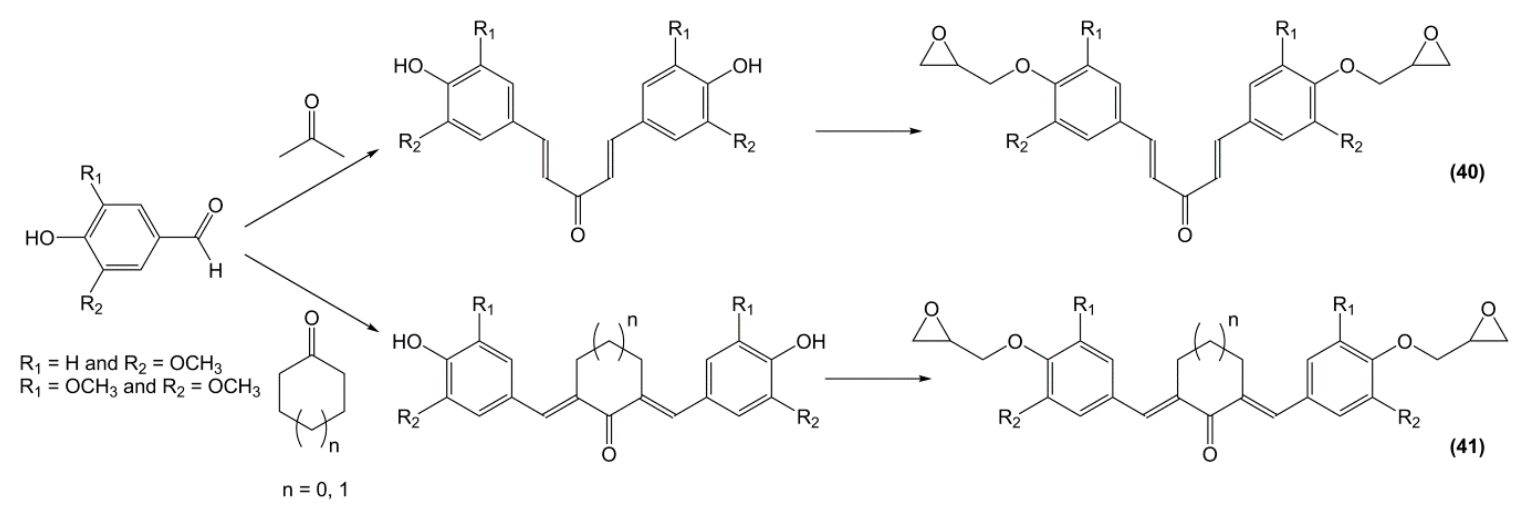

Scheme 13. Synthesis of di-epoxy monomers from vanillin and syringaldehyde with acetone or cycloaliphatic ketones according to Rao and Samui [174].

\section{Poly-Epoxy Monomers}

Triglycidyl ether of polyphenol (42) (Figure 25) was synthesized in a two-steps pathway from resorcinol and acetone: a coupling reaction followed by direct $O$-glycidylation using epichlorohydrin [175]. The glass transition temperature of the resulting material cured with diaminodiphenyl sulfone was not observed neither in DSC, nor in DMA, up to $300^{\circ} \mathrm{C}$. The authors concluded that the $T_{\mathrm{g}}$ was above $300{ }^{\circ} \mathrm{C}$, thus making it much higher than that of DGEBA-based 
material. The three epoxy groups and the rigidity of the cyclic backbone may in fact explain such a result.<smiles>CC1(C)CC(C)(C)c2ccc(OCC3CO3)cc2O1</smiles>

Figure 25. Triglycidyl ether derivative based on resorcinol and acetone.

Aouf et al. [176] studied hydrolysable tara tannins as potential candidates for a source of phenolic moieties. These galloylquinic acid oligomers were first depolymerized by tannase-assisted hydrolysis to produce mainly gallic acid and galloylquinic acid. The epoxidation of this mixture was carried out by direct $O$-glycidylation, leading to galloylquinic esters and glycidylated dimerized gallic moieties (Figure 26). The obtained monomer mixture was cured using isophorone diamine and the resulting material showed a $T_{\mathrm{g}}$ up to $129^{\circ} \mathrm{C}$, which is $20^{\circ} \mathrm{C}$ lower than that of DGEBA-based materials in the same conditions. The presence of esters bonds may however make these thermosets more sensitive to hydrolysis and favour the use of condensed instead of hydrolysable tannins.
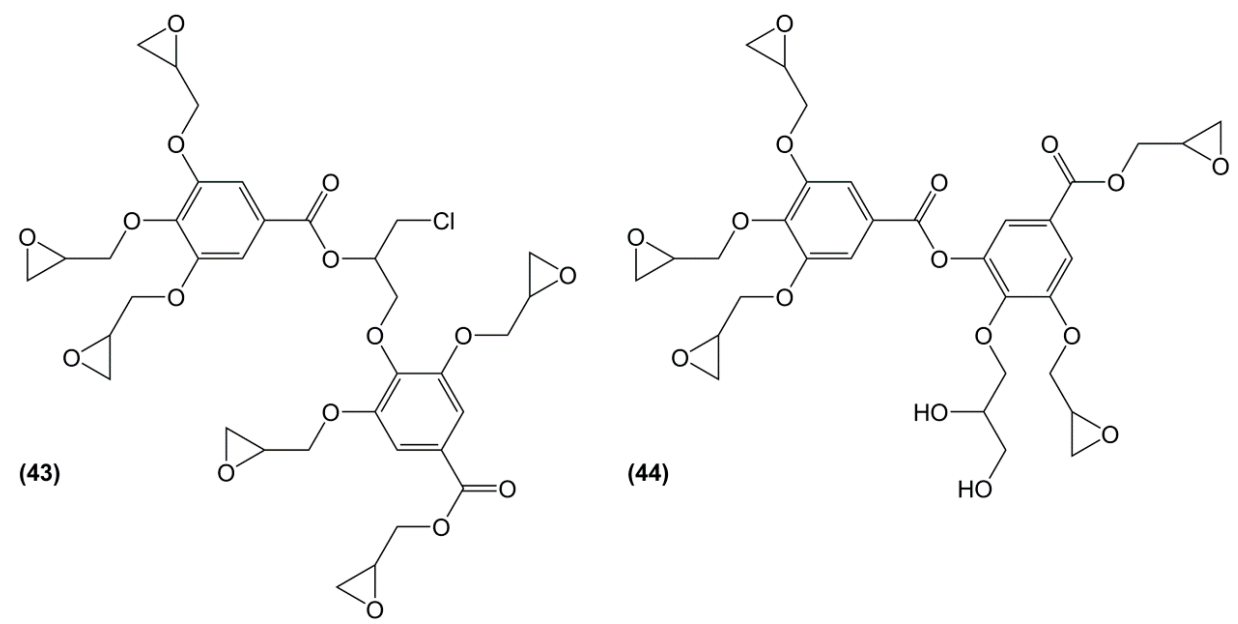

Figure 26. Main oligomers obtained from the glycidylation of depolymerized tara tannins by Aouf et al. [176].

For this reason, Nouailhas et al. [128,177] focused their research on catechin, one of the constitutive units of condensed tannins. Although it is not yet bio-based, it can be obtained by acid-depolymerization as previously described (Section 4.2.). The direct O-glycidylation of catechin (Figure 27) led mainly to the tetraglycidylated catechin (45) (46\%) and to two di-glycidylated benzodioxane derivatives (46), with a yield of $18 \%$ and $15 \%$, respectively. As the mixture was a solid at room temperature, it was mixed with 25 and $50 \%$ of DGEBA as a reactive diluent and cured with Epamine PC 19, which is composed of benzyl alcohol, 1,3-bis(aminomethyl)benzene, 3-amino-methyl-3,5,5-trimethylcyclohexylamine and BPA-epichlorohydrin polymer. The materials based on the $50 \%$ and $75 \%$ blends of glycidylated catechin exhibited slightly lower and $10{ }^{\circ} \mathrm{C}$ higher $T_{\mathrm{g}}$ than DGEBA-based materials, respectively. These results may seem surprising as the introduction of tetra-epoxy monomers with the catechin rigid structure was expected to increase glass transition temperature. However, the role of the di-epoxy benzodioxane derivative is not elucidated and may explain these results. 

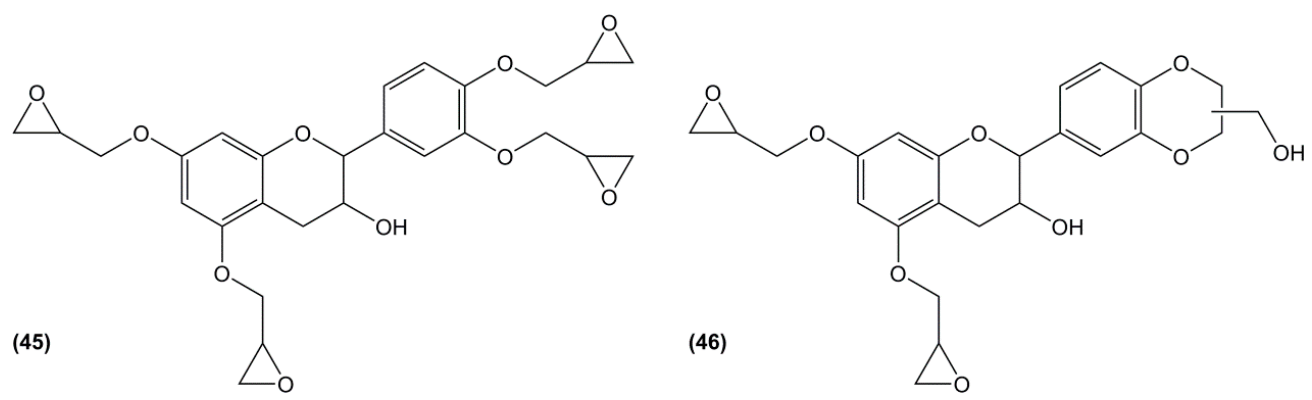

Figure 27. Epoxy monomers obtained by glycidylation of catechin according to Nouailhas et al. [128].

\subsubsection{Conclusions}

A wide range of di-aromatic bio-based epoxy monomers has been synthesized and cured over the past years with most of them exhibiting interesting and varied properties in terms of glass transition temperature and thermal stability. Shrewd strategies have been developed to slightly or largely step away from the detrimental structure of BPA, but similarly to mono-aromatic compounds, very few were studied for their estrogen activity. The following tables (Tables 3-5) gather the known data on cured materials based on the di-aromatic di- and poly-epoxy monomers.

Table 3. Di-epoxy resins with two aromatic rings separated by one atom, and thermal properties of the cured materials.

\begin{tabular}{|c|c|c|c|c|c|}
\hline \multirow{3}{*}{ Epoxy } & \multirow{2}{*}{ Curing Agent } & \multicolumn{2}{|c|}{$T_{\mathrm{g}}\left({ }^{\circ} \mathrm{C}\right)$ or $T_{\alpha}\left({ }^{\circ} \mathrm{C}\right)$} & \multirow{2}{*}{$T_{\mathrm{d}, 5 \%}\left({ }^{\circ} \mathrm{C}\right)$} & \multirow{2}{*}{ Reference } \\
\hline & & Materials & DGEBA Comparison & & \\
\hline & 4,4'-methylene-biscyclohexylamine & $104^{\mathrm{a} / 111^{\mathrm{b}}}$ & $149^{\mathrm{a}} / 158^{\mathrm{b}}$ & 363 & [17] \\
\hline
\end{tabular}
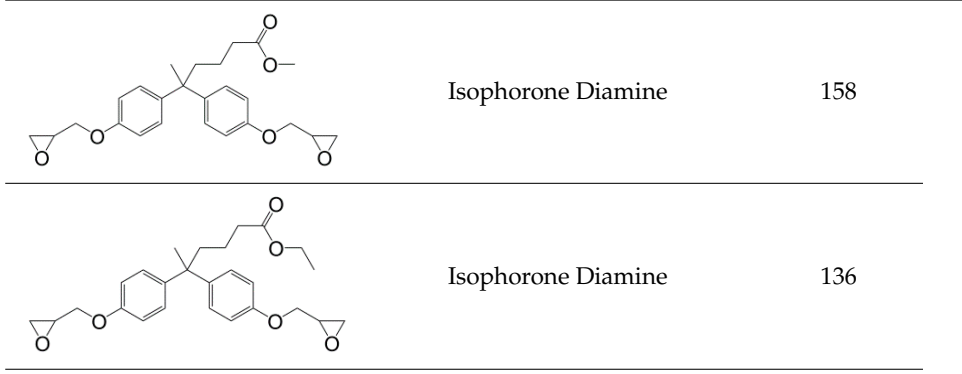

Isophorone Diamine

Isophorone Diamine

\begin{tabular}{l} 
4,4'-diaminodiphenyl methane \\
\cline { 2 - 5 }
\end{tabular}

${ }^{\mathrm{a}} T_{\alpha}$ measured by DMA at the peak position of loss modulus curve; ${ }^{\mathrm{b}} T_{\alpha}$ measured by DMA at the maximum of $\tan \delta ;{ }^{c} T_{\mathrm{d}}$ under air flow.

361 
Table 4. Di-epoxy monomers with two aromatic rings separated by more than one atom exhibiting ester or amide bonds, and thermal properties of the cured materials.

\begin{tabular}{|c|c|c|c|c|c|}
\hline \multirow{2}{*}{ Epoxy } & \multirow{2}{*}{ Curing Agent } & \multicolumn{2}{|c|}{$T_{\mathrm{g}}\left({ }^{\circ} \mathrm{C}\right)$ or $T_{\alpha}\left({ }^{\circ} \mathrm{C}\right)$} & \multirow{2}{*}{$T_{\mathrm{d}, 5 \%}\left({ }^{\circ} \mathrm{C}\right)$} & \multirow{2}{*}{ Reference } \\
\hline & & Materials & DGEBA Comparison & & \\
\hline & $\begin{array}{l}\text { Isophorone } \\
\text { diamine }\end{array}$ & $66^{\mathrm{b}}$ & $170^{\mathrm{b}}$ & 300 & [123] \\
\hline \multirow{3}{*}{ of } & $\begin{array}{l}\text { Isophorone } \\
\text { diamine }\end{array}$ & $51 / 61^{b}$ & $150 / 174^{b}$ & 314 & \multirow{3}{*}{ [166] } \\
\hline & 1,10-diaminodecane & $33 / 33^{b}$ & $98 / 97^{b}$ & 314 & \\
\hline & Difurfurylamine & $32 / 41^{b}$ & $92 / 110^{\mathrm{b}}$ & 306 & \\
\hline$\sigma^{0}$ & $\begin{array}{l}\text { Isophorone } \\
\text { diamine }\end{array}$ & $50^{\mathrm{b}}$ & $170^{b}$ & 331 & [123] \\
\hline & $\begin{array}{l}\text { Isophorone } \\
\text { diamine }\end{array}$ & $85 / 99^{b}$ & $150 / 174^{\mathrm{b}}$ & 295 & \multirow{6}{*}{ [166] } \\
\hline & 1,10-diaminodecane & $54 / 68^{\mathrm{b}}$ & $98 / 97^{b}$ & 292 & \\
\hline & Difurfurylamine & $63 / 85^{b}$ & $92 / 110^{\mathrm{b}}$ & 304 & \\
\hline \multirow{3}{*}{$\mathrm{or}_{\mathrm{O}}$} & $\begin{array}{c}\text { Isophorone } \\
\text { diamine }\end{array}$ & 75 & 150 & 282 & \\
\hline & 1,10-diaminodecane & 69 & 98 & 297 & \\
\hline & Difurfurylamine & 74 & 92 & 271 & \\
\hline
\end{tabular}

${ }^{\text {a }} T_{\alpha}$ measured by DMA at the peak position of loss modulus curve; ${ }^{\mathrm{b}} T_{\alpha}$ measured by DMA at the maximum of $\tan \delta ;{ }^{c} T_{\mathrm{d}}$ under air flow.

Table 5. Di-epoxy monomers with two aromatic rings separated by more than one atom, and thermal properties of the cured materials.

\begin{tabular}{|c|c|c|c|c|c|}
\hline \multirow{2}{*}{ Epoxy } & \multirow{2}{*}{ Curing Agent } & \multicolumn{2}{|c|}{$T_{\mathrm{g}}\left({ }^{\circ} \mathrm{C}\right)$ or $T_{\alpha}\left({ }^{\circ} \mathrm{C}\right)$} & \multirow{2}{*}{$\mathrm{T}_{\mathrm{d}, 5 \%}\left({ }^{\circ} \mathrm{C}\right)$} & \multirow{2}{*}{ Reference } \\
\hline & & Materials & DGEBA Comparison & & \\
\hline 釜 & $\begin{array}{l}\text { 4,4'-Diamino } \\
\text { diphenyl } \\
\text { methane }\end{array}$ & $60 / 70$ & - & - & \multirow{3}{*}{ [165] } \\
\hline & $\begin{array}{l}\text { 4,4'-Diamino } \\
\text { diphenyl } \\
\text { methane }\end{array}$ & $45 / 58$ & - & - & \\
\hline & $\begin{array}{l}\text { 4,4'-Diamino } \\
\text { diphenyl } \\
\text { methane }\end{array}$ & $39 / 54$ & - & - & \\
\hline & $\begin{array}{l}\text { 4,4'-Diamino } \\
\text { diphenyl } \\
\text { methane }\end{array}$ & 200 & - & $341 / 342^{c}$ & [16] \\
\hline & $\begin{array}{l}\text { Hexahydrophthalic } \\
\text { anhydride }\end{array}$ & $134^{\mathrm{b}}$ & $132^{b}$ & - & \multirow{5}{*}{ [173] } \\
\hline & $\begin{array}{l}\text { Phthalic } \\
\text { anhydride }\end{array}$ & $138^{b}$ & - & - & \\
\hline & Nadic anhydride & $147^{\mathrm{b}}$ & - & - & \\
\hline & $\begin{array}{l}\text { Hexahydrophthalic } \\
\text { anhydride }\end{array}$ & $170^{\mathrm{b}}$ & $132^{b}$ & - & \\
\hline & $\begin{array}{l}\text { Hexahydrophthalic } \\
\text { anhydride }\end{array}$ & $149^{b}$ & $132^{b}$ & - & \\
\hline
\end{tabular}

\footnotetext{
${ }^{\text {a }} T_{\alpha}$ measured by DMA at the peak position of loss modulus curve; ${ }^{b} T_{\alpha}$ measured by DMA at the maximum of
} $\tan \delta ;{ }^{\mathrm{c}} T_{\mathrm{d}}$ under air flow. 


\subsection{Polyaromatic Epoxy Compounds}

As observed in the previous parts, it is hard to match up with the properties of DGEBA-based materials, especially in term of glass transition temperature, thus making the use of polyaromatic and possibly poly-epoxy derivatives a viable alternative. Moreover, the direct use of the biomass would avoid the costly and time-consuming depolymerization and purification steps. The next part will present the epoxy prepolymers containing at least three aromatic moieties and two or more epoxy rings.

\subsubsection{Glycidylated Lignin}

Chemical modifications of lignin functional groups were carried out to increase its solubility and chemical reactivity, and thus its range of applications. Among the possible functionalizations, modification of the hydroxyl groups is the most versatile since phenolic hydroxyl groups are the most reactive groups and can significantly affect the chemical reactivity of the materials. Allylation [178], esterification [179,180], phenolation [181] or etherification [172,182-184] of lignin have been widely investigated. However, only few research groups attempted to epoxidize raw depolymerized lignin by direct O-glycidylation.

As the isolation of pure building blocks from lignin is both economically and environmentally costly, Fache et al. [185] developed model mixtures of depolymerization products of lignin from both hardwood and softwood, including for example vanillin, syringaldehyde and their acid equivalents. After a Dakin oxidation to increase the number of reactive hydroxyl groups and an $O$-glycidylation step, the materials cured with IPDA showed interesting thermo-mechanical properties, with $T_{\mathrm{g}}$ values of $99^{\circ} \mathrm{C}$ and $113^{\circ} \mathrm{C}$ for hardwood and softwood model mixtures, respectively. These temperatures remain lower than that of DGEBA-based materials synthesized by the same authors in fairly similar conditions [135], probably due to the mono-epoxy derivatives included in the mixtures. Both materials exhibited a good thermal stability with onset degradation temperatures above $250{ }^{\circ} \mathrm{C}$ under nitrogen atmosphere and high char yields of $20 \%-23 \%$ at $600{ }^{\circ} \mathrm{C}$. This study demonstrated that purification steps are not necessarily required to achieve high-performance epoxy thermosets from biomass.

Ferdosian et al. [186] carried out the glycidylation of de-polymerized organosolv or Kraft lignin with epichlorohydrin and highlighted the presence of epoxy by normalized FTIR. Then, they prepared materials of the resulting epoxidized lignin by curing with aromatic and aliphatic amines to show the influence of the curing agent on the thermal stability. Despite the good thermal stability and very high char rate at $800^{\circ} \mathrm{C}$, no glass transition temperature or mechanical properties were given.

Following the work of Zhao et al. [187], Sun et al. [188] prepared a liquid epoxy resin from phenolated lignosulfonate and focused their study on its curing kinetics with maleic anhydride. No data on the material properties were given.

Kaiho et al. [189] used a three-steps pathway to synthesize lignin-based epoxy resins (Figure 28): (i) selective $\beta-O-4$ bond cleavage of eucalyptus globulus lignin, (ii) transacetalization for the synthesis of spiro rings (47) or annulation to form a phenyl-naphthalene derivative (48) and (iii) O-glycidylation with epichlorohydrin. The obtained resins were cured with phenol novolac yielding materials with glass transition temperatures ranging from 67 to $134^{\circ} \mathrm{C}$ and of $95^{\circ} \mathrm{C}$ for an epoxy/bisphenol A system. As expected from the structures, the more rigid structure of the phenyl-naphthalene lignin epoxy prepolymers lead to higher $T_{\mathrm{g}}$ values and higher flexural strength.

Similarly, Asada et al. [190] used various low molecular weight lignins extracted with methanol to synthesized bio-based epoxy resins. The glycidylation was assessed by FTIR and ${ }^{1} \mathrm{H}$ NMR spectroscopies and four sets of materials were cured using two epoxy resins: glycidylated lignin and an oil-based commercial Epikote 828 (EP828, DGEBA from Japan Epoxy Resins Co. Ltd., Nagoya, Japan) and two phenolic hardeners: non-glycidylated lignin and TD2131 (a phenol novolac from DIC Corp., Tokyo, Japan). The materials exhibited high thermal stabilities with $T_{\mathrm{d}, 5 \%}$ ranging from 259 to $326^{\circ} \mathrm{C}$, still lower than the fully oil-based material $\left(361^{\circ} \mathrm{C}\right)$ but with higher char rates, up to $41 \%$ at $800{ }^{\circ} \mathrm{C}$. Unfortunately, no glass transition temperatures or mechanical properties were provided. It is 
worth noting that the lignin extract insoluble in methanol was enzymatically transformed into glucose, increasing the biomass promotion.
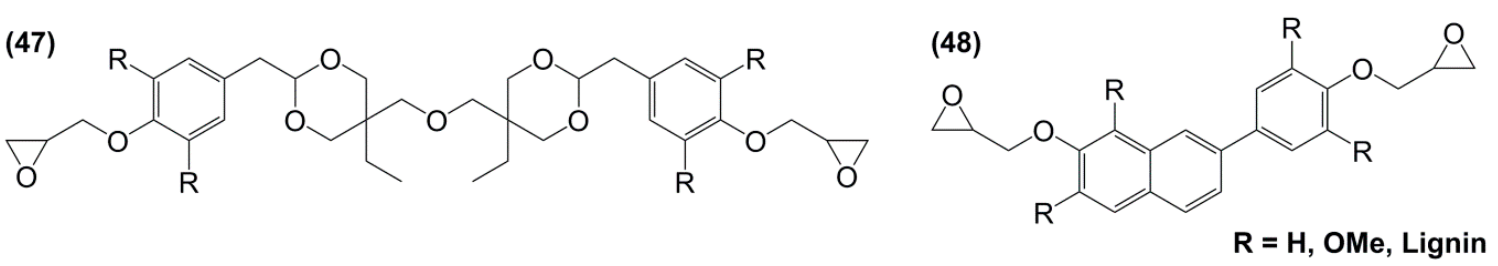

Figure 28. Lignin-based epoxy resins synthesized by Kaiho et al. [189].

Other uses have been found to lignin for the improvement of epoxy resins. Lignin functionalized by a dicarboxylic acid prepared by dimerizing unsaturated fatty acids was considered as a phenolic aldehyde amine curing agent by Fang et al. [191]. Similarly, Engelmann et Ganster [192] blended a low molecular weight lignin fraction with the bio-based tri-glycidylated glycerol for the preparation of composites reinforced with cellulosic fibers.

\subsubsection{Glycidylated Tannins}

Few research papers are devoted to the use of tannins and tannin-based molecules for epoxy materials synthesis compared to lignin ones. Maybe the reduced availability of the former is a key factor in this result, as the complexity and the variability of both these bio-resources seem similar. As previously mentioned before, Aouf et al. [176] considered the hydrolysable tannins from tara as potential precursor for epoxy prepolymer synthesis, but they first carried out a depolymerization to obtain gallic acid mixtures prior to glycidylation. Benyahya et al. [193] focused their work on the inexpensive green tea (Camellia sinensis) tannins, which are condensed tannins mainly composed of epicatechin, catechin dimers and their galloylated equivalents. The tannins extracts were glycidylated with epichlorohydrin and cured with isophorone diamine. The obtained materials exhibited a $T_{\alpha}$ of $142{ }^{\circ} \mathrm{C}$, a value similar to the $140{ }^{\circ} \mathrm{C}$ of the material from IPDA and DER352 (a mixture of DGEBA and DGEBF supplied by Dow (France)). Swelling ratios and soluble fractions of these materials also proved to be very low. Jahanshahi et al. [194,195] recently published two papers on the use of condensed tannins for the synthesis of bio-based materials. In the first one [194], Mimosa (Acacia mearnsii) bark tannins were glycidylated with epichlorohydrin but the epoxy rings were then reacted with acrylic acid for adhesive synthesis. On the contrary, in their second paper, they focused their efforts on the glycidylation optimal parameters and characterization of the epoxy prepolymers, thus very brief results on tensile shear tests of glycidylated tannins mixed with DGEBA were mentioned.

\subsubsection{Glycidylated Cardanol}

To increase the low glass transition temperatures obtained with materials based on glycidylated cardanol, a polyaromatic derivative of it can be designed by a two-steps synthesis, beginning by a phenolation step and followed by direct $O$-glycidylation. The resulting product is idealized by a diepoxidized diaromatic cardanol structure and marketed with the name NC514 by Cardolite. However, Jaillet et al. [196] showed that the commercial product is a mixture (49), in which chains are crosslinked and some epoxy rings are opened, as shown in Figure 29. This product may cause an allergic skin reaction (H317), but can be used as food contact material, according to the supplier.

Epoxy-amine based materials showed moderate glass transition temperature, from 13 to $30{ }^{\circ} \mathrm{C}$ with linear aliphatic diamines [197-199]. The highest $T_{\mathrm{g}}$ was reached when epoxidized cardanol was cured with isophorone diamine, up to $50{ }^{\circ} \mathrm{C}$, which is still $100{ }^{\circ} \mathrm{C}$ lower than that of DGEBA-based material [196]. Nevertheless, the fatty chain of the epoxidized cardanol allows more flexibility, conferring mechanical properties suitable for particular coating applications. Glycidyl ether 
groups have also been converted to methacrylate, allowing radical polymerization for other coating applications [200,201].

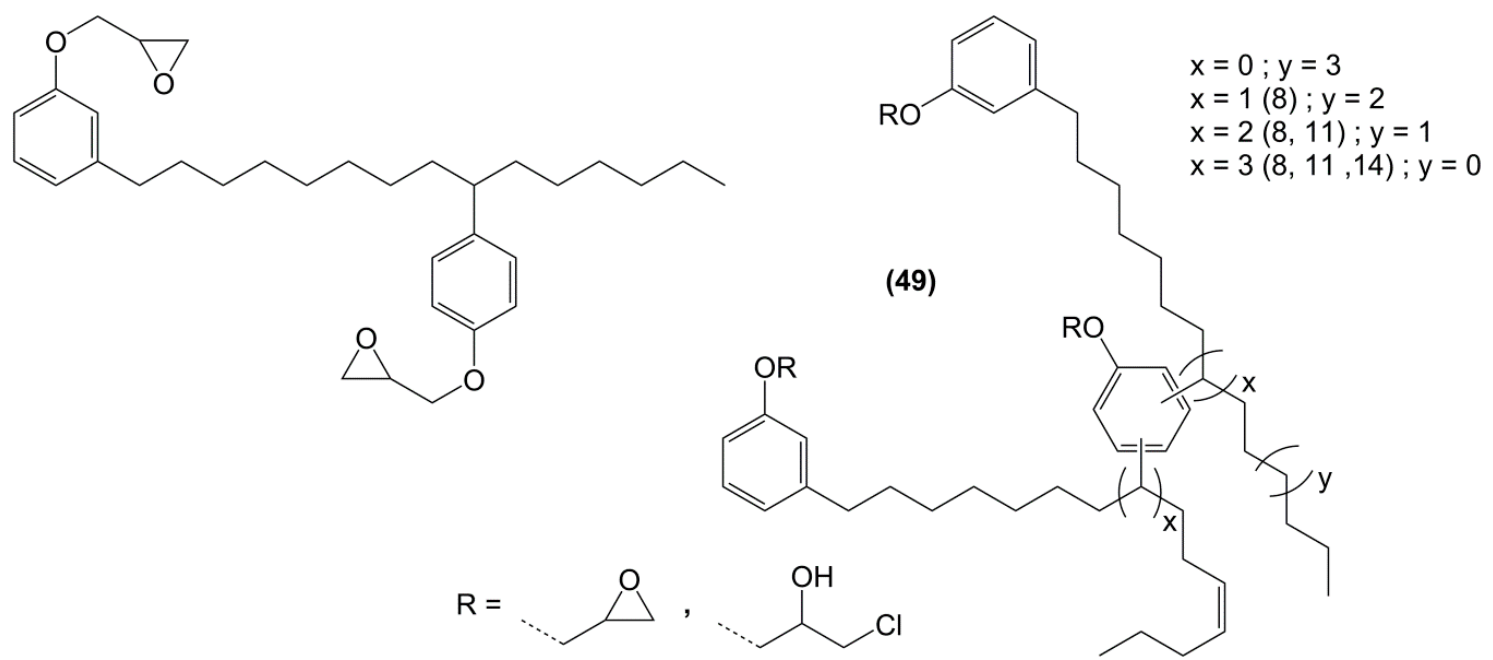

Figure 29. Idealized structure of phenolated cardanol (left) and real structure (49) of NC514 by Cardolite. The numbers between brackets indicate the locations of the phenol moieties along the aliphatic alkyl chain.

\subsubsection{Other Bio-Based Poly-Aromatic Monomers}

Fourcade et al. [167] applied the same strategy as previously described (see Section 5.2.2.) on various aliphatic polyols (Scheme 14). Glycerol (50) and sorbitol (51) are bio-based precursors, pentaerythritol (52), di-pentaerythritol (53) and trimethylolpropane (54) are obtained via formaldehyde and acetaldehyde from syngas of the Biomass-to-Liquid (BtL) process or carbon monoxide hydrogenation. Moreover, according to their corresponding MSDS files, these polyols and ethyl-4-hydroxybenzoate show no toxic risk. Only the dibutyltin dilaurate (DBTDL), which is used as catalyst in the phenolation step and the unavoidable epichlorohydrin present safety risks.

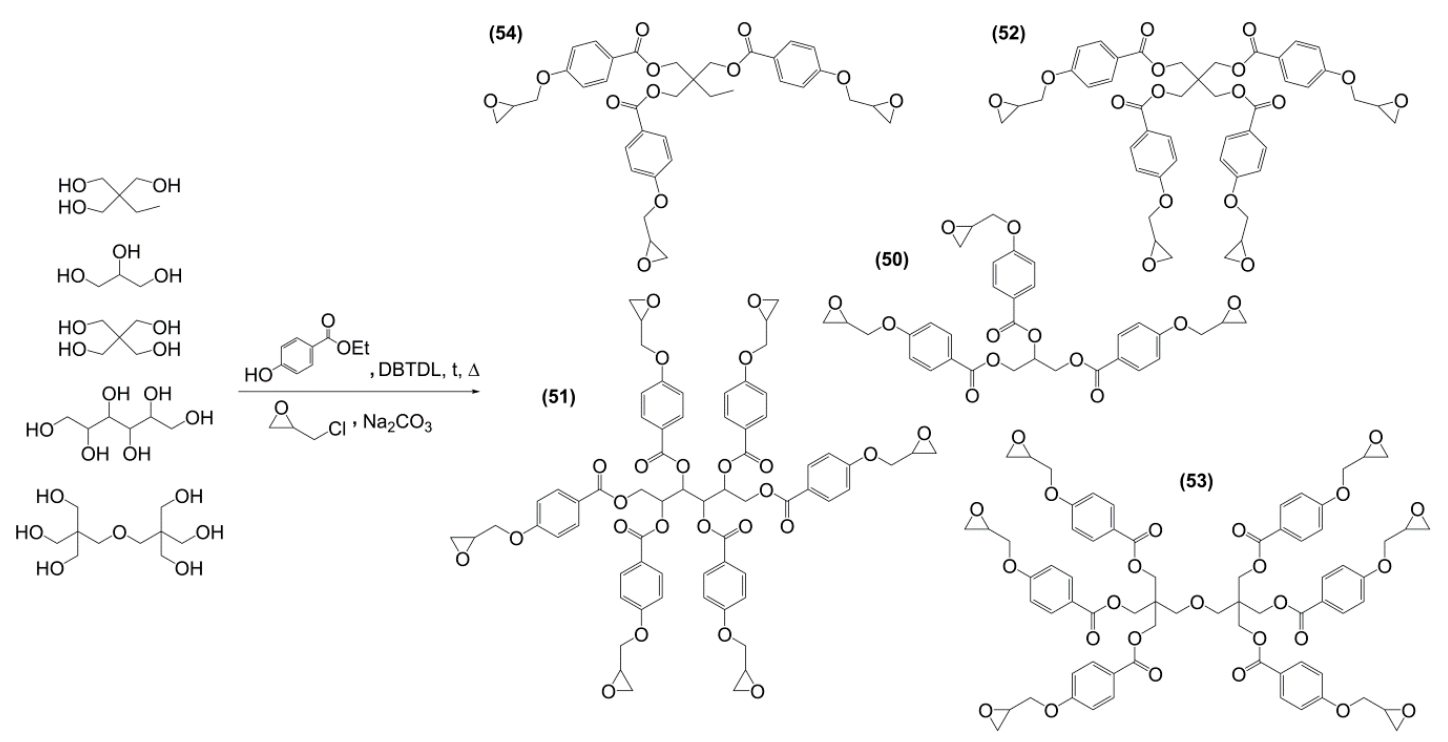

Scheme 14. Synthetic pathway to obtain poly-aromatic poly-glycidyl ethers developed by Fourcade et al. [167]. 
The phenolation step allowed $75 \%$ to $100 \%$ of conversion and the glycidylation of the resulting phenolic compounds led to an overall functionality ranging between 2 and 5 . The synthesized polyaromatic glycidyl epoxides were blended with DGEBA and cured with dicyandiamide. From a general point of view, the addition of these new resins decreased the glass transition temperature of the blend materials, up to $24 \%$ when $25 \%$ are used. Glycidyl ether of trimethylolpropane-tris (4-hydroxybenzoate) was cured with dicyandiamide in the absence of DGEBA and the corresponding material showed a $T_{\mathrm{g}}$ of $105^{\circ} \mathrm{C}$, slightly lower than that of DGEBA-based material $\left(119^{\circ} \mathrm{C}\right)$. This result is very promising since materials can be prepared from non-toxic hydroxyl compounds and almost meet the thermal properties of the harmful DGEBA-based materials.

Similarly, Ménard et al. [166] synthesized a tri-aromatic tri-epoxy monomer based on glycerol and ferulic acid (55) (Figure 30), although the esterification step was carried out with an enzymatic catalyst. After curing with IPDA, difurfurylamine and 1,10-diaminodecane, the thermosets showed $T_{\mathrm{g}}$ and $T_{\alpha}$ values ranging from 54 to $73^{\circ} \mathrm{C}$ and 67 to $92{ }^{\circ} \mathrm{C}$, respectively, with lowest values observed for the aliphatic diamine. These values remain significantly lower than those observed for DGEBA-based materials, as the increased functionality does not compensate the effect of the long aliphatic segments.

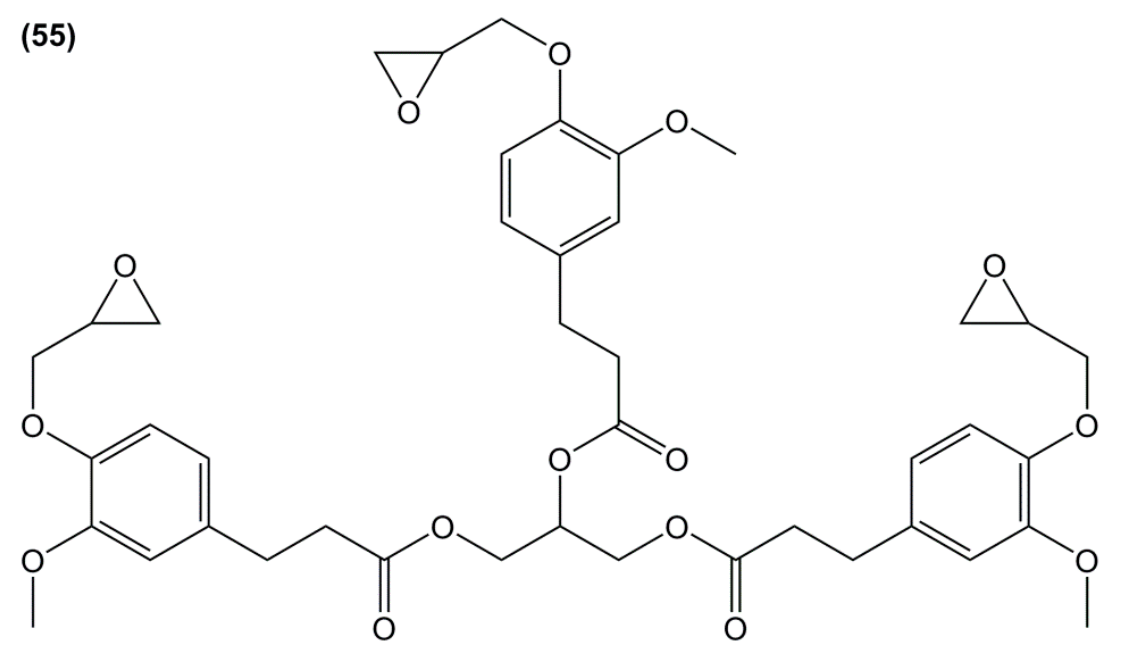

Figure 30. Tri-epoxy monomer based on ferulic acid and glycerol synthesized by Ménard et al. [166].

Very recently, Wan et al. [121,202] prepared two eugenol-based di-epoxy compounds, using a two-steps synthesis. The first step consisted in a Williamson etherification reaction between the hydroxyl group of eugenol and chloride aromatic derivatives, $\alpha, \alpha^{\prime}$-dichloro- $p$-xylene [202] or cyanuric chloride [121]. The resulting allylated intermediate was achieved with an almost quantitative yield. Then, the carbon-carbon double bonds were oxidized using $m$ CPBA with a moderate yield $(44 \%-70 \%)$, yielding di- (56) and tri-glycidylated (57) derivatives (Figure 31). Despite a high net bio-based content $(70 \%)$ of these new epoxy resins, the chosen synthetic pathway requires the use of $m$ CPBA, which is known to be dangerous, and chlorinated derivatives, which are highly toxic (H302-H314-H330) for cyaniric chloride and detrimental for the environment (H400) for $\alpha, \alpha^{\prime}$-dichloro- $p$-xylene.

Both eugenol-based epoxies showed lower reactivity towards amine than DGEBA, due to the lower electron withdrawing effect of the $-\mathrm{CH}_{2} \mathrm{Ph}$ epoxy-ring, compared to the usual $-\mathrm{CH}_{2} \mathrm{OPh}$ in BPA, but they avoid the use of epichlorohydrin and still, eugenol-based materials were successfully prepared by curing with aromatic diamines. The material based on the diglycidyl ether compounds prepared from $\alpha, \alpha^{\prime}$-dichloro- $p$-xylene showed a $T_{\mathrm{g}} 40{ }^{\circ} \mathrm{C}$ lower than for DGEBA-based materials, probably due to the methoxy groups on the aromatic rings and the $-\mathrm{CH}_{2} \mathrm{O}$ linkages between them. For the material obtained from cyanuric chloride, the glass transition temperature proved to be $33{ }^{\circ} \mathrm{C}$ higher despite the methoxy moieties, probably thanks to the tri-functional nature of the prepolymer. 
(56)

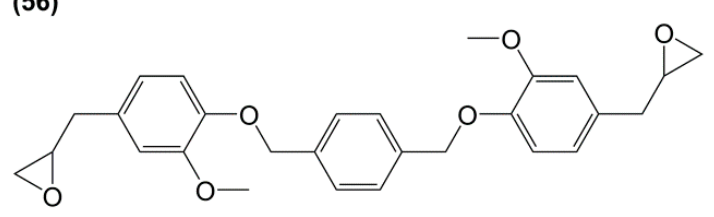

(58)

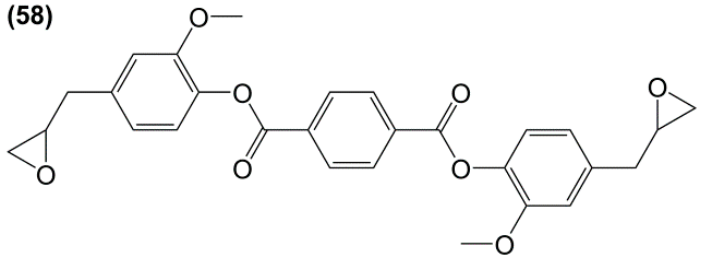<smiles>COc1cc(CC2CO2)ccc1Oc1nc(Oc2ccc(CC3CO3)cc2OC)nc(Oc2ccc(CC3CO3)cc2OC)n1</smiles>

Figure 31. Eugenol-based poly-aromatic epoxy monomers.

Wan et al. [120] also prepared a bio-based epoxy building block in a two-step synthesis from eugenol and terephthaloyl chloride: (i) a coupling reaction between eugenol and terephthaloyl chloride, followed by (ii) an epoxidation by oxidation of the $\mathrm{C}=\mathrm{C}$ double bonds (58). The coupling step allowed $93 \%$ of yield and the final product was a white solid. However, the high toxicity of the commercially available terephthaloyl chloride has to be taken in account. The material obtained by curing with 3,3'-diaminodiphenyl sulfone showed lower $T_{\mathrm{g}}$ and thermal stability and slightly higher mechanical properties than the one based on DGEBA. Furthermore, it exhibited interesting intrinsic flame retardancy.

Czub [203] considered recycling polyethylene terephthalate (PET) wastes, especially coming from bottles, for the synthesis of epoxy resins (59). The precursor of PET, terephtalic acid, is mostly produced by air oxidation of oil-based $p$-xylene [204]. However, as previously stated, $p$-xylene can be obtained from cellulosic biomass, for example via dehydration of iso-butanol into iso-butene, dimerization into iso-octene and catalytic conversion. It can also be synthesized by dehydrogenation of 3-carene extracted from pine tree or limonene extracted from citrus fruits into $p$-xylene. Thus, the author degraded PET waste by glycolysis reaction into small aromatic hydroxy telechelic oligomers. Using epichlorohydrin, these polyhydroxyl derivatives were glycidylated and mixed with DGEBA oligomers leading to an improved water absorption and resistance to $\mathrm{HNO}_{3}, \mathrm{H}_{2} \mathrm{SO}_{4}$ and ethyl acetate (Figure 32). The addition of 5\%-20\% of glycidylated PET-wastes in oligo(DGEBA) cured with isophorone diamine led to similar and slightly higher $T_{\mathrm{g}}$ values, from $56^{\circ} \mathrm{C}$ to $53-63^{\circ} \mathrm{C}$ measured in DMTA.<smiles>CC(C)(C)OCCOC(=O)c1ccc(C(=O)OCCOCC2CO2)cc1</smiles>

Figure 32. Epoxy monomers obtained from glycolyzed PET waste by Czub [203].

\subsubsection{Conclusions}

Due to their complexity and variability, bio-mass resources such as lignin or tannins have not received as much attention as smaller molecules for BPA substitution. However, as observed in the previous parts, they have been successfully turned into poly-epoxy monomers and used for the synthesis of materials exhibiting interesting properties. Similarly, smaller bio-based molecules such 
as eugenol and ferulic acid were turned into poly-aromatic epoxy monomers, but still few materials reached the high $T_{\mathrm{g}}$ values of their DGEBA counterparts. These results are gathered in Tables 6 and 7.

Table 6. Poly-aromatic epoxy monomers from crude bio-mass and thermal properties of the cured materials.

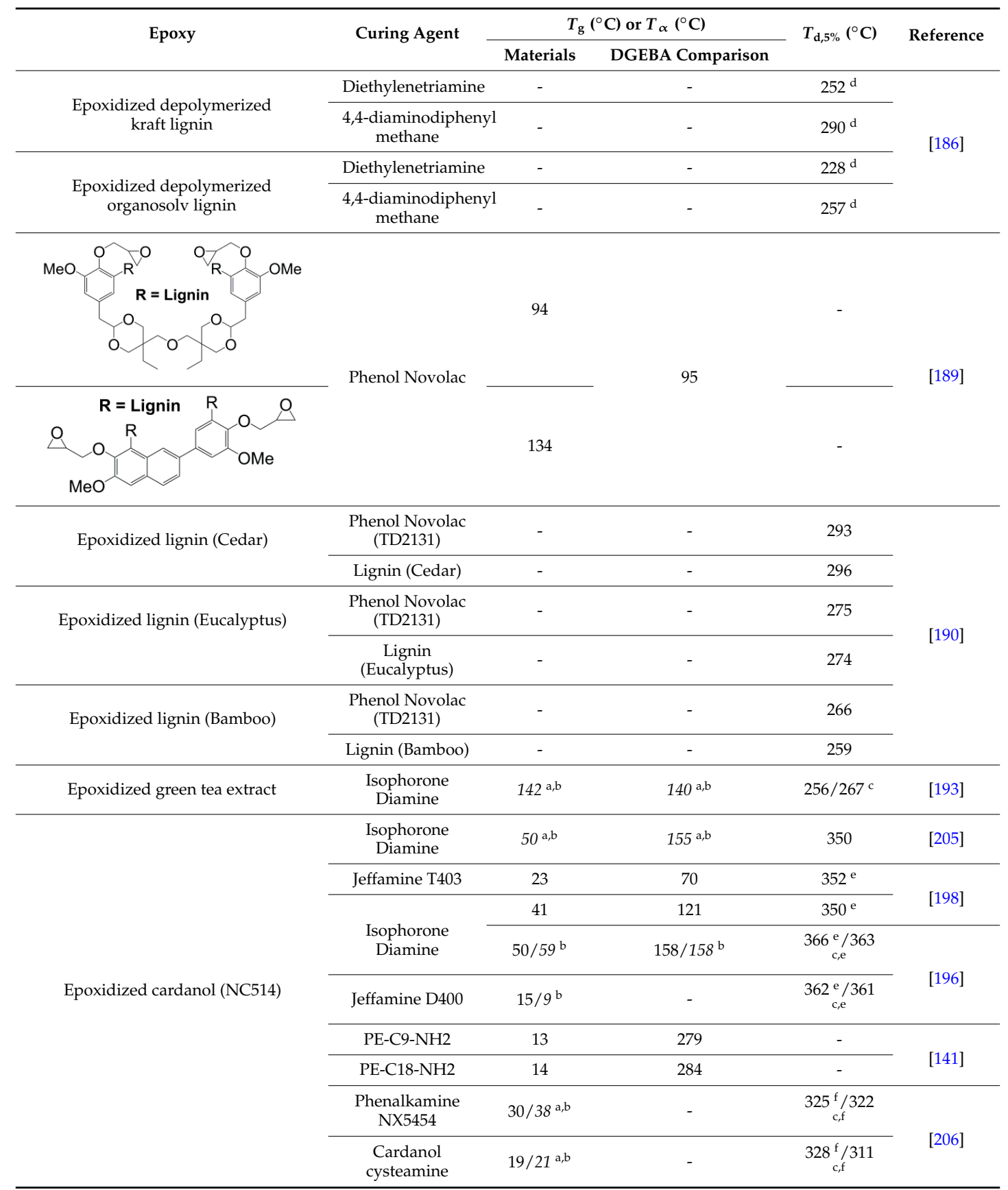

\footnotetext{
${ }^{a} T_{\alpha}$ measured by DMA at the peak position of loss modulus curve; ${ }^{\mathrm{b}} T_{\alpha}$ measured by DMA at the maximum of $\tan \delta ;{ }^{c} T_{\mathrm{d}}$ under air flow; ${ }^{\mathrm{d}}$ IDT = initial decomposition temperature; ${ }^{\mathrm{e}} T_{\mathrm{d}, 30 \%} ;{ }^{\mathrm{f}} T_{\mathrm{d}, 10 \%}$.
} 
Table 7. Poly-aromatic di- and tri-epoxy monomers and thermal properties of the cured materials.

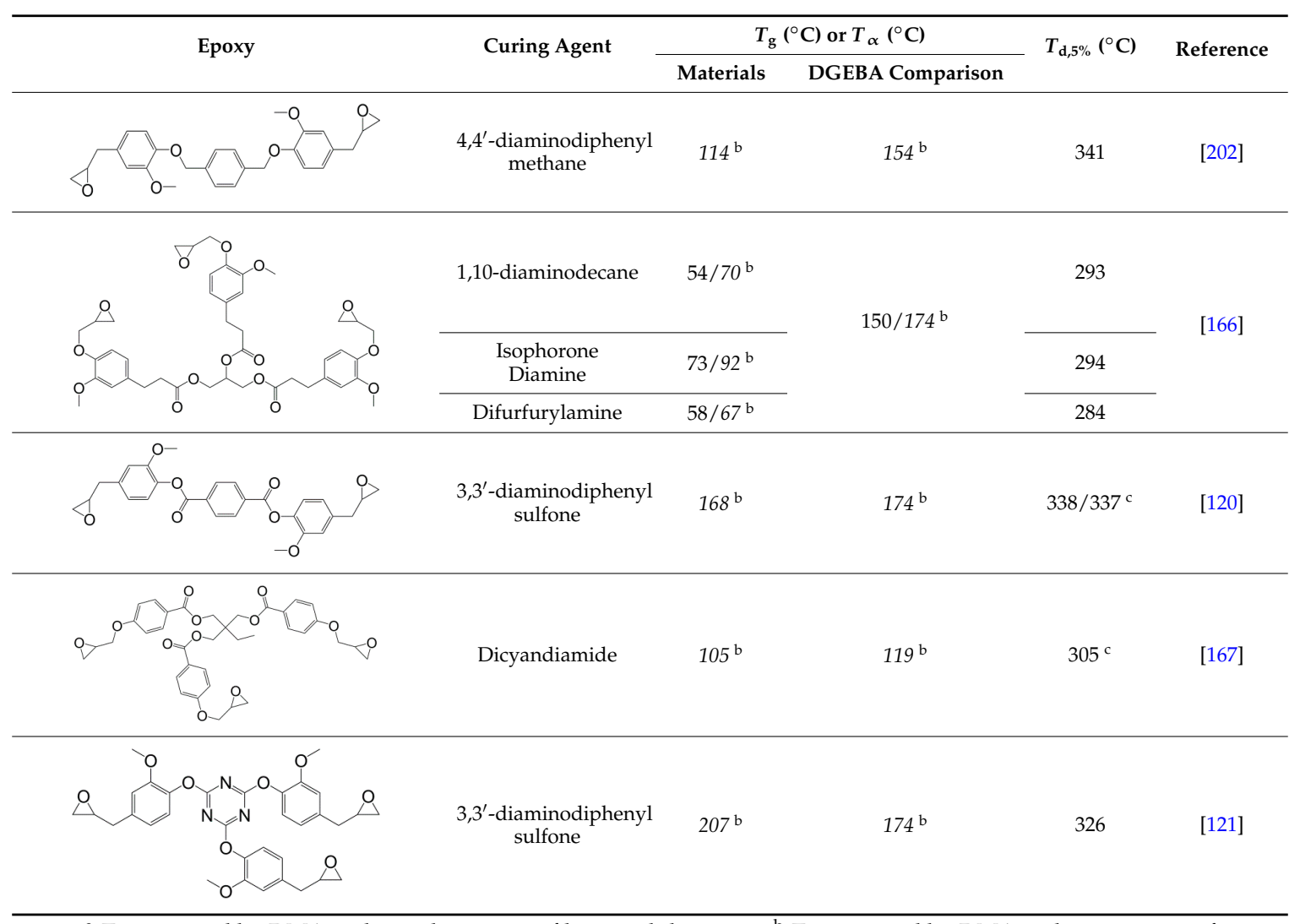

${ }^{\mathrm{a}} T_{\alpha}$ measured by DMA at the peak position of loss modulus curve; ${ }^{\mathrm{b}} T_{\alpha}$ measured by DMA at the maximum of $\tan \delta ;{ }^{\mathrm{c}} T_{\mathrm{d}}$ under air flow.

\section{General Conclusions}

Biorefinery processes and retreatment of biomass was out of our scope. However, it is clear that the future of bio-based polymers, including building blocks for thermosetting epoxies is strongly dependent on the future of biorefinery. The goal of a biorefinery is to produce high quality chemicals for fuels, monomers, and finally polymers and materials. New screening techniques like "Green Chemistry" and techno-economic and Life Cycle Assessment (LCA) indicators can help chemical-based biorefinery project developments. But efficient, economical, and large-scale synthesis of monomers is crucial, and the first key parameter remains a resource pool that should be abundant and easily accessed.

At first glance, there are a lot of opportunities to develop molecular biomass and monomers for preparation of renewable epoxy formulations and materials. But, the biggest changes for thermosetting epoxy formulations in the near future will certainly come from the regulation changes like the environmental directives for reducing Volatile Organic Constituents (VOC), the "Restriction of certain Hazardous Substances" (RoHS), or the "Registration, Evaluation and Authorisation of Chemicals", (REACh). Bio-based compounds will not be the only solution for these policy pressures but will be an opportunity.

There are many different routes to synthesize bio-based aromatic epoxy monomers and hence to replace DGEBA. However, we have to take into account several parameters such as the epoxy functionality; the different applications-for example coatings are totally different from composites and the adaptation of properties to applications. Hence, even if DGEBA is very interesting since it allows to cover all applications, it seems difficult to imagine to replace DGEBA by the same bio-based epoxy monomer in all applications. Currently, only a handful of patents led to commercialization of products, such as epoxided cardanol or vegetable oils. However, these epoxide monomers led to 
low $T_{\mathrm{g}}$ polyepoxide networks for low $T_{\mathrm{g}}$ applications. Epoxy aromatic monomers leading to high $T_{\mathrm{g}}$ polyepoxide are desired and correspond to an important challenge. Some industrial countries have declared bisphenol A (BPA) to be a toxic substance that causes risks to human health as well as to the environment; thus it has to be banned for all food contact applications in the next coming years, and in the immediate future the pressure is on its replacement. BPA is industrially produced from condensation of acetone with phenols. Therefore, bio-based aromatic/rigid epoxy monomers are still needed in order to fulfil good compromise between processing and properties, and able to enable replacement of BPA.

Developing highly efficient, safe, low waste, low toxicity and atom economy processes are the key words for green chemistry. Chemistry has to be simple, practical, and operational, and catalysts are expected to play an important role. Epichlorohydrin is the preferred way to prepare epoxy monomers; but epichlorohydrin is a toxic molecule which has to be manipulated in a safe environment. Epoxidation without the use of epichlorohydrin is a key challenge. Even if allylation or crotonization of alcohols can be a first step for epoxydation, the second step, i.e., double bond oxidation, requires the use of hazardous catalysts. Therefore, the oxidation of terminal double bonds is an interesting route but still needs research to propose industrial routes.

Conflicts of Interest: The authors declare no conflict of interest.

\section{References}

1. Auvergne, R.; Caillol, S.; David, G.; Boutevin, B.; Pascault, J.-P. Biobased Thermosetting Epoxy: Present and Future. Chem. Rev. 2014, 114, 1082-1115. [CrossRef] [PubMed]

2. Younes, M.; Wartewig, S.; Lellinger, D.; Strehmel, B.; Strehmel, V. The curing of epoxy resins as studied by various methods. Polymer 1994, 35, 5269-5278. [CrossRef]

3. Pascault, J.-P.; Williams, R.J.J. Epoxy Polymers: New Materials and Innovations; Wiley-VCH Verlag GmbH \& Co. KGaA: Weinheim, Germany, 2010; p. 367.

4. Araya-Hermosilla, R.; Fortunato, G.; Pucci, A.; Raffa, P.; Polgar, L.; Broekhuis, A.A.; Pourhossein, P.; Lima, G.M.R.; Beljaars, M.; Picchioni, F. Thermally reversible rubber-toughened thermoset networks via Diels-Alder chemistry. Eur. Polym. J. 2016, 74, 229-240. [CrossRef]

5. Giulivo, M.; de Lopez Alda, M.; Capri, E.; Barcelo, D. Human exposure to endocrine disrupting compounds: Their role in reproductive systems, metabolic syndrome and breast cancer: A review. Environ. Res. 2016, 151, 251-264. [CrossRef] [PubMed]

6. Brignon, J.-M.; Gouzy, A. Données Technico-Economiques sur les Substances Chimiques en France; Bisphénol A. INERIS: Paris, France, 2010; p. 77.

7. Vandenberg, L.N.; Hauser, R.; Marcus, M.; Olea, N.; Welshons, W.V. Human exposure to bisphenol A (BPA). Reprod. Toxicol. 2007, 24, 139-177. [CrossRef] [PubMed]

8. Calafat, A.M.; Kuklenyik, Z.; Reidy, J.A.; Caudill, S.P.; Ekong, J.; Needham, L.L. Urinary concentrations of bisphenol A and 4-nonylphenol in a human reference population. Environ. Health Perspect. 2005, 113, 391-395. [CrossRef] [PubMed]

9. Vom Saal, F.S.; Akingbemi, B.T.; Belcher, S.M.; Birnbaum, L.S.; Crain, D.A.; Eriksen, M.; Farabollini, F.; Guillette, L.J., Jr.; Hauser, R.; Heindel, J.J.; et al. Chapel Hill bisphenol A expert panel consensus statement: Integration of mechanisms, effects in animals and potential to impact human health at current levels of exposure. Reprod. Toxicol. 2007, 24, 131-138. [CrossRef] [PubMed]

10. Okada, H.; Tokunaga, T.; Liu, X.; Takayanagi, S.; Matsushima, A.; Shimohigashi, Y. Direct evidence revealing structural elements essential for the high binding ability of bisphenol A to human estrogen-related receptor- $\gamma$. Environ. Health Perspect. 2008, 116, 32-38. [CrossRef] [PubMed]

11. Commission Implementing Regulation (EU) $N^{\circ} 321 / 2011$ Amending Regulation (EU) $N^{\circ} 10 / 2011$ as regards the Restriction of Use of Bisphenol a in Plastic infant Feeding Bottles, Issued by European Commission, 01/04/2011. Available online: http:/ / eur-lex.europa.eu/homepage.html (accessed on 12 January 2017).

12. Commission Regulation (EU) $\mathrm{N}^{\circ} 10 / 2011$ on Plastic Materials and Articles Intended to Come into Contact with Food. Available online: http://eur-lex.europa.eu/homepage.html (accessed on 12 January 2017). 
13. Biermann, U.; Friedt, W.; Lang, S.; Luhs, W.; Machmuller, G.; Metzger, J.O.; Klaas, M.R.; Schafer, H.J.; Schneider, M.P. New syntheses with oils and fats as renewable raw materials for the chemical industry. Angew. Chem. Int. Ed. 2000, 39, 2206-2224. [CrossRef]

14. Zahradnik, L.; Tynova, E.; Kalouskova, H. Stable epoxy resins made from renewable nontraditional resources-Economically and environmentally acceptable solution. Koroze Ochr. Mater. 2005, 49, 83-86.

15. Meier, M.A.R.; Metzger, J.O.; Schubert, U.S. Plant oil renewable resources as green alternatives in polymer science. Chem. Soc. Rev. 2007, 36, 1788-1802. [CrossRef] [PubMed]

16. Voirin, C.; Caillol, S.; Sadavarte, N.V.; Tawade, B.V.; Boutevin, B.; Wadgaonkar, P.P. Functionalization of cardanol: Towards biobased polymers and additives. Polym. Chem. 2014, 5, 3142-3162. [CrossRef]

17. Hernandez, E.D.; Bassett, A.W.; Sadler, J.M.; La Scala, J.J.; Stanzione, J.F. Synthesis and Characterization of Bio-based Epoxy Resins Derived from Vanillyl Alcohol. ACS Sustain. Chem. Eng. 2016, 4, 4328-4339. [CrossRef]

18. Baroncini, E.A.; Kumar Yadav, S.; Palmese, G.R.; Stanzione, J.F., III. Recent advances in bio-based epoxy resins and bio-based epoxy curing agents. J. Appl. Polym. Sci. 2016, 133. [CrossRef]

19. Ma, S.; Li, T.; Liu, X.; Zhu, J. Research progress on bio-based thermosetting resins. Polym. Int. 2016, 65, 164-173. [CrossRef]

20. Ding, C.; Matharu, A.S. Recent Developments on Biobased Curing Agents: A Review of Their Preparation and Use. ACS Sustain. Chem. Eng. 2014, 2, 2217-2236. [CrossRef]

21. Shibata, M. Biocomposites Composed of Bio-Based Epoxy Resins, Bio-Based Polyphenols and Lignocellulosic Fibers; Thakur, V.K., Kessler, M.R., Eds.; Apple Academic Press Inc.: Oakville, ON, Canada, 2015; pp. 111-160.

22. Aouf, C.; Nouailhas, H.; Fache, M.; Caillol, S.; Boutevin, B.; Fulcrand, H. Multi-functionalization of gallic acid. Synthesis of a novel bio-based epoxy resin. Eur. Polym. J. 2013, 49, 1185-1195. [CrossRef]

23. Pham, H.Q.; Marks, M.J. Epoxy resins. In Ullmann's Encyclopedia of Industrial Chemistry; John Wiley \& Sons, Inc.: Hoboken, NJ, USA, 2005.

24. Guizzunti, G.; Brady, T.P.; Malhotra, V.; Theodorakis, E.A. Chemical Analysis of Norrisolide-Induced Golgi Vesiculation. J. Am. Chem. Soc. 2006, 128, 4190-4191. [CrossRef] [PubMed]

25. Beasley, Y.M.; Petrow, V.; Stephenson, O. Analgesics. I. Aryloxypropanolamines. J. Pharm. Pharmacol. 1958, 10, 47-59. [CrossRef] [PubMed]

26. Bradley, W.; Forrest, J.; Stephenson, O. Catalyzed transfer of hydrogen chloride from chlorohydrins to epoxides. A new method of preparing glycidol and some of its derivatives. J. Chem. Soc. 1951, 1589-1598. [CrossRef]

27. Fache, M.; Darroman, E.; Besse, V.; Auvergne, R.; Caillol, S.; Boutevin, B. Vanillin, a promising biobased building-block for monomer synthesis. Green Chem. 2014, 16, 1987-1998. [CrossRef]

28. Jovanovic, S.; Vico-Stevanovic, M.; Ugljesic-Kilibarda, D.; Popadic, D.; Simic, S.; Dzeletovic, D. Catalysis in the alkylation reaction of 1-naphthol with epichlorohydrin. J. Serb. Chem. Soc. 2006, 71, 867-877. [CrossRef]

29. Jovanovic, S.S.; Misic-Vukovic, M.M.; Djokovic, D.D.; Bajic, D.S. Phase-transfer catalysis in the alkylation reaction of $\alpha$-naphthol with epichlorohydrin. J. Mol. Catal. 1992, 73, 9-16. [CrossRef]

30. Poustka, J.; Dunovska, L.; Hajslova, J.; Holadova, K.; Poustkova, I. Determination and occurrence of bisphenol A, bisphenol A diglycidyl ether, and bisphenol $\mathrm{F}$ diglycidyl ether, including their derivatives, in canned foodstuffs' from the Czech retail market. Czech J. Food Sci. 2007, 25, 221-229.

31. Pchelka, B.K.; Loupy, A.; Petit, A. Improvement and simplification of synthesis of 3-aryloxy-1,2epoxypropanes using solvent-free conditions and microwave irradiations. Relation with medium effects and reaction mechanism. Tetrahedron 2006, 62, 10968-10979. [CrossRef]

32. Stephenson, O. The condensation of epichlorohydrin with monohydric phenols and with catechol. J. Chem. Soc. 1954, 1571-1577. [CrossRef]

33. Bukowska, A.; Bukowski, W.; Mossety-Leszczak, B. Synthesis of glycidyl esters. J. Chem. Technol. Biotechnol. 1999, 74, 1145-1148. [CrossRef]

34. Erickson, J.G. Method of Preparing Glycidyl Ester. U.S. 2567842, 11 September 1951.

35. Iwakura, Y.; Kurosaki, T.; Oishi, H.; Goto, K. Glycidyl Esters. JP38024363B4, 15 November 1963.

36. Mueller, A.C. Process for Preparing Epoxy Esters. U.S. 2772296, 27 November 1956.

37. Tanaka, Y.; Kakiuchi, H. Glycidyl Esters of Aromatic Acids. J. Macromol. Sci. Part A Pure Appl. Chem. 1967, 1, 1469-1485. [CrossRef] 
38. Aouf, C.; le Guerneve, C.; Caillol, S.; Fulcrand, H. Study of the O-glycidylation of natural phenolic compounds. The relationship between the phenolic structure and the reaction mechanism. Tetrahedron 2013, 69, 1345-1353. [CrossRef]

39. Meurs, J.H.H.; Smits, J.J.T.; Walhof, J.J.B. Process for the Manufacture of Epoxy Compounds. WO9909020A1, 25 February 1999.

40. Aouf, C.; Lecomte, J.; Villeneuve, P.; Dubreucq, E.; Fulcrand, H. Chemo-enzymatic functionalization of gallic and vanillic acids: Synthesis of bio-based epoxy resins prepolymers. Green Chem. 2012, 14, 2328-2336. [CrossRef]

41. Wang, Z.-X.; Tu, Y.; Frohn, M.; Zhang, J.-R.; Shi, Y. An Efficient Catalytic Asymmetric Epoxidation Method. J. Am. Chem. Soc. 1997, 119, 11224-11235. [CrossRef]

42. Curci, R.; Fiorentino, M.; Troisi, L.; Edwards, J.O.; Pater, R.H. Epoxidation of alkenes by dioxirane intermediates generated in the reaction of potassium caroate with ketones. J. Org. Chem. 1980, 45, 4758-4760. [CrossRef]

43. Adam, W.; Hadjiarapoglou, L.; Jaeger, V.; Klicic, J.; Seidel, B.; Wang, X. Epoxidation of enol silyl ethers, phosphates, esters, and lactones by dimethyldioxirane. Chem. Ber. 1991, 124, 2361-2368. [CrossRef]

44. Kurihara, M.; Ito, S.; Tsutsumi, N.; Miyata, N. Stereoselective epoxidation with dioxiranes generated from ketones. Tetrahedron Lett. 1994, 35, 1577-1580. [CrossRef]

45. Yang, D.; Wong, M.-K.; Yip, Y.-C. Epoxidation of Olefins Using Methyl(trifluoromethyl)dioxirane Generated in Situ. J. Org. Chem. 1995, 60, 3887-3889. [CrossRef]

46. Tiran, C.; Lecomte, J.; Dubreucq, E.; Villeneuve, P. Chemo-enzymatic epoxidation of fatty compounds-Focus on processes involving a lipase-catalyzed perhydrolysis step. Oilseed Corps Gras Lipides 2008, 15, 179-183. [CrossRef]

47. Fache, M.; Viola, A.; Auvergne, R.; Boutevin, B.; Caillol, S. Biobased epoxy thermosets from vanillin-derived oligomers. Eur. Polym. J. 2015, 68, 526-535. [CrossRef]

48. Grunchard, F. Process for the Manufacture of Epichlorohydrin. EP561441A1, 22 September 1993.

49. Balthasart, D.; Gilbeau, P.; Krafft, P. Process for Manufacturing Epichlorohydrin. WO2012056005A1, 3 May 2012.

50. Gilbeau, P.; Krafft, P. Manufacture of Epichlorohydrin from Dichloropropanol. WO2008101866A2, 28 August 2008.

51. Krafft, P.; Gilbeau, P. Manufacture of Dichloropropanol from Glycerol Containing Small Amounts of Glycols. WO2009000773A1, 31 December 2008.

52. Krafft, P.; Gilbeau, P. Glycerol-Based Products, Process for Its Purification, and Its Use in Preparation of Dichloropropanol. FR2918058A1, 2 January 2007.

53. Krafft, P.; Gilbeau, P.; Balthasart, D. Manufacture and Use of Epichlorohydrin with Low Concentration of Halohydrocarbons. FR2917411A1, 19 December 2008.

54. "Effets sanitaires du bisphénol $A$ " and "Connaissances Relatives aux Usages du Bisphenol A"; Collective Report; ANSES: Paris, France, 2011; p. 383.

55. Geens, T.; Aerts, D.; Berthot, C.; Bourguignon, J.-P.; Goeyens, L.; Lecomte, P.; Maghuin-Rogister, G.; Pironnet, A.-M.; Pussemier, L.; Scippo, M.-L.; et al. A review of dietary and non-dietary exposure to bisphenol-A. Food Chem. Toxicol. 2012, 50, 3725-3740. [CrossRef] [PubMed]

56. Calafat, A.M.; Weuve, J.; Ye, X.; Jia, L.T.; Hu, H.; Ringer, S.; Huttner, K.; Hauser, R. Exposure to bisphenol A and other phenols in neonatal intensive care unit premature infants. Environ. Health Perspect. 2009, 117, 639-644. [CrossRef] [PubMed]

57. Stanton, K.; Kruszewski, F.H. Quantifying the benefits of using read-across and in silico techniques to fulfill hazard data requirements for chemical categories. Regul. Toxicol. Pharmacol. 2016, 81, 250-259. [CrossRef] [PubMed]

58. Coleman, K.P.; Toscano, W.A., Jr.; Wiese, T.E. QSAR models of the in vitro estrogen activity of bisphenol A analogs. QSAR Comb. Sci. 2003, 22, 78-88. [CrossRef]

59. Delfosse, V.; Grimaldi, M.; Pons, J.-L.; Boulahtouf, A.; Le Maire, A.; Cavailles, V.; Labesse, G.; Bourguet, W.; Balaguer, P. Structural and mechanistic insights into bisphenols action provide guidelines for risk assessment and discovery of bisphenol A substitutes. Proc. Natl. Acad. Sci. USA. 2012, 109, 14930-14935. [CrossRef] [PubMed] 
60. Dolinoy, D.C.; Huang, D.; Jirtle, R.L. Maternal nutrient supplementation counteracts bisphenol A-induced DNA hypomethylation in early development. Proc. Natl. Acad. Sci. USA 2007, 104, 13056-13061. [CrossRef] [PubMed]

61. Dodds, E.C.; Lawson, W. Molecular structure in relation to estrogenic activity: Compounds without a phenanthrene nucleus. Proc. R. Soc. Lond. Ser. B 1938, 125, 222-232. [CrossRef]

62. Krishnan, A.V.; Stathis, P.; Permuth, S.F.; Tokes, L.; Feldman, D. Bisphenol-A: An estrogenic substance is released from polycarbonate flasks during autoclaving. Endocrinology (Baltimore) 1993, 132, 2279-2286.

63. Kuiper, G.G.J.M.; Lemmen, J.G.; Carlsson, B.; Corton, J.C.; Safe, S.H.; Van Der Saag, P.T.; van der Burg, B.; Gustafsson, J.-A. Interaction of estrogenic chemicals and phytoestrogens with estrogen receptor $\beta$. Endocrinology 1998, 139, 4252-4263. [PubMed]

64. Olea, N.; Pulgar, R.; Perez, P.; Olea-Serrano, F.; Rivas, A.; Novillo-Fertrell, A.; Pedraza, V.; Soto, A.M.; Sonnenschein, C. Estrogenicity of resin-based composites and sealants used in dentistry. Environ. Health Perspect. 1996, 104, 298-305. [CrossRef] [PubMed]

65. Takayanagi, S.; Tokunaga, T.; Liu, X.; Okada, H.; Matsushima, A.; Shimohigashi, Y. Endocrine disruptor bisphenol A strongly binds to human estrogen-related receptor $\gamma(E R R \gamma)$ with high constitutive activity. Toxicol. Lett. 2006, 167, 95-105. [CrossRef] [PubMed]

66. Sohoni, P.; Sumpter, J.P. Several environmental estrogens are also anti-androgens. J. Endocrinol. 1998, 158, 327-339. [CrossRef] [PubMed]

67. Xu, L.-C.; Sun, H.; Chen, J.-F.; Bian, Q.; Qian, J.; Song, L.; Wang, X.-R. Evaluation of androgen receptor transcriptional activities of bisphenol A, octylphenol and nonylphenol in vitro. Toxicology 2005, 216, 197-203. [CrossRef] [PubMed]

68. Vandenberg, L.N.; Ehrlich, S.; Belcher, S.M.; Ben-Jonathan, N.; Dolinoy, D.C.; Hugo, E.R.; Hunt, P.A.; Newbold, R.R.; Rubin, B.S.; Saili, K.S.; et al. Low dose effects of bisphenol A. Endocr. Disrupt. 2013, 1, e26490. [CrossRef]

69. Agatonovic-Kustrin, S.; Turner, J.V. Molecular structural characteristics of estrogen receptor modulators as determinants of estrogen receptor selectivity. Mini-Rev. Med. Chem. 2008, 8, 943-951. [CrossRef] [PubMed]

70. Hu, J.-Y.; Aizawa, T. Quantitative structure-activity relationships for estrogen receptor binding affinity of phenolic chemicals. Water Res. 2003, 37, 1213-1222. [CrossRef]

71. Anstead, G.M.; Carlson, K.E.; Katzenellenbogen, J.A. The estradiol pharmacophore: Ligand structure-estrogen receptor binding affinity relationships and a model for the receptor binding site. Steroids 1997, 62, 268-303. [CrossRef]

72. Fang, H.; Tong, W.; Shi, L.M.; Blair, R.; Perkins, R.; Branham, W.; Hass, B.S.; Xie, Q.; Dial, S.L.; Moland, C.L.; et al. Structure-Activity Relationships for a Large Diverse Set of Natural, Synthetic, and Environmental Estrogens. Chem. Res. Toxicol. 2001, 14, 280-294. [CrossRef] [PubMed]

73. Perez, P.; Pulgar, R.; Olea-Serrano, F.; Villalobos, M.; Rivas, A.; Metzler, M.; Pedraza, V.; Olea, N. The estrogenicity of bisphenol A-related diphenylalkanes with various substituents at the central carbon and the hydroxy groups. Environ. Health Perspect. 1998, 106, 167-174. [CrossRef] [PubMed]

74. Brzozowski, A.M.; Pike, A.C.W.; Dauter, Z.; Hubbard, R.E.; Bonn, T.; Engstrom, O.; Ohman, L.; Greene, G.L.; Gustafsson, J.-A.; Carlquist, M. Molecular basis of agonism and antagonism in the estrogen receptor. Nature 1997, 389, 753-758. [CrossRef] [PubMed]

75. Tanenbaum, D.M.; Wang, Y.; Williams, S.P.; Sigler, P.B. Crystallographic comparison of the estrogen and progesterone receptor's ligand binding domains. Proc. Natl. Acad. Sci. USA 1998, 95, 5998-6003. [CrossRef] [PubMed]

76. "Reproduction et Environnement", Chapter V Bisphénol A, Part 30 Relation Structure-Fonction; Collective Report; INSERM: Paris, France, 2011; pp. 319-326.

77. Liu, H.; Papa, E.; Walker, J.D.; Gramatica, P. In silico screening of estrogen-like chemicals based on different nonlinear classification models. J. Mol. Gr. Modell. 2007, 26, 135-144. [CrossRef] [PubMed]

78. Directive 94/33/EC on the Protection of Young People at Work, Issued by Council of the European Union, 22/06/1994. Available online: http:/ / eur-lex.europa.eu/homepage.html (accessed on 12 January 2017).

79. Directive 2009/48/EC on the Safety of Toys, Annex II.III.3, Issued by the European Parliament and the Council of the European Union, 18/06/2009. Available online: http://eur-lex.europa.eu/homepage.html (accessed on 12 January 2017). 
80. Commission Directive 2014/81/EU Amending Appendix C of Annex II to Directive 2009/48/EC of the European Parliament and of the Council on the Safety of Toys, as Regards Bisphenol A, Issued by European Commission, 23/06/2014. Available online: http://eur-lex.europa.eu/homepage.html (accessed on 12 January 2017).

81. Regulation (EC) $\mathrm{N}^{\circ} 1223 / 2009$ of the European Parliament and of the Council, Issued by The European Parliament and the Council of the European Union, 30/11/2009. Available online: http:/ / eur-lex.europa. eu/homepage.html (accessed on 12 January 2017).

82. Regulation (EC) $N^{\circ} 1980 / 2000$ of the European Parliament and of the Council on a Revised Community Eco-Label Award Scheme, Issued by The European Parliament and the Council of the European Union, 17/07/2000. Available online: http:/ / eur-lex.europa.eu/homepage.html (accessed on 12 January 2017).

83. Commission Directive 2009/161/EU Establishing a Third List of Indicative Occupational Exposure limit Values in Implementation of Council Directive 98/24/EC and Amending Commission Directive 2000/39/EC, 17/12/2009. Available online: http:/ / eur-lex.europa.eu/homepage.html (accessed on 12 January 2017).

84. Law N $\mathrm{N}^{\circ}$ 2010-729 "Tendant à Suspendre la Commercialisation de Tout Conditionnement Comportant du Bisphénol A et Destiné à Recevoir des Produits Alimentaires" NOR: SASX1008554L, 30/06/2010 Consolidated 20/10/2016. Available online: https://www.legifrance.gouv.fr/affichTexte.do?cidTexte= JORFTEXT000022414734 (accessed on 12 January 2017).

85. Current Substances of Very High Concern Intentions: 4,4'-Isopropylidenediphenol (Bisphenol A; BPA), Issued by European Chemicals Agency, 08/02/2016. Available online: https:/ /echa.europa.eu/registry-ofcurrent-svhc-intentions (accessed on 12 January 2017).

86. Rochester, J.R. Bisphenol A and human health: A review of the literature. Reprod. Toxicol. 2013, 42, 132-155. [CrossRef] [PubMed]

87. Usman, A.; Ahmad, M. From BPA to its analogues: Is it a safe journey? Chemosphere 2016, 158, 131-142. [CrossRef] [PubMed]

88. Chen, D.; Kannan, K.; Tan, H.; Zheng, Z.; Feng, Y.-L.; Wu, Y.; Widelka, M. Bisphenol Analogues Other Than BPA: Environmental Occurrence, Human Exposure, and Toxicity-A Review. Environ. Sci. Technol. 2016, 50, 5438-5453. [CrossRef] [PubMed]

89. Rochester, J.R.; Bolden, A.L. Bisphenol S and F: A Systematic Review and Comparison of the Hormonal Activity of Bisphenol A Substitutes. Environ Health Perspect. 2015, 123, 643-650. [CrossRef] [PubMed]

90. Gandini, A. The irruption of polymers from renewable resources on the scene of macromolecular science and technology. Green Chem. 2011, 13, 1061-1083. [CrossRef]

91. Lochab, B.; Shukla, S.; Varma, I.K. Naturally occurring phenolic sources: Monomers and polymers. RSC Adv. 2014, 4, 21712-21752. [CrossRef]

92. Belgacem, M.N.; Gandini, A. Monomers, Polymers and Composites from Renewable Resources; Elsevier Ltd.: Amsterdam, The Netherlands, 2008; p. 552.

93. Laurichesse, S.; Averous, L. Chemical modification of lignins: Towards biobased polymers. Prog. Polym. Sci. 2014, 39, 1266-1290. [CrossRef]

94. Key, R.E.; Bozell, J.J. Progress toward Lignin Valorization via Selective Catalytic Technologies and the Tailoring of Biosynthetic Pathways. ACS Sustain. Chem. Eng. 2016. Ahead of Print. [CrossRef]

95. Illy, N.; Fache, M.; Ménard, R.; Negrell, C.; Caillol, S.; David, G. Phosphorylation of bio-based compounds: The state of the art. Polym. Chem. 2015, 6, 6257-6291. [CrossRef]

96. Duval, A.; Lange, H.; Lawoko, M.; Crestini, C. Reversible crosslinking of lignin via the furan-maleimide Diels-Alder reaction. Green Chem. 2015, 17, 4991-5000. [CrossRef]

97. Oliveira, F.D.; Ramires, E.C.; Frollini, E.; Belgacem, M.N. Lignopolyurethanic materials based on oxypropylated sodium lignosulfonate and castor oil blends. Ind. Crops Prod. 2015, 72, 77-86. [CrossRef]

98. Arbenz, A.; Averous, L. Chemical modification of tannins to elaborate aromatic biobased macromolecular architectures. Green Chem. 2015, 17, 2626-2646. [CrossRef]

99. Bacelo, H.A.M.; Santos, S.C.R.; Botelho, C.M.S. Tannin-based biosorbents for environmental applications-A review. Chem. Eng. J. 2016, 303, 575-587. [CrossRef]

100. Eghbaliferiz, S.; Iranshahi, M. Prooxidant Activity of Polyphenols, Flavonoids, Anthocyanins and Carotenoids: Updated Review of Mechanisms and Catalyzing Metals. Phytother. Res. 2016, 30, 1379-1391. [CrossRef] [PubMed] 
101. Ekambaram, S.P.; Perumal, S.S.; Balakrishnan, A. Scope of Hydrolysable Tannins as Possible Antimicrobial Agent. Phytother. Res. 2016, 30, 1035-1045. [CrossRef] [PubMed]

102. Roumeas, L.; Aouf, C.; Dubreucq, E.; Fulcrand, H. Depolymerization of condensed tannins in ethanol as a gateway to biosourced phenolic synthons. Green Chem. 2013, 15, 3268-3275. [CrossRef]

103. Roumeas, L.; Fulcrand, H.; Aouf, C.; Dubreucq, E. Preparation of Flavanoid Derivatives by Depolymerization of Condensed Tannins. WO2016020615A1, 11 February 2016.

104. Mubofu, E.B. From cashew nut shell wastes to high value chemicals. Pure Appl. Chem. 2016, 88, 17-27. [CrossRef]

105. Chen, J.; Liu, Z.; Jiang, J.; Nie, X.; Zhou, Y.; Murray, R.E. A novel biobased plasticizer of epoxidized cardanol glycidyl ether: Synthesis and application in soft poly(vinyl chloride) films. RSC Adv. 2015, 5, 56171-56180. [CrossRef]

106. Liu, Z.; Chen, J.; Knothe, G.; Nie, X.; Jiang, J. Synthesis of Epoxidized Cardanol and Its Antioxidative Properties for Vegetable Oils and Biodiesel. ACS Sustain. Chem. Eng. 2016, 4, 901-906. [CrossRef]

107. Patel, M.B.; Patel, R.D.; Patel, R.G.; Patel, V.S. Glass-fibre-reinforced Epoxy Composites using Epoxidized Cardanol as Diluent. High Perform. Polym. 1991, 3, 107-111. [CrossRef]

108. Zhu, H.; Luo, W.; Ciesielski, P.N.; Fang, Z.; Zhu, J.Y.; Henriksson, G.; Himmel, M.E.; Hu, L. Wood-Derived Materials for Green Electronics, Biological Devices, and Energy Applications. Chem. Rev. 2016, 116, 9305-9374. [CrossRef] [PubMed]

109. Deng, W.; Zhang, Q.; Wang, Y. Catalytic transformations of cellulose and its derived carbohydrates into 5-hydroxymethylfurfural, levulinic acid, and lactic acid. Sci. China Chem. 2015, 58, 29-46. [CrossRef]

110. Hayes, D.J.; Fitzpatrick, S.; Hayes, M.H.B.; Ross, J.R.H. The Biofine Process-Production of Levulinic acid, Furfural, and Formic acid from Lignocellulosic Feedstocks; Wiley-VCH Verlag GmbH \& Co. KGaA: Weinheim, Germany, 2006; pp. 139-164.

111. Gibson, L.J. The hierarchical structure and mechanics of plant materials. J. R. Soc. Interface 2012, 9, $2749-2766$. [CrossRef] [PubMed]

112. Cho, J.G.; Kim, B.J.; Kim, S.Y.; Lee, D.H.; Lee, S.H.; Lee, J.S. Preparation of Furan-Based Curable Compounds Derived from Biomass for Solvent-Free Curable Compositions. KR1116450B1, 30 August 2012.

113. Cho, J.K.; Lee, J.-S.; Jeong, J.; Kim, B.; Kim, B.; Kim, S.; Shin, S.; Kim, H.-J.; Lee, S.-H. Synthesis of carbohydrate biomass-based furanic compounds bearing epoxide end group(s) and evaluation of their feasibility as adhesives. J. Adhes. Sci. Technol. 2013, 27, 2127-2138. [CrossRef]

114. Cho, J.-K.; Kim, S.-Y.; Lee, D.-H.; Kim, B.-R.; Kim, B.-J.; Jung, J.-W.; Lee, S.-H.; Lee, J.-S. Preparation of Furan-Based Curable Compounds Derived from Biomass for Solvent-Free Curable Compositions. WO2011030991A1, 17 March 2011.

115. Wool, R.; Sun, X.S. Bio-Based Polymers and Composites; Academic Press: Cambridge, MA, USA, 2011 ; p. 641.

116. Garrison, M.D.; Harvey, B.G. Bio-based hydrophobic epoxy-amine networks derived from renewable terpenoids. J. Appl. Polym. Sci. 2016, 133. [CrossRef]

117. Harvey, B.G.; Guenthner, A.J.; Koontz, T.A.; Storch, P.J.; Reams, J.T.; Groshens, T.J. Sustainable hydrophobic thermosetting resins and polycarbonates from turpentine. Green Chem. 2016, 18, 2416-2423. [CrossRef]

118. Llevot, A.; Dannecker, P.-K.; von Czapiewski, M.; Over, L.C.; Soyler, Z.; Meier, M.A.R. Renewability is not Enough: Recent Advances in the Sustainable Synthesis of Biomass-Derived Monomers and Polymers. Chemistry 2016, 22, 11510-11521. [CrossRef] [PubMed]

119. Qin, J.; Liu, H.; Zhang, P.; Wolcott, M.; Zhang, J. Use of eugenol and rosin as feedstocks for biobased epoxy resins and study of curing and performance properties. Polym. Int. 2014, 63, 760-765. [CrossRef]

120. Wan, J.; Gan, B.; Li, C.; Molina-Aldareguia, J.; Li, Z.; Wang, X.; Wang, D.-Y. A novel biobased epoxy resin with high mechanical stiffness and low flammability: Synthesis, characterization and properties. J. Mater. Chem. A 2015, 3, 21907-21921. [CrossRef]

121. Wan, J.; Zhao, J.; Gan, B.; Li, C.; Molina-Aldareguia, J.; Zhao, Y.; Pan, Y.-T.; Wang, D.-Y. Ultrastiff Biobased Epoxy Resin with High $T_{\mathrm{g}}$ and Low Permittivity: From Synthesis to Properties. ACS Sustain. Chem. Eng. 2016, 4, 2869-2880. [CrossRef]

122. Raja, M.R.C.; Srinivasan, V.; Selvaraj, S.; Mahapatra, S.K. Eugenol: A versatile phytomedicine. Int. J. Pharm. Pharm. Sci. 2015, 7, 35-40.

123. Maiorana, A.; Reano, A.F.; Centore, R.; Grimaldi, M.; Balaguer, P.; Allais, F.; Gross, R.A. Structure property relationships of biobased n-alkyl bisferulate epoxy resins. Green Chem. 2016, 18, 4961-4973. [CrossRef] 
124. Oulame, M.Z.; Pion, F.; Allauddin, S.; Raju, K.V.S.N.; Ducrot, P.-H.; Allais, F. Renewable alternating aliphatic-aromatic poly(ester-urethane)s prepared from ferulic acid and bio-based diols. Eur. Polym. J. 2015, 63, 186-193. [CrossRef]

125. Pion, F.; Ducrot, P.-H.; Allais, F. Renewable Alternating Aliphatic-Aromatic Copolyesters Derived from Biobased Ferulic Acid, Diols, and Diacids: Sustainable Polymers with Tunable Thermal Properties. Macromol. Chem. Phys. 2014, 215, 431-439. [CrossRef]

126. Pion, F.; Reano, A.F.; Ducrot, P.-H.; Allais, F. Chemo-enzymatic preparation of new bio-based bis- and trisphenols: New versatile building blocks for polymer chemistry. RSC Adv. 2013, 3, 8988-8997. [CrossRef]

127. Gioia, C.; Banella, M.B.; Vannini, M.; Celli, A.; Colonna, M.; Caretti, D. Resorcinol: A potentially bio-based building block for the preparation of sustainable polyesters. Eur. Polym. J. 2015, 73, 38-49. [CrossRef]

128. Nouailhas, H.; Aouf, C.; Le Guerneve, C.; Caillol, S.; Boutevin, B.; Fulcrand, H. Synthesis and properties of biobased epoxy resins. part 1: Glycidylation of flavonoids by epichlorohydrin. J. Polym. Sci. Part A Polym. Chem. 2011, 49, 2261-2270. [CrossRef]

129. Cupples, A.L.; Lee, H.; Stoffey, D.G. Design and synthesis of epoxy resins for rapid room temperature cures with primary amines in small masses. Advan. Chem. Ser. 1970, 92, 173-207.

130. Dumas, L.; Bonnaud, L.; Olivier, M.; Poorteman, M.; Dubois, P. High performance bio-based benzoxazine networks from resorcinol and hydroquinone. Eur. Polym. J. 2016, 75, 486-494. [CrossRef]

131. Hu, F.; La Scala, J.J.; Sadler, J.M.; Palmese, G.R. Synthesis and Characterization of Thermosetting Furan-Based Epoxy Systems. Macromolecules 2014, 47, 3332-3342. [CrossRef]

132. Deng, J.; Liu, X.; Li, C.; Jiang, Y.; Zhu, J. Synthesis and properties of a bio-based epoxy resin from 2,5-furandicarboxylic acid (FDCA). RSC Adv. 2015, 5, 15930-15939. [CrossRef]

133. Smith, P.B. Bio-based sources for terephthalic acid. ACS Symp. Ser. 2015, 1192, 453-469.

134. You, Z.; Bi, X.; Wang, Y. Fine Control of Polyester Properties via Epoxide ROP Using Monomers Carrying Diverse Functional Groups. Macromol. Biosci. 2012, 12, 822-829. [CrossRef] [PubMed]

135. Fache, M.; Auvergne, R.; Boutevin, B.; Caillol, S. New vanillin-derived diepoxy monomers for the synthesis of biobased thermosets. Eur. Polym. J. 2015, 67, 527-538. [CrossRef]

136. Parsell, T.; Yohe, S.; Degenstein, J.; Jarrell, T.; Klein, I.; Gencer, E.; Hewetson, B.; Hurt, M.; Kim, J.I.; Choudhari, H.; et al. A synergistic biorefinery based on catalytic conversion of lignin prior to cellulose starting from lignocellulosic biomass. Green Chem. 2015, 17, 1492-1499. [CrossRef]

137. Parsell, T.H.; Owen, B.C.; Klein, I.; Jarrell, T.M.; Marcum, C.L.; Haupert, L.J.; Amundson, L.M.; Kenttaemaa, H.I.; Ribeiro, F.; Miller, J.T.; et al. Cleavage and hydrodeoxygenation (HDO) of C-O bonds relevant to lignin conversion using Pd/Zn synergistic catalysis. Chem. Sci. 2013, 4, 806-813. [CrossRef]

138. Zhao, S.; Abu-Omar, M.M. Biobased Epoxy Nanocomposites Derived from Lignin-Based Monomers. Biomacromolecules 2015, 16, 2025-2031. [CrossRef] [PubMed]

139. Liu, X.; Zhang, J. High-performance biobased epoxy derived from rosin. Polym. Int. 2010, 59, $607-609$. [CrossRef]

140. Menard, R.; Negrell, C.; Ferry, L.; Sonnier, R.; David, G. Synthesis of biobased phosphorus-containing flame retardants for epoxy thermosets comparison of additive and reactive approaches. Polym. Degrad. Stab. 2015, 120, 300-312. [CrossRef]

141. Cornille, A.; Froidevaux, V.; Negrell, C.; Caillol, S.; Boutevin, B. Thiol-ene coupling: An efficient tool for the synthesis of new biobased aliphatic amines for epoxy curing. Polymer 2014, 55, 5561-5570. [CrossRef]

142. Menard, R.; Negrell, C.; Fache, M.; Ferry, L.; Sonnier, R.; David, G. From a bio-based phosphorus-containing epoxy monomer to fully bio-based flame-retardant thermosets. RSC Adv. 2015, 5, 70856-70867. [CrossRef]

143. Jannesari, A.; Ghaffarian, S.R.; Molaei, A. The effect of curing reaction on mesophase-rich islands of segmented main chain liquid crystalline oligoesters. React. Funct. Polym. 2006, 66, 1250-1262. [CrossRef]

144. Noordover, B.A.J.; Heise, A.; Malanowksi, P.; Senatore, D.; Mak, M.; Molhoek, L.; Duchateau, R.; Koning, C.E.; van Benthem, R.A.T.M. Biobased step-growth polymers in powder coating applications. Prog. Org. Coat. 2009, 65, 187-196. [CrossRef]

145. Cao, L.; Liu, X.; Na, H.; Wu, Y.; Zheng, W.; Zhu, J. How a bio-based epoxy monomer enhanced the properties of diglycidyl ether of bisphenol A (DGEBA)/graphene composites. J. Mater. Chem. A 2013, 1, 5081-5088. [CrossRef] 
146. Chen, S.; Lv, S.; Hou, G.; Huo, L.; Gao, J. Mechanical and thermal properties of biphenyldiol formaldehyde resin/gallic acid epoxy composites enhanced by graphene oxide. J. Appl. Polym. Sci. 2015, 132, 42637. [CrossRef]

147. Tomita, H.; Yonezawa, K. Epoxy Resin and Process for Preparing the Same. U.S. 19854540802, 1985.

148. Fache, M.; Monteremal, C.; Boutevin, B.; Caillol, S. Amine hardeners and epoxy cross-linker from aromatic renewable resources. Eur. Polym. J. 2015, 73, 344-362. [CrossRef]

149. Hu, F.; Sharifi, M.; Palmese, G. Influence of Furanyl Building Blocks on the Cure Kinetics of a Renewable Epoxy-Amine System. In Green Polymer Chemistry: Biobased Materials and Biocatalysis; American Chemical Society: Washington, DC, USA, 2015; Volume 1192, pp. 387-399.

150. Hu, F.; La Scala, J.J.; Sadler, J.M.; Palmese, G.R. Correction to Synthesis and Characterization of Thermosetting Furan-Based Epoxy Systems. Macromolecules 2016, 49, 2408. [CrossRef]

151. Hu, F.; Yadav, S.K.; La Scala, J.J.; Sadler, J.M.; Palmese, G.R. Preparation and Characterization of Fully Furan-Based Renewable Thermosetting Epoxy-Amine Systems. Macromol. Chem. Phys. 2015, 216, 1441-1446. [CrossRef]

152. Tian, Q.; Yuan, Y.C.; Rong, M.Z.; Zhang, M.Q. A thermally remendable epoxy resin. J. Mater. Chem. 2009, 19, 1289-1296. [CrossRef]

153. Liu, R.; Zhang, X.; Gao, S.; Liu, X.; Wang, Z.; Yan, J. Bio-based epoxy-anhydride thermosets from six-armed linoleic acid-derived epoxy resin. RSC Adv. 2016, 6, 52549-52555. [CrossRef]

154. Huang, X.-S.; Qing, F.-L. Synthesis of novel poly(hydroxyether terephthalate) via polyaddition of 2,5-difluoroterephthalic acid with aromatic bis(epoxide)s. J. Fluorine Chem. 2008, 129, 1076-1082. [CrossRef]

155. Grelier, S.; Cramail, H.; Llevot, A.; Carlotti, S.; Grau, E. New Phenolic Monomers for Preparation of Various Polymers. WO2016050989A1, 7 April 2016.

156. Grelier, S.; Cramail, H.; Llevot, A.; Carlotti, S.; Grau, E. Chemoenzymic Preparation of Biphenyl Compounds Using Laccase as a Coupling Catalyst. WO2016050988A1, 7 April 2016.

157. Maiorana, A.; Spinella, S.; Gross, R.A. Bio-Based Alternative to the Diglycidyl Ether of Bisphenol A with Controlled Materials Properties. Biomacromolecules 2015, 16, 1021-1031. [CrossRef] [PubMed]

158. Badarinarayana, V.; Rodwogin, M.D.; Mullen, B.D.; Purtle, I.; Molitor, E.J. Processes to Prepare Levulinic Acid, Formic Acid and/or Hydroxymethyl Furfural from Various Biomass Materials. WO2014189991A1, 5 May 2016.

159. Liu, Z.; Zhang, G.; Sun, H.; Jiang, H.; Zhao, C.; Xu, D.; Li, H.; Sun, X.; Na, H. Preparation, characterization and thermal properties of tetramethylbisphenol F epoxy resin and mixed systems. Polym. Int. 2012, 61, 565-570. [CrossRef]

160. Meylemans, H.A.; Groshens, T.J.; Harvey, B.G. Synthesis of Renewable Bisphenols from Creosol. ChemSusChem 2012, 5, 206-210. [CrossRef] [PubMed]

161. Duann, Y.-F.; Liu, T.-M.; Cheng, K.-C.; Su, W.F. Thermal stability of some naphthalene- and phenyl-based epoxy resins. Polym. Degrad. Stab. 2004, 84, 305-310. [CrossRef]

162. Foyer, G.; Chanfi, B.-H.; Virieux, D.; David, G.; Caillol, S. Aromatic dialdehyde precursors from lignin derivatives for the synthesis of formaldehyde-free and high char yield phenolic resins. Eur. Polym. J. 2016, 77, 65-74. [CrossRef]

163. Ng, W.O.; Watanabe, S.; Humphreys, R.W.R.; Slater, S.C. Biological Synthesis of $p$-Aminobenzoic Acid, p-Aminophenol, n-(4-Hydroxyphenyl)Ethanamide and Derivatives Thereof. WO2013103894A1, 11 July 2013.

164. Harvey, B.G.; Guenthner, A.J.; Meylemans, H.A.; Haines, S.R.L.; Lamison, K.R.; Groshens, T.J.; Cambrea, L.R.; Davis, M.C.; Lai, W.W. Renewable thermosetting resins and thermoplastics from vanillin. Green Chem. 2015, 17, 1249-1258. [CrossRef]

165. Zou, Q.; Ba, L.; Tan, X.; Tu, M.; Cheng, J.; Zhang, J. Tunable shape memory properties of rigid-flexible epoxy networks. J. Mater. Sci. 2016, 51, 10596-10607. [CrossRef]

166. Menard, R.; Caillol, S.; Allais, F. Ferulic acid-based renewable esters and amides-containing epoxy thermosets from wheat bran and beetroot pulp: Chemo-enzymatic synthesis and thermo-mechanical properties characterization. Ind. Crops Prod. 2017, 95, 83-95. [CrossRef]

167. Fourcade, D.; Ritter, B.S.; Walter, P.; Schönfeld, R.; Mülhaupt, R. Renewable resource-based epoxy resins derived from multifunctional poly(4-hydroxybenzoates). Green Chem. 2013, 15, 910-918. [CrossRef] 
168. Debuissy, T.; Pollet, E.; Averous, L. Synthesis of potentially biobased copolyesters based on adipic acid and butanediols: Kinetic study between 1,4- and 2,3-butanediol and their influence on crystallization and thermal properties. Polymer 2016, 99, 204-213. [CrossRef]

169. Ventura, S.P.M.; de Morais, P.; Coelho, J.A.S.; Sintra, T.; Coutinho, J.A.P.; Afonso, C.A.M. Evaluating the toxicity of biomass derived platform chemicals. Green Chem. 2016, 18, 4733-4742. [CrossRef]

170. Fache, M.; Boutevin, B.; Caillol, S. Vanillin, a key-intermediate of biobased polymers. Eur. Polym. J. 2015, 68, 488-502. [CrossRef]

171. Fache, M.; Boutevin, B.; Caillol, S. Vanillin Production from Lignin and Its Use as a Renewable Chemical. ACS Sustain. Chem. Eng. 2016, 4, 35-46. [CrossRef]

172. Koike, T. Progress in development of epoxy resin systems based on wood biomass in Japan. Polym. Eng. Sci. 2012, 52, 701-717. [CrossRef]

173. Ochi, M.; Zhu, S.; Shimbo, M. Mechanical relaxation properties of spiro-type epoxide resins cured with acid anhydrides. Polymer 1986, 27, 1569-1573. [CrossRef]

174. Rao, V.S.; Samui, A.B. Molecular engineering of photoactive liquid crystalline polyester epoxies containing benzylidene moiety. J. Polym. Sci. Part A Polym. Chem. 2008, 46, 7637-7655. [CrossRef]

175. Cheng, J.; Chen, J.; Yang, W.T. Synthesis and characterization of novel multifunctional epoxy resin. Chin. Chem. Lett. 2007, 18, 469-472. [CrossRef]

176. Aouf, C.; Benyahya, S.; Esnouf, A.; Caillol, S.; Boutevin, B.; Fulcrand, H. Tara tannins as phenolic precursors of thermosetting epoxy resins. Eur. Polym. J. 2014, 55, 186-198. [CrossRef]

177. Nouailhas, H.; Burguiere, C.; Caillol, S.; Boutevin, B.; Fulcrand, H.; Rapior, S. Novel Method for Producing Thermosetting Epoxy Resins. FR2946049A1, 3 December 2010.

178. Over, L.C.; Meier, M.A.R. Sustainable allylation of organosolv lignin with diallyl carbonate and detailed structural characterization of modified lignin. Green Chem. 2015, 18, 197-207. [CrossRef]

179. Gandini, A.; Belgacem, M.N.; Guo, Z.-X.; Montanari, S. Lignins as Macromonomers for Polyesters and Polyurethanes. In Chemical Modification, Properties, and Usage of Lignin; Hu, T.Q., Ed.; Springer: Berlin, Germany, 2002; pp. 57-80.

180. Gibbons, L.; Smith, M.; Quirino, R.L. Modified lignin for composite and pellet binder applications. Int. J. Exp. Comput. Biomech. 2015, 3, 200-217. [CrossRef]

181. Effendi, A.; Gerhauser, H.; Bridgwater, A.V. Production of renewable phenolic resins by thermochemical conversion of biomass: A review. Renew. Sustain. Energy Rev. 2008, 12, 2092-2116. [CrossRef]

182. Sadeghifar, H.; Cui, C.; Argyropoulos, D.S. Toward Thermoplastic Lignin Polymers. Part 1. Selective Masking of Phenolic Hydroxyl Groups in Kraft Lignins via Methylation and Oxypropylation Chemistries. Ind. Eng. Chem. Res. 2012, 51, 16713-16720. [CrossRef]

183. Silva, E.A.B.D.; Zabkova, M.; Araújo, J.D.; Cateto, C.A.; Barreiro, M.F.; Belgacem, M.N.; Rodrigues, A.E. An integrated process to produce vanillin and lignin-based polyurethanes from Kraft lignin. Chem. Eng. Res. Des. 2009, 87, 1276-1292. [CrossRef]

184. Wu, L.C.F.; Glasser, W.G. Engineering plastics from lignin. I. Synthesis of hydroxypropyl lignin. J. Appl. Polym. Sci. 1984, 29, 1111-1123. [CrossRef]

185. Fache, M.; Boutevin, B.; Caillol, S. Epoxy thermosets from model mixtures of the lignin-to-vanillin process. Green Chem. 2016, 18, 712-725. [CrossRef]

186. Ferdosian, F.; Yuan, Z.; Anderson, M.; Xu, C. Sustainable lignin-based epoxy resins cured with aromatic and aliphatic amine curing agents: Curing kinetics and thermal properties. Thermochim. Acta 2015, 618, 48-55. [CrossRef]

187. Zhao, B.; Chen, G.; Liu, Y.; Hu, K.; Wu, R. Synthesis of lignin base epoxy resin and its characterization. J. Mater. Sci. Lett. 2001, 20, 859-862. [CrossRef]

188. Sun, G.; Sun, H.; Liu, Y.; Zhao, B.; Zhu, N.; Hu, K. Comparative study on the curing kinetics and mechanism of a lignin-based-epoxy/anhydride resin system. Polymer 2007, 48, 330-337. [CrossRef]

189. Kaiho, A.; Mazzarella, D.; Satake, M.; Kogo, M.; Sakai, R.; Watanabe, T. Construction of di(trimethylolpropane) cross linkage and phenylnaphthalene structure coupled with selective $\beta-O-4$ bond cleavage for synthesizing lignin-based epoxy resins with controlled glass transition temperature. Green Chem. 2016. Ahead of Print.

190. Asada, C.; Basnet, S.; Otsuka, M.; Sasaki, C.; Nakamura, Y. Epoxy resin synthesis using low molecular weight lignin separated from various lignocellulosic materials. Int. J. Biol. Macromol. 2015, 74, 413-419. [CrossRef] [PubMed] 
191. Fang, R.; Cheng, X.-S.; Lin, W.-S. Preparation and application of Dimer acid/lignin graft copolymer. BioResources 2011, 6, 2874-2884.

192. Engelmann, G.; Ganster, J. Bio-based epoxy resins with low molecular weight kraft lignin and pyrogallol. Holzforschung 2014, 68, 435-446. [CrossRef]

193. Benyahya, S.; Aouf, C.; Caillol, S.; Boutevin, B.; Pascault, J.P.; Fulcrand, H. Functionalized green tea tannins as phenolic prepolymers for bio-based epoxy resins. Ind. Crops Prod. 2014, 53, 296-307. [CrossRef]

194. Jahanshahi, S.; Pizzi, A.; Abdulkhani, A.; Shakeri, A. Analysis and Testing of Bisphenol A-Free Bio-based Tannin Epoxy-Acrylic Adhesives. Polymers 2016, 8. [CrossRef]

195. Jahanshahi, S.; Pizzi, A.; Abdulkhani, A.; Doosthoseini, K.; Shakeri, A.; Lagel, M.C.; Delmotte, L. MALDI-TOF, ${ }^{13} \mathrm{C}-\mathrm{NMR}$ and FT-MIR analysis and strength characterization of glycidyl ether tannin epoxy resins. Ind. Crops Prod. 2016, 83, 177-185. [CrossRef]

196. Jaillet, F.; Darroman, E.; Ratsimihety, A.; Auvergne, R.; Boutevin, B.; Caillol, S. New biobased epoxy materials from cardanol. Eur. J. Lipid Sci. Technol. 2014, 116, 63-73. [CrossRef]

197. Cornille, A.; Serres, J.; Michaud, G.; Simon, F.; Fouquay, S.; Boutevin, B.; Caillol, S. Syntheses of epoxyurethane polymers from isocyanate free oligo-polyhydroxyurethane. Eur. Polym. J. 2016, 75, 175-189. [CrossRef]

198. Darroman, E.; Durand, N.; Boutevin, B.; Caillol, S. Improved cardanol derived epoxy coatings. Prog. Org. Coat. 2016, 91, 9-16. [CrossRef]

199. Dworakowska, S.; Cornille, A.; Bogdal, D.; Boutevin, B.; Caillol, S. Formulation of bio-based epoxy foams from epoxidized cardanol and vegetable oil amine. Eur. J. Lipid Sci. Technol. 2015, 117, 1893-1902. [CrossRef]

200. Can, E.; Kınac1, E.; Palmese, G.R. Preparation and characterization of novel vinyl ester formulations derived from cardanol. Eur. Polym. J. 2015, 72, 129-147. [CrossRef]

201. Jaillet, F.; Nouailhas, H.; Auvergne, R.; Ratsimihety, A.; Boutevin, B.; Caillol, S. Synthesis and characterization of novel vinylester prepolymers from cardanol. Eur. J. Lipid Sci. Technol. 2014, 116, 928-939. [CrossRef]

202. Wan, J.; Gan, B.; Li, C.; Molina-Aldareguia, J.; Kalali, E.N.; Wang, X.; Wang, D.-Y. A sustainable, eugenol-derived epoxy resin with high biobased content, modulus, hardness and low flammability: Synthesis, curing kinetics and structure-property relationship. Chem. Eng. J. 2016, 284, 1080-1093. [CrossRef]

203. Czub, P. Synthesis and modification of epoxy resins using recycled poly(ethylene terephthalate). Polym. Adv. Technol. 2009, 20, 183-193. [CrossRef]

204. Fuessl, A.; Yamamoto, M.; Schneller, A. Polymer Science: A Comprehensive Reference; Matyjaszewski, K., Möller, M., Eds.; Elsevier: Amsterdam, The Netherlands, 2012; Volume 5, pp. 49-70.

205. Chrysanthos, M.; Galy, J.; Pascault, J.-P. Influence of the Bio-Based Epoxy Prepolymer Structure on Network Properties. Macromol. Mater. Eng. 2013, 298, 1209-1219. [CrossRef]

206. Darroman, E.; Bonnot, L.; Auvergne, R.; Boutevin, B.; Caillol, S. New aromatic amine based on cardanol giving new biobased epoxy networks with cardanol. Eur. J. Lipid Sci. Technol. 2015, 117, 178-189. [CrossRef]

(C) 2017 by the authors; licensee MDPI, Basel, Switzerland. This article is an open access article distributed under the terms and conditions of the Creative Commons Attribution (CC-BY) license (http://creativecommons.org/licenses/by/4.0/). 